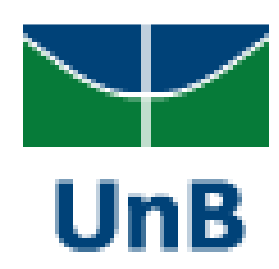

UNIVERSIDADE DE BRASÍLIA

CENTRO DE ESTUDOS AVANÇADOS MULTIDISCIPLINARES

Programa de Pós-Graduação em Desenvolvimento, Sociedade e

Cooperação Internacional

\title{
A EMBRAPA E A COOPERAÇÃO TÉCNICA INTERNACIONAL PARA O DESENVOLVIMENTO NA ÁFRICA SUBSAARIANA: \\ o caso do Projeto ProSavana
}

Adriana Milhomem Seixas Lombardo

Brasília, DF

Março de 2015 
UNIVERSIDADE DE BRASÍLIA

Centro de Estudos Avançados Multidisciplinares

Programa de Pós-Graduação em Desenvolvimento, Sociedade e

Cooperação Internacional

\title{
A EMBRAPA E A COOPERAÇÃO TÉCNICA INTERNACIONAL PARA O DESENVOLVIMENTO NA ÁFRICA SUBSAARIANA: \\ o caso do Projeto ProSavana
}

Adriana Milhomem Seixas Lombardo

\begin{abstract}
Dissertação apresentada ao Programa de Pós-Graduação em Desenvolvimento, Sociedade e Cooperação Internacional do Centro de Estudos Avançados Multidisciplinares da Universidade de Brasília, como requisito à obtenção do título de Mestre.

Área de concentração: Desenvolvimento, Sociedade e Cooperação Internacional

Linha de pesquisa: Desenvolvimento e Cooperação Internacional
\end{abstract}

Orientadora: Prof ${ }^{\underline{a}}{ }^{a}$ Ana Lúcia E. F. Valente 
LOMBARDO, Adriana Milhomem Seixas

A Embrapa e a Cooperação Técnica Internacional para o Desenvolvimento na África Subsaariana: O Caso do Projeto ProSavana/ Adriana Milhomem Seixas Lombardo - Distrito Federal, 2015.

$138 \mathrm{f}$.

Orientadora: Ana Lúcia E.F. Valente Dissertação de Mestrado - Universidade de Brasília. Programa de Pós-Graduação em Desenvolvimento, Sociedade e Cooperação Internacional.

1. Cooperação técnica internacional para o desenvolvimento. 2. Embrapa. 3. Projetos de cooperação técnica internacional - África Subsaariana. 4. Cooperação agrícola internacional - Moçambique. 5. Relações interculturais. I. Universidade de Brasília. Centro de Estudos Avançados Multidisciplinares. Programa de Pós-Graduação em Desenvolvimento, Sociedade e Cooperação Internacional. II. A Embrapa e a Cooperação Técnica Internacional para o Desenvolvimento na África Subsaariana: O Caso do Projeto ProSavana. 


\author{
UNIVERSIDADE DE BRASÍLIA \\ Centro de Estudos Avançados Multidisciplinares \\ Programa de Pós-Graduação em Desenvolvimento, Sociedade e \\ Cooperação Internacional
}

Adriana Milhomem Seixas Lombardo

\title{
A EMBRAPA E A COOPERAÇÃO TÉCNICA INTERNACIONAL PARA O DESENVOLVIMENTO NA ÁFRICA SUBSAARIANA: \\ o caso do Projeto ProSavana
}

\begin{abstract}
Dissertação apresentada ao Centro de Estudos Avançados Multidisciplinares como requisito para obtenção do grau de Mestre em Desenvolvimento, Sociedade e Cooperação Internacional.
\end{abstract}

Aprovada em 27 de março de 2015.

BANCA EXAMINADORA:

Prof $^{\mathrm{a}}{ }^{-}{ }^{\mathrm{a}} \stackrel{\mathrm{a}}{ }$ Ana Lúcia E.F. Valente

Programa de Pós-Graduação em Desenvolvimento, Sociedade e Cooperação Internacional/UnB

Prof $^{\mathrm{a}}$ Dr$^{\mathrm{a}}$ Kelly Cristiane da Silva

Departamento de Antropologia/UnB

Prof. Dr. José Walter Nunes

Programa de Pós-Graduação em Desenvolvimento, Sociedade e Cooperação Internacional/UnB

SUPLENTE: Prof $^{-a}$ Dr $^{a}$ Ana Maria Nogales

Programa de Pós-Graduação em Desenvolvimento, Sociedade e Cooperação Internacional/UnB 
"Ottittimihana Muluku orooruuha, anaphulu anniteexana ehírowaka otthu".

O respeito vem de Deus;

até os sapos carregam-se um ao outro às costas sem irem a lado algum.

(Provérbio Macua) 
Ao meu marido Massimiliano Lombardo, grande incentivador desta pesquisa, e ao meu filho Luigi, pelo amor, alegria e temperança. 


\section{AGRADECIMENTOS}

Agradeço a todos que me estimularam a desenvolver e concretizar o meu trabalho de pesquisa.

Em especial, aos meus pais, pelo amor, apoio e confiança; e meus irmãos pelo companheirismo.

À professora Dra. Ana Lúcia, minha orientadora, por ter aceitado me acompanhar nessa jornada, pelo estímulo à leitura e ao meu aperfeiçoamento acadêmico.

Agradeço ao Programa de Pós-Graduação em Desenvolvimento, Sociedade e Cooperação Internacional, professores e equipe técnica, em especial a Professora Ana Maria Nogales, por sua dedicação como Coordenadora, a Professora Viviane de Melo Resende por compartilhar seus conhecimentos na disciplina Análise do Discurso e os professores José Walter Nunes e Nancy Alessio (in memorian) por sua generosidade em transmitir, de forma inspiradora, suas vivências na disciplina Cultura, Memória e Globalização.

Agradeço a minha banca de qualificação, que superou minhas expectativas por suas demonstrações de profissionalismo, comprometimento com a pesquisa e profundo envolvimento com a Universidade de Brasília. Reafirmo meus agradecimentos à professora do Departamento de Antropologia, Dra. Kelly Silva, por seus direcionamentos.

Aos colegas do PPGDSCI, principalmente Floriano Filho, por seu senso crítico e uma amizade que ficará para sempre; Ângela Pires Terto, pelos aconselhamentos técnicos e o apoio moral; Mônica Figueiredo Duarte, Maria do Carmo dos Santos, Valéria Graziano e Rubenilson Cerqueira, por compartilharem as experiências de quem já vivenciou e finalizou com êxito esse processo.

Aos meus chefes da Embrapa, Dr. Paulo Eduardo de Melo e Dr. Elísio Contini; por suas demonstrações de confiança e estímulo ao meu desenvolvimento profissional; ao Dr. Otavio Balsadi por compartilhar seus textos e seu conhecimento em ricos debates.

Aos chefes da Secretaria de Relações Exteriores, Dr. Márcio Porto, Dr. Mário Seixas e ao coordenador Dr. André Dusi, pela abertura para que eu pudesse ter acesso aos estudos e reuniões sobre o projeto ProSavana. Sem seu apoio esse trabalho não poderia ter sido realizado.

Aos colegas da Embrapa, em destaque, Alberto Santana, pelos valiosos ensinamentos; Henoque Silva, por compartilhar suas vivências em Moçambique e me aproximar daquele dia-a-dia afastado; José Luiz Bellini, pelo estímulo à investigação. Agradeço, ainda, aos colegas: Alessandra Rodrigues, Dejoel de Barros Lima e Maria Consolacion Udry, por transmitirem suas experiências e leituras, em gestos de profunda amizade, enquanto minha mente estava inquieta, insaciável por 
aprender; Augusto Clemente, Caroline Turazi, Fernando Hello, Kilvia Craveiro e Tallyrand Moreira por seus gestos de afeto e aconselhamentos ponderados, ao longo do estudo.

Agradeço aos entrevistados pelo apoio ao fornecerem informações relativas ao projeto estudado, que, gentilmente, cederam o seu tempo e falaram sobre o projeto com entusiasmo e confiança. Seus nomes não serão citados, mas registro meu reconhecimento por sua contribuição.

Por último agradeço meu marido, por ter abdicado muitas vezes de suas horas de descanso para que eu pudesse realizar um sonho antigo e importante, por seus gestos de amor e apoio incondicional. Ao meu filho Luigi, por ter me ajudado a transformar momentos de tensão em brincadeira, risadas e muito carinho. Ao meu segundo filho que vive no meu ventre e que oferece amor e apoio ao seu modo, enquanto o carrego para todos os lados e vive comigo um mundo de emoções. Agradeço, sobretudo, a Deus, pela força e energia renovada a cada amanhecer. 


\section{RESUMO}

A presente dissertação analisa a influência das relações interculturais na Cooperação Técnica entre Países em Desenvolvimento (CTPD), em particular do Brasil com países africanos no âmbito da agricultura, focando em projetos gerenciados pela Empresa Brasileira de Pesquisa Agropecuária (Embrapa), vinculada ao Ministério de Agricultura, Pecuária e Abastecimento (MAPA). O objetivo principal do estudo é analisar em que medida a aplicação de um enfoque cultural pode auxiliar o desenvolvimento das iniciativas de cooperação técnica oficial entre o Brasil e outros países, promovendo a valorização das diferenças culturais e gerando benefícios mútuos. Para tal fim, será analisado um dos grandes projetos de cooperação da Embrapa ("Projetos Estruturantes"): o ProSavana, realizado em Moçambique. Tem-se como hipótese geral que os projetos não tenham devidamente considerado as dimensões culturais envolvidas na sua implementação. Depois de confirmar esta hipótese, o estudo irá apontar como projetos similares poderão incluir processos específicos de gerenciamento efetivo de relações interculturais entre Brasil e outros países, de acordo com o objetivo principal da CTPD de compartilhar conhecimentos, técnicas e tecnologias previamente testadas e validadas, adaptando-as de forma proveitosa para os países beneficiários. Metodologicamente, a pesquisa é sustentada pelos recursos teóricos e técnicos próprios da antropologia, por ser a ciência que acumulou uma ampla gama de conhecimento sobre a temática das diferenças sociais e culturais. Em razão disso, serão utilizados vários procedimentos (observação, entrevistas semiestruturadas e análise de discurso, entre outros) que têm enfoque qualitativo e múltiplo.

Palavras-chave: Agricultura; África; Brasil; Cooperação Técnica entre Países em Desenvolvimento. 


\begin{abstract}
This dissertation analyses the influence of intercultural relations on Technical Cooperation among Developing Countries (TCDC), specifically regarding Brazil with African countries in the field of agriculture, focusing on projects managed by the Brazilian Agricultural Research Corporation (Embrapa), affiliated to the Ministry of Agriculture, Livestock and Supply (MAPA). The main objective of the study is to analyse to what extent the implementation of a cultural approach can assist the development of official technical cooperation initiatives between Brazil and other countries, promoting the recognition of cultural differences and thus generating mutual benefits. To this end, one of the major cooperation projects of Embrapa ("Structuring Projects") will be analysed: the ProSavana, carried out in Mozambique. The overarching hypothesis is that those projects have not properly considered the cultural dimensions involved in its implementation. After confirming this hypothesis, the study will point out how similar projects could include specific procedures for the effective management of intercultural relations between Brazil and other countries, according to the main objective of TCDC to share knowledge, techniques and technologies which are previously tested and validated, usefully adapting them for the beneficiary countries. In terms of methodology, the research is supported by theoretical and technical resources normally used in anthropology, being this a science field which accumulated an extensive breadth of knowledge on the subject of social and cultural differences. For this reason, several procedures (observation, semi-structured interviews, and critical discourse analysis, among others), which have multiple and qualitative approach, will be used.
\end{abstract}

Keywords: Agriculture; Africa; Brazil; Technical Cooperation among Developing Countries. 


\section{LISTA DE ABREVIATURAS E SIGLAS}

$\mathrm{ABC}$

AOD

BCA

BID

BIRD

BRICS

C-4

CECAT

CNS

CSS

CTPD

CIAT

CIBA

CID

CIIAT

CIRAD

COBRADI

CRUE

DFID

DGP

DTT

EMBRAPA

ENAP

FAO

FAPESP

FASE
Agência Brasileira de Cooperação

Assistência Oficial para o Desenvolvimento

Boletim de Comunicações Administrativas

Banco Interamericano de Desenvolvimento

Banco Internacional para Reconstrução e Desenvolvimento

Brasil, Rússia, Índia, China e África do Sul

Cotton 4

Embrapa Estudos e Capacitação

Cooperação Norte-Sul

Cooperação Sul-Sul

Cooperação Técnica entre Países em Desenvolvimento

International Center for Tropical Agriculture (Centro Internacional de Agricultura Tropical)

Consórcio Internacional em Biologia Avançada

Cooperação Internacional para o Desenvolvimento

Centros Integrados de Investigação Agrária e Transferência de Tecnologia

Centre de coopération internationale en recherche agronomique pour le développement (Centro Francês de Cooperação Internacional em Pesquisa Agropecuária para o Desenvolvimento)

Cooperação Brasileira para o Desenvolvimento Internacional

Conferência dos Reitores das Universidades Espanholas

Department for International Development (Ministério do Reino Unido para o Desenvolvimento Internacional)

Departamento de Gestão de Pessoas

Departamento de Transferência de Tecnologia

Empresa Brasileira de Pesquisa Agropecuária

Escola Nacional de Administração Pública

Food and Agriculture Organization of the United Nations

(Organização das Nações Unidas para Alimentação e Agricultura)

Fundação de Amparo à Pesquisa do Estado de São Paulo

Federação de Órgãos para Assistência Social e Educacional 
Fundação Getúlio Vargas

FMI

Fundo Monetário Internacional

IBA

Instituto Brasileiro do Algodão

$\mathrm{IDH}$

Índice de Desenvolvimento Humano

IDE

Investimento Direto Estrangeiro

IDS

Institute of Development Studies (Instituto de Estudos sobre o

i.e. Desenvolvimento)

IER

isto é

IIAM

Instituto de Economia Rural

IICA

Instituto de Investigação Agrária de Moçambique

JBM

Instituto Interamericano de Cooperação para Agricultura

JICA

Japão, Brasil, Moçambique

Japan International Cooperation Agency

(Agência de Cooperação Internacional do Japão)

LABEX

Laboratórios Virtuais no Exterior

MAPA

MDA

Ministério da Agricultura, Pecuária e Abastecimento

MINAG

Ministério do Desenvolvimento Agrário

MRE

ONU

Ministério da Agricultura (de Moçambique)

Ministério das Relações Exteriores

Organização das Nações Unidas

ONG

Organização Não Governamental

PALOP

Países Africanos de Língua Portuguesa

PD

Plano Diretor

PDE

Plano Diretor da Embrapa

PD\&I

Pesquisa, Desenvolvimento e Inovação

PEDSA

Plano de Diretrizes para o Desenvolvimento da Agricultura

PEM

Projeto de Extensão e Modelos

PHD

Philosophy Doctor (corresponde ao título de Doutor no Brasil)

PI

Projeto de Investigação

PIAT

Plataforma de Inovação Agrária e Inovação Tecnológica

PIB

Produto Interno Bruto

PNISA

Plano Nacional de Investimentos para o Setor Agrário

PNUD

Programa das Nações Unidas para o Desenvolvimento

PO

Plano de Operação Conjunto

PROALIMENTOS Programas de Nutrição e Segurança Alimentar 
PRODECER Programa de Desenvolvimento dos Cerrados

PROSAVANA Programa de Cooperação Triangular para o Desenvolvimento Agrícola da Savana Tropical de Moçambique

PSAL Projeto de Apoio aos Programas de Segurança Alimentare Nutricional

PUC-Rio Pontifícia Universidade Católica do Rio de Janeiro

RCA

Resolução do Conselho de Administração

SNPA

Sistema Nacional de Pesquisa Agropecuária

SRI

Secretaria de Relações Internacionais

TCTP

Third Countries Training Program (Programa de Treinamento para Terceiros Países)

UD Unidade Descentralizada

UEM Universidade Eduardo Mondlane

UNAC União Nacional de Camponeses

UNB Universidade de Brasília

UP Universidade Pedagógica

USAID United States Agency for International Development (Agência dos Estados Unidos para o Desenvolvimento Internacional) 


\section{SUMÁRIO}

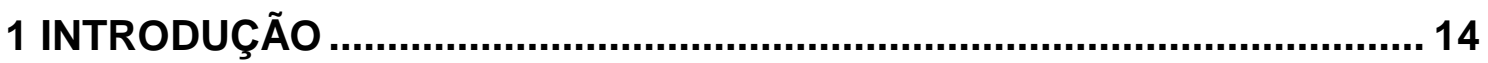

2 REFERENCIAIS EMPÍRICOS E TEÓRICOS.............................................. 21

2.1 DEFINIÇÃO DO PROBLEMA DE ESTUDO .................................................... 21

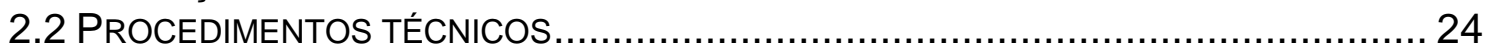

2.2.1 Pesquisa exploratória ou estudo preliminar..................................... 27

2.2.2 Pesquisa documental e bibliográfica .................................................. 27

2.2.3 Pesquisa Etnográfica Multissituada............................................. 28

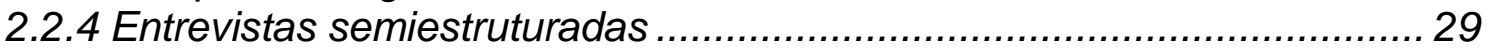

2.2.4 Entrevistas coletivas.............................................................. 31

2.2.5 A interação entre os procedimentos técnicos.................................... 32

3 OS REGISTROS HISTÓRICOS E O PASSADO DA EMBRAPA COM OLHOS DO

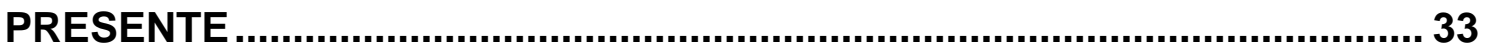

4 A EMBRAPA E OS PROJETOS DE COOPERAÇÃO TÉCNICA INTERNACIONAL 47

4.1 A TRAJETÓRIA DO BRASIL NA COOPERAÇÃO INTERNACIONAL PARA O DESENVOLVIMENTO

4.1.1 Conceituação e caracterização da CID, na perspectiva brasileira .......... 47

4.1.2 O surgimento da CTPD .............................................................. 50

4.1.3 Características atuais da CTPD brasileira....................................... 54

4.2 A TRAJETÓRIA DA EMBRAPA NA CTPD .............................................. 59

4.3 O CASO DO PROJETO PROSAVANA ................................................... 65

4.3.1 O Programa ProSavana - JBM e o milagre do cerrado ...........................66

4.3.2 Interpretações e especulações em torno dos investimentos estrangeiros71

4.3.4 O Projeto ProSavana - Pl: a participação da Embrapa em um cenário conflituoso ............................................................................................. 75

5 DISCURSO DA EMBRAPA E DISCURSO DOS COOPERANTES............... 80

5.1 DISCURSO INSTITUCIONAL .................................................................... 80

5.1.1 Embrapa: da difusão e transferência de tecnologia para a construção coletiva do conhecimento .................................................................................... 80

5.2 DISCURSO DOS COOPERANTES E ESPECIALISTAS ……................................ 84

5.2.1. A experiência de cooperação da Embrapa no projeto ProSavana frente aos

seus principais desafios ..................................................................... 84

5.2.2 A experiência de cooperação da Embrapa no projeto ProSavana frente às

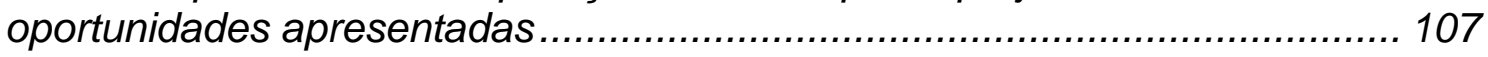

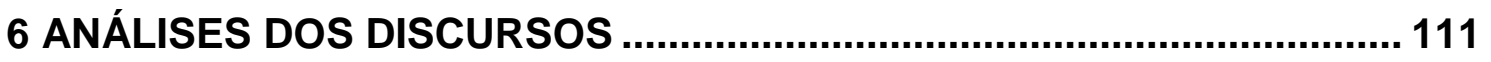

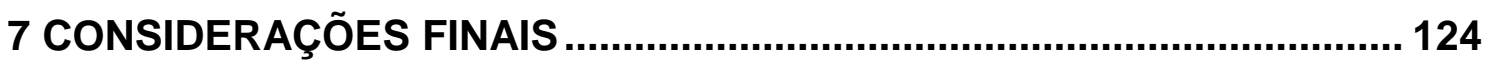

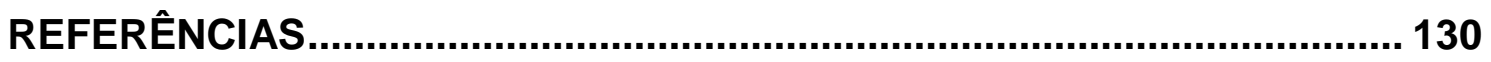




\section{INTRODUÇÃO}

A proposta desta dissertação é discutir o projeto ProSavana, realizado no Corredor de Nacala, em Moçambique e inserido no contexto da Cooperação Técnica entre Países em Desenvolvimento (CTPD) do Brasil com Japão e Moçambique, no âmbito da agricultura. Embora outros projetos de CTPD gerenciados pela Embrapa tenham sido estudados e sejam citados ao longo da dissertação, o ProSavana oferece condições para a compreensão de como se estabelecem as relações interculturais entre a Embrapa e as comunidades rurais da área delimitada pelo projeto, desde o ponto de vista dos cooperantes brasileiros envolvidos na execução do projeto e de publicações a seu respeito.

A iniciativa objeto desta análise é gerenciada pela Empresa Brasileira de Pesquisa Agropecuária (Embrapa), vinculada ao Ministério de Agricultura, Pecuária e Abastecimento (MAPA), órgão público criado pelo governo federal, em 26 de abril de 1973, tendo como missão "viabilizar soluções de pesquisa, desenvolvimento e inovação para a sustentabilidade da agricultura, em benefício da sociedade brasileira" (EMBRAPA, 2008). Na época, o desenvolvimento da agricultura era uma necessidade inquestionável, dada a urgência de atender à demanda progressiva de alimentos. Assim, a criação da Embrapa atendia às ambições daquele governo que, na iminente crise mundial do mercado do petróleo, esperava ampliar a disponibilidade de commodities agrícolas, então limitadas ao café, açúcar, cacau e algodão. Hoje, depois de 42 anos de existência, a Embrapa tem um legado de ações que elevaram a participação do Brasil ao patamar de um dos maiores produtores e exportadores mundiais de alimentos. Nesse longo intervalo, à medida que o Brasil evoluiu seu papel no contexto político e econômico global, a Empresa aumentou sua atuação internacional, participando em um crescente número de iniciativas de cooperação do governo brasileiro.

A partir do final dos anos setenta, o Brasil tem expandido sua participação em iniciativas de CTPD, também denominada Cooperação Sul-Sul (CSS) ou Cooperação Horizontal. Sem deixar de ser receptor, o Brasil passou a contribuir de forma incipiente, mas progressiva, como provedor de cooperação técnica para outros países menos desenvolvidos. Nesse sentido, o volume de CTPD do Brasil, nos últimos anos, projetou o país no cenário internacional e à condição de global 
player. A partir desse contexto, a Embrapa passou a ser chamada, cada vez mais, a atender as demandas de cooperação no setor da agricultura, advindas da política externa do Governo Federal, definidas pelo Ministério das Relações Exteriores (MRE).

No âmbito da agricultura, o conhecimento da delimitação geográfica e as afinidades climáticas e de solo são fundamentais para gerar uma parceria. Desse modo, as ações internacionais do Brasil estão concentradas principalmente em países da América Latina e da África. No campo sociocultural, embora as motivações culturais sejam citadas como importantes para o estabelecimento de uma relação de cooperação, normalmente não são devidamente consideradas no desenho dos projetos e tampouco em sua execução.

O discurso político nacional apregoa a vontade de cooperar para o desenvolvimento da África Subsaariana, inclusive tendo como base a solidariedade. Por outro lado, observadores africanos desconfiam de algumas formas de ajuda, tanto de países desenvolvidos quanto de emergentes, pois consideram que esses estão mais interessados em explorar as riquezas naturais do continente. Sugerem, ainda, que no bloco dos emergentes, alguns países têm, ao contrário de um discurso de compaixão, interesse em ter acesso aos seus mercados com milhões de consumidores, buscando satisfazer suas necessidades de crescimento interno e poder no contexto internacional (BADI, 2009).

Os africanos, hoje, desconfiam que o modelo de cooperação praticado por esses países seja bem diferente daquele defendido no surgimento da Cooperação Sul Sul (CSS), que apregoava o fortalecimento da economia, o desenvolvimento social e a liberação das nações do colonialismo. Segundo esses observadores, a CSS pode disfarçar formas antigas de colonialismo, agora praticadas com uma diferente abordagem. Além disso, existe a preocupação recorrente que o continente se torne centro de tensões, disputas políticas e geopolíticas e de rivalidades que desestabilizem os estados africanos mais frágeis (BADI, 2009).

De acordo com Bhabha,

[...] os embates de fronteira acerca de diferença cultural têm tanta possibilidade de serem consensuais quanto conflituosos; podem confundir nossas definições de tradição e modernidade, realinhar as fronteiras habituais entre o público e o privado, o alto e o baixo, assim como desafiar as expectativas normativas de desenvolvimento e progresso (BHABHA, 1998, p. 21). 
Esse conceito tem relevância no âmbito específico da CTPD, tema central desta pesquisa, no qual deveria ser imperativo levar em consideração as diferenças culturais dos países envolvidos, antes de se estabelecer uma relação concreta de trabalho entre eles. Isto porque tal preocupação ou estratégia poderia diminuir a probabilidade de geração de conflitos e minimizar insucessos causados pela execução de planos resultantes apenas de normas e princípios pré-estabelecidos com base nas suposições e expectativas das entidades provedoras de cooperação.

As opiniões sobre a África, de modo geral, são bastante divergentes. Um quadro foi pintado como se o continente estivesse destinado ao subdesenvolvimento. Suas poucas perspectivas econômicas e sociais derivariam de problemas relacionados com características históricas, climáticas, geográficas, antropológicas e culturais.Doenças tropicais que afetaram seu povo,e elevada corrupção são argumentos reais utilizados para comprovar essa teoria. Dessa maneira, é fortalecido o mito segundo o qual a África só conseguiria avançar com o apoio de ajuda externa (CHANG, 2013; MOYO, 2009). No entanto, o continente teve em sua história períodos de crescimento. A causa da estagnação nas últimas três décadas pode estar associada às políticas de livre mercado que vários países do continente foram obrigados a adotar no contexto da globalização. No entanto, esses países agora têm maior capacidade e autonomia para mudar essas políticas (CHANG, 2013).

A partir de uma análise mais ampla, torna-se perceptível a saturação de abordagens conservadoras e autoritárias no que tange as relações internacionais. Um conjunto de regras, normas e até mesmo de tecnologias é insuficiente para gerar uma verdadeira cooperação. Vários países africanos estão interessados em obter tecnologias brasileiras, mas o desafio está em garantir que sua utilização beneficie a sociedade como um todo. Nesse sentido, ao facilitar o compartilhamento de conhecimentos, tecnologias e recursos entre países, a cooperação para o desenvolvimento pode promover o crescimento sustentável. Corroborando com essa colocação, Côrrea afirma que

A cooperação para o desenvolvimento atua como um instrumento capaz de alterar e elevar níveis de vida, promover o crescimento sustentável e contribuir para o desenvolvimento social. Em um mundo de agudas desigualdades e assimetrias de toda ordem, com particular ênfase para os alarmantes índices de pobreza e de fome, a cooperação internacional revela-se um instrumento indispensável e mesmo irrecusável para que nações compartilhem de seus conhecimentos, recursos e capacidades no 
sentido de catalisar processos de desenvolvimento no limite de suas possibilidades (CÔRREA, 2010, p. 235).

Respeitando as peculiaridades de cada país, várias instituições do Governo Brasileiro investem em programas e projetos que favorecem transferência de tecnologia e de conhecimentos e o desenvolvimento de capacidades individuais e institucionais. Tais ações são voltadas, principalmente, para países da América Latina e Caribe, África e Ásia (CAMPOS, 2007).

Moçambique, país da África Subsaariana escolhido para implantação do Projeto ProSavana, teve colonização portuguesa e faz parte dos cinco países lusófonos da África, também conhecidos pela abreviação PALOP (Países Africanos de Língua Oficial Portuguesa) i.e. Angola, Cabo Verde, Guiné-Bissau, Moçambique e São Tomé e Príncipe. Dentre os PALOP, Moçambique está entre os principais destinatários da cooperação técnica brasileira. Sua proximidade e a relação econômica periférica com a África do Sul, atualmente incluída nos BRICS, afetam de forma positiva e negativa o seu desenvolvimento. O regime sul-africano do apartheid não somente estrangulou economicamente o país, como desestabilizou suas infraestruturas, intensificada por uma queda nas exportações tradicionais.

$\mathrm{Na}$ última década, Moçambique passou por uma fase de intenso crescimento econômico (cerca de 7\% ao ano). A contribuição do setor da agricultura tem sido importante (quase $30 \%$ do total), ainda mais considerando que ocupa mais de $70 \%$ da população economicamente ativa. A perspectiva é de continuação do considerável investimento direto estrangeiro (IDE), aumento da produção de carvão, expansão do crédito ao setor privado e forte investimento em infraestruturas, que tenderão a impulsionar o crescimento para $8.5 \%$ e $8.0 \%$ em 2013 e 2014, respectivamente (BID; OCDE, 2013). Entretanto, a dependência da ajuda externa continua significativa (OSMAN; SAÚTE, 2010).

Segundo o Programa das Nações Unidas para o Desenvolvimento (PNUD), Moçambique está na posição 178 entre os 187 países do mundo avaliados em termos de Índice de Desenvolvimento Humano (IDH). Portanto, seu impressionante crescimento econômico na última década não se traduziu em redução da pobreza e da desigualdade (PNUD, 2015). Cerca de $60 \%$ da sua população vive abaixo da linha internacional da pobreza (i.e. renda equivalente a um dólar americano/dia). As crianças, principalmente das áreas rurais, não têm oportunidades educacionais e os índices de má-nutrição apavoram. A continuação da tendência negativa registrada 
nos fluxos de ajuda externa irá afetar o equilíbrio orçamental. Espera-se um aumento do déficit para $9,2 \%$, em 2013 , e para $9.5 \%$, em 2014 , contra $8.2 \%$, em 2012. O Governo prevê recorrer ao financiamento privado e às parcerias públicoprivadas para financiar o desenvolvimento de infraestruturas. Torna-se necessário reforçar o enquadramento institucional a fim de garantir a prestação de contas e o acompanhamento dos projetos, além de adicionar valor econômico (BID; OCDE, 2013). Por outro lado, o país tem recebido ao longo dos anos tanto apoio externo que chega a ter acúmulo de investimento para o mesmo fim.

Ainda que seja perceptível a magnitude dos problemas em Moçambique e a carência de soluções em vários setores, tais fatores não podem servir de argumento para uma articulação isolada, sem a efetiva participação dos beneficiários. A comunidade local é capaz de refletir, de maneira profunda, sobre suas reais necessidades. Nesse sentido, o conhecimento das demandas e das expectativas das comunidades beneficiárias facilita a identificação de oportunidades de cooperação, tendo em vista que a parceria pressupõe vantagem para ambas às partes. Entretanto, modelos pré-formulados e soluções construídas externamente podem ter impactos negativos se não levarem em devida consideração os desafios e as oportunidades do país.

Moçambique viveu um longo período, 26 anos, em guerra. Sua sociedade civil congrega vários atores com motivações comuns e altruístas, mas também alguns que escondem interesses particulares. Jogos de poder não são restritos ao governo e às elites. A sociedade civil também "congrega vontades diferentes ou mesmo antagônicas, conflitos de interesse que entram em choque, percepções diferentes" (EMBRAPA, 2014a, p. 57).

Embora alguns documentos técnicos da Embrapa que regulam a implementação do ProSavana indicam preocupações de ordem socioeconômica, na implementação do Projeto não houve um estudo adequado das reais demandas da sociedade e dos principais impactos de uma execução que não conta com mecanismos e práticas de consulta e anuência da sociedade civil ou dos seus representantes. Sabe-se, por outro lado, que existe uma mediação das elites nacionais, realizada a partir do Governo Moçambicano e do Instituto de Investigação Agrária de Moçambique (IIAM), que pode não traduzir exatamente a visão da comunidade, seja por falta de profundidade na informação ou até a fim de garantir interesses particulares. Portanto, desconsiderar as relações de poder que 
atravessam governos e grupos sociais não ajudará a revelar os desafios da CTPD brasileira.

Visando gerar uma compreensão que possa tornar o processo mais efetivo, e favorecer a aprendizagem conjunta de todos os atores envolvidos, buscou-se, no âmbito desse projeto, ouvir as percepções dos atores envolvidos e identificar elementos que demonstrassem as expectativas, os valores culturais e as crenças, que, porventura, pudessem reduzir choques culturais e favorecer o intercâmbio entre Brasil e países africanos, sejam eles de origem portuguesa ou não. Afinal, segundo a Embrapa, "não se trata de transferir tecnologia e prestar assistência técnica simplesmente, mas de dialogar e somar competências para desenvolver estudos adaptativos de soluções já aplicadas no Brasil e pesquisas inovadoras de interesse comum" (EMBRAPA, 2011a, p. 1).

A dissertação está organizada da seguinte forma, para além desta Introdução: o capítulo "Referenciais Empíricos e Teóricos" explicitará os procedimentos técnicos utilizados para coleta, análise e consolidação dos dados da pesquisa.

O capítulo "Os registros históricos e o passado da Embrapa com olhos do presente" apresentará, a partir de documentos e memórias da Embrapa, a contextualização de seus modelos de atuação frente aos principais públicos. Da mesma forma, discorrerá do contexto histórico enquanto problematiza a discussão sobre transferência de tecnologia.

O capítulo "A Embrapa e os projetos de cooperação técnica internacional" discorrerá sobre o conceito e a evolução da cooperação internacional para o desenvolvimento, utilizando como referencial teórico uma vasta bibliografia de cooperação internacional e documentos internos da Embrapa. Subdivide-se em: "A Trajetória do Brasil na Cooperação Internacional", "A Trajetória da Embrapa em Cooperação Internacional" e "O Caso do Projeto ProSavana", objeto da pesquisa. A última seção esclarece o cenário do Projeto frente à realidade de Moçambique, região da África Subsaariana mais favorecida em relação aos projetos de cooperação técnica horizontal, que inclui as ações de cooperação trilateral. Suas subseções destacam as distinções entre "O Programa ProSavana - JBM e o milagre do cerrado" e "O Projeto ProSavana-PI: a participação da Embrapa em um cenário conflituoso". De modo geral, são apresentadas ao leitor as interfaces políticas, econômicas e socioculturais que circundam as ações do objeto principal desse estudo. 
O capítulo "A atuação da Embrapa no Projeto ProSavana: análises dos discursos" traz, na seção "Discurso Institucional", informações extraídas, em sua maioria, de pesquisa documental. A seção "Discurso dos cooperantes e especialistas" apresenta as experiências relatadas em entrevistas com os cooperantes do Projeto e especialistas acadêmicos. A seção "Análises dos Discursos" destaca os principais desafios enfrentados pelos cooperantes, bem como as oportunidades percebidas. Espera-se, a partir da análise bibliográfica, documental e das memórias dos cooperantes, contribuir para investigações futuras sobre o tema, bem como para análises das dinâmicas e atuação dos diversos atores envolvidos nesses processos.

No capítulo "Considerações Finais" serão indicadas as tensões, as contradições e as principais questões que atravessaram a implementação do ProSavana. 


\section{REFERENCIAIS EMPÍRICOS E TEÓRICOS}

No contexto da cooperação internacional, o enquadramento da pesquisa recai nas relações entre Brasil e África, a agricultura brasileira e os projetos estruturantes da Embrapa.

Também é preciso embasar-se no referencial teórico sobre a diversidade cultural. Como decorrência, aproxima-se do campo da Antropologia que possui acúmulo de conhecimento sobre a temática. Por ser uma disciplina de comutação e mediação, estabelece uma conexão entre universos de significação, com um mínimo de aparatos institucionais e de instrumentos, dependendo essencialmente de comportamentos pessoais (DA MATA, 1978). Por outro lado, busca-se não somente na Antropologia, mas em outras áreas como a Sociologia, História, Pedagogia, Administração de Empresas, entre outras, um olhar transdisciplinar.

\subsection{Definição do problema de estudo}

Mudanças culturais de grande impacto podem induzir transformações na aparência, forma, natureza ou caráter de determinados elementos típicos das culturas envolvidas ou alterar as relações previamente estabelecidas entre essas. Relacionar-se com outras culturas implica disposição para lidar com outros padrões de pensamento, comportamento e ação: quanto maior for essa interação, em termos de espaço e tempo, maior será o potencial de mudança individual ou coletiva. Entretanto, incorporar passivamente elementos de outras culturas que desconsiderem ou desrespeitem determinados valores individuais e coletivos pode gerar prejuízos significativos. Por isso, para conseguir enfrentar e gerenciar da melhor maneira uma interação cultural, é preciso analisá-la, entendê-la e, de preferência, saber antecipá-la.

No âmbito dos negócios, profissionais e empresas que conseguem prever, planejar e antecipar tais interações obtêm uma vantagem competitiva que permite atingir metas importantes ou adquirir conhecimentos que favoreçam comportamentos mais adequados e propícios diante de um novo contexto. No âmbito específico da cooperação internacional, tema central desta pesquisa, estudar e levar em consideração as características culturais dos países beneficiários, antes 
de se estabelecer uma relação concreta de trabalho, teoricamente, diminui a probabilidade de geração de conflitos e minimiza insucessos.

Nessa perspectiva tornou-se importante levantar dados que permitissem:

1- Avaliar se um dos principais projetos de cooperação internacional desenvolvidos pela Embrapa, no caso o ProSavana, tem previsto e integrado considerações e dinâmicas socioculturais ao atender as demandas essenciais de Moçambique com os quais a instituição interage.

2- Observar como os interlocutores percebem a ideia de cultura e o lugar que ela ocupa na execução dos projetos por eles desenvolvidos;

3- Analisar, ainda que de forma incipiente, como as organizações envolvidas (ABC, Embrapa e JICA) na cooperação técnica oficial entre Brasil e Moçambique percebem o intercâmbio bidirecional de ideias, conhecimentos e experiências relevantes;

4- $\quad$ Avaliar se existe variação na percepção dos cooperantes entrevistados, no que diz respeito ao contexto cultural em que eles se inserem, inclusive em relação ao tamanho e alcance da presença brasileira.

O argumento central dessa dissertação é que o projeto ProSavana, objeto do presente estudo de caso, não considerou as dimensões culturais envolvidas na sua implementação. Pressupõe-se que levar em consideração as diferenças culturais das populações moçambicanas, na fase de formulação de projetos de cooperação técnica internacional (i.e. antes de se estabelecer uma relação concreta de trabalho) possa diminuir a probabilidade de geração de conflitos e minimizar insucessos causados pela execução de planos resultantes apenas de normas e princípios préestabelecidos com base nas suposições e expectativas das entidades provedoras de cooperação.

Várias questões povoam esse cenário de incertezas e norteiam as delimitações para o estudo e o desdobramento do problema de pesquisa (SAMPIERE; COLLADO; LUCIO, 2006), que se concentra na cooperação técnica entre países em desenvolvimento. Desta forma, visam responder à questão central que orienta o projeto: o projeto de cooperação técnica internacional ProSavana previu e integrou considerações e dinâmicas socioculturais ao atender as demandas essenciais de Moçambique? 
A produção de informações para os fins analíticos aqui propostos se deu mediante aos seguintes procedimentos:

1. Identificação das organizações e grupos envolvidos na cooperação técnica oficial entre o Brasil e Moçambique;

2. Mapeamento das percepções dos cooperantes na cooperação técnica oficial entre Brasil e Moçambique sobre possíveis tensões culturais no processo de implementação do projeto.

3. Análise dos relatos dos cooperantes brasileiros envolvidos na implementação do ProSavana a respeito da execução do Projeto (pontos fortes e principais dificuldades no projeto ProSavana).

Espera-se que o estudo do projeto ProSavana, sob o olhar não somente da Embrapa, mas dos principais atores envolvidos, promova reflexões conceituais do universo empírico importantes e contribua para promover melhores práticas estratégicas de atuação na CTPD praticada pelo Brasil, principalmente no âmbito da agricultura.

É fundamental ampliar o debate de política pública, considerando vários atores e incluindo, mesmo que indiretamente, como no caso dessa pesquisa, as comunidades rurais africanas, por meio de critérios que indiquem pontos de análise para o desenvolvimento sustentável rumo ao diálogo sul-sul verdadeiramente instituído. Do ponto de vista aplicável das análises realizadas, dentro do contexto da Embrapa, sabendo por meio das entrevistas, por exemplo, que o modo de transferência de tecnologia é considerado autoritário pelos demandantes, diante dá relação de poder estabelecida, será mais fácil identificar meios mais horizontais de se promover novas parcerias e aprimorar aquelas já estabelecidas.

Além das justificativas e objetivos apresentados, a definição do tema e as prioridades de estudo estão embasadas em um percurso profissional da autora. Graduada em Administração de Empresas, na Universidade de Brasília (UnB) e com especialização (MBA) em "Elaboração, Análise e Avaliação de Projetos", na Fundação Getúlio Vargas (FGV), também em Brasília, hoje, atua na sede da Embrapa. Seu trabalho principal no Departamento de Transferência de Tecnologia (DTT) envolve a elaboração e execução de projetos de Cooperação Sul-Sul, principalmente no eixo Brasil-África para promoção do desenvolvimento rural e erradicação da pobreza. 


\subsection{Procedimentos técnicos}

A escolha pela abordagem da Pesquisa Qualitativa tem como objetivo ir além da superficialidade e analisar os fenômenos sociais com base no cotidiano das pessoas e em uma aproximação crítica das categorias e formas de configuração dessa experiência diária (RICHARDSON et al., 1999).

A Pesquisa Qualitativa é uma tentativa de compreensão detalhada dos significados e características situacionais apresentadas pelos entrevistados (RICHARDSON et al., 1999). É um campo de investigação que atravessa disciplinas, campos e temas (DENZIN; LINCOLN, 2006). O objetivo fundamental dessa abordagem reside no aprofundamento da compreensão de um fenômeno social por meio de entrevistas e análises qualitativas da consciência articulada dos atores envolvidos no processo (RICHARDSON et al., 1999). Consiste em um conjunto de práticas materiais e interpretativas, sejam elas as notas de campo, as entrevistas, as conversas, as fotografias, as gravações e os lembretes. Tais práticas transformam o mundo em uma série de representações. Nesse nível, a pesquisa qualitativa envolve uma abordagem naturalística, interpretativa, para o mundo, o que significa que seus pesquisadores estudam as coisas em seus cenários naturais, tentando entender ou interpretar os fenômenos em termos dos significados que as pessoas conferem a eles. Uma perspectiva positivista neutra ou objetiva não é suficiente. Outros elementos como a classe, a raça, o gênero e a etnia interferem na pesquisa, tornando-a um processo multicultural (DENZIN; LINCOLN, 2006).

Seguindo o pensamento do antropólogo polaco Bronislaw Malinowski, estar treinado e atualizado teoricamente não significa estar carregado de "ideias preconcebidas" e determinado, apenas, a comprovar algumas hipóteses, mas ser capaz de alterar e até abandonar as perspectivas. Observar de forma ampla uma descrição completa dos fenômenos, indo além das caricaturas, para a construção de um todo coerente (MALINOWSKI, 1997).

São várias as opções de estratégias de investigação, paradigmas ou métodos de análise (DENZIN; LINCOLN, 2006). O método do estudo de caso segue a abordagem qualitativa. É uma ferramenta comumente utilizada para se entender o contexto decisório (YIN, 2001). Segundo Yin,

O estudo de caso permite uma investigação para se preservar as características holísticas e significativas dos eventos da vida real - tais

como ciclos de vida individuais, processos organizacionais $\mathrm{e}$ 
administrativos, mudanças ocorridas em regiões urbanas, relações internacionais e a maturação de alguns setores (YIN, 2001, p. 21).

O método pressupõe, como no caso do ProSavana, a existência de um argumento previamente analisado, que será testado no decorrer da investigação e admite a construção de novos argumentos a partir dos achados da pesquisa (YIN, 2001).

Embora pareça contraditório, a escolha parte da abordagem exploratória, após observação não participante e por observação participante. Por meio da observação não participante o pesquisador permanece atento, mas neutro, ou seja, não interage diretamente com o objeto do estudo (RICHARDSON et al., 1999). No caso do projeto analisado, destaca-se que o ProSavana-PI está sob a liderança de técnicos de um outro departamento da Embrapa do qual a autora não faz parte, isto é a Secretaria de Relações Exteriores - SRI. A pesquisadora recebeu autorização para assistir às reuniões do Projeto como ouvinte, mas não foi parte das discussões internas. Entretanto, tendo em vista que a autora trabalha na Embrapa, ela aplicou a observação participante. Sua análise evoluiu à medida que compartilhava as mesmas vivências dos sujeitos pesquisados, ao atuar com projetos de Cooperação Internacional, sendo parte da mesma "tribo" institucional. Dessa forma, sua história e aquela de seus colegas se complementam, tendo em vista que são todos integrantes dos mesmos processos políticos e da mesma cultura organizacional. Juntos compartilham dos mesmos temores, traumas, fantasias e esperanças quando são alterados os "caciques" e as rotinas de suas vidas selvagens. O processo é complexo, porque conforme Malinowski,

\begin{abstract}
Aprendemos muito sobre o enquadramento da sociedade em causa, mas não conseguimos aperceber-nos ou imaginar dentro dele as realidades da vida humana, o fluxo rotineiro dos acontecimentos diários, as ondas ocasionais de agitação provocadas por uma festa ou cerimônia ou qualquer acontecimento particular. No momento de organizar as normas e preceitos dos costumes locais, resumindo-os a uma fórmula alcançada através da recolha de dados e declarações dos nativos, acabamos por concluir que esta precisão é estranha à vida real que nunca adere rigidamente a qualquer norma. Torna-se então necessário complementar este ponto de vista através da observação da maneira como determinado costume é posto em prática, do comportamento dos nativos mediante as regras formuladas de modo tão preciso pelo Etnógrafo e das muitas exceções que ocorrem quase sempre nos fenômenos sociológicos (MALINOWSKI, 1997, p. 14).
\end{abstract}

Dessa forma, a análise pela observação participante possibilita uma compreensão e até o compartilhar da mesma sensibilidade diante dos movimentos político-institucionais ao longo do estudo. 
Embora o estímulo da própria pesquisa pudesse ter um cunho individual acadêmico e não institucional, ele ganhou uma nova dimensão, a partir do desejo de outros técnicos de que o estudo produzisse resultados relevantes para seus trabalhos.

A observação é imprescindível em qualquer processo de pesquisa científica. É a base de qualquer investigação no campo social. Embora possa ser apresentada como um conjunto de curiosidades interessantes, em termos científicos exige o exame minucioso sobre um fenômeno e deve ser submetida a verificações e controles de validade e precisão (RICHARDSON; et al., 1999). No entanto, a tarefa de pesquisa exige tanto o ato de observar quanto o de comunicar os resultados das análises (DENZIN; LINCOLN, 2006).

A pesquisa qualitativa disponibiliza várias técnicas de coleta de dados, incluindo a observação participante e não participante, grupos de discussão e entrevistas; porém, cada uma delas pode apresentar problemas de validade. Um meio para tratar a relação entre observação e crítica social está na reconceituação de validez em termos de prática reflexiva, ou seja, implicando uma compreensão consciente do pesquisador ao longo do processo de pesquisa, desde 0 planejamento do projeto até as conclusões refletidas no relatório. A preocupação com a validade das informações recai tanto para as análises coletadas (isto é, se os dados expressam, autenticamente, a visão do entrevistado) como para a própria análise do pesquisador (DENZIN; LINCOLN, 2006).

Ainda que as técnicas possam ser apresentadas, sua aceitação dependerá da confiança na integridade ética do pesquisador (RICHARDSON; et al., 1999).

O campo de pesquisa em cultura é caracterizado por grande diversidade e múltiplos conceitos. Se, por um lado, oferece riqueza e pluralidade, por outro apresenta dispersão. A estratégia de pesquisa, ao longo da pesquisa qualitativa, envolve o emprego de métodos e de algumas técnicas de pesquisa. As técnicas são procedimentos operacionais que servem de mediação prática para a realização das pesquisas, que precisam ser coerentes com os métodos e paradigmas epistemológicos adotados (SEVERINO, 2007).

O presente estudo tem como principais referenciais metodológicos a pesquisa exploratória, a pesquisa documental, a pesquisa bibliográfica e a pesquisa etnográfica multissituada, que serão descritas brevemente a seguir. 


\subsubsection{Pesquisa exploratória ou estudo preliminar}

A pesquisa exploratória busca levantar informações sobre um determinado objeto (SEVERINO, 2007). É utilizada quando o pesquisador pretende familiarizar-se com o fenômeno que está sendo investigado, de modo que as fases subsequentes possam ser concebidas com mais maturidade e precisão. Consiste em descobrir o campo de pesquisa, os atores envolvidos e suas expectativas e, a partir desse contato prévio, realizar um diagnóstico da situação e da relevância da pesquisa. A escolha se deu por leituras sobre CTPD, participação em grupos de estudo e entrevistas com líderes de projetos de Cooperação Internacional da Embrapa.

\subsubsection{Pesquisa documental e bibliográfica}

Para conseguir abordar vários aspectos com razoável grau de embasamento, houve a necessidade de se fazer uma opção metodológica, a começar por uma análise documental e uma revisita aos documentos dos projetos ProSavana. A pesquisa documental tem como fonte documentos que ainda não tiveram tratamento analítico (SEVERINO, 2007). Para fins dessa pesquisa foram utilizados relatórios dos projetos, planos técnicos, relatos de viagem, folhetins internos, vídeos e outros documentos da Embrapa.

A pesquisa bibliográfica utiliza-se de dados já trabalhados por outros pesquisadores (SEVERINO, 2007). É realizada a partir de registros disponíveis, decorrentes de pesquisas anteriores, em documentos impressos (artigos, livros, jornais, revistas, teses, etc.). Nesse caso, a autora utiliza-se de referências nacionais e internacionais sobre as temáticas específicas. Assim sendo, a pesquisa bibliográfica foi composta, principalmente, a partir do estudo dos autores que abordam o tema Cooperação Internacional: o cientista político e sociólogo espanhol José Ángel Sotillo; o cientista político estadunidense Robert Keohane; os antropólogos brasileiros Daniel Simião e Kelly Cristiane da Silva; a internacionalista brasileira lara Costa Leite; cientistas sociais como o inglês Alex Shankland e a portuguesa Lídia Cabral; e vários autores africanos, como o beninense Paulin Hountondji, os congoleses Mbuyi Kabunda Badi e V. Y. Mundimbe, entre tantos outros. No que tange à fundamentação teórica sobre cultura, o estudo reflete as formulações teóricas do italiano Antonio Gramsci, do indiano Homi K. Bhabba, do 
argentino Néstor Garcia Canclini e do jamaicano Stuart Hall. A metodologia de trabalho foi construída a partir da visão antropológica do historiador e antropólogo brasileiro Roberto Da Matta, do antropólogo polaco Bronislaw Malinowski e do sociólogo francês Maurice Halbwachs. Vários outros autores foram pesquisados e são citados ao longo do estudo.

\subsubsection{Pesquisa Etnográfica Multissituada}

A pesquisa etnográfica está respaldada por um desenho da Antropologia Social que valoriza a coleta de dados etnográficos e as tarefas de transformar "o exótico no familiar" e "o familiar no exótico" (DA MATA, 1978). Etnografia refere-se, literalmente, a uma descrição de um povo e da sua base cultural (ANGROSINO, 2008). "É a arte e a ciência de descrever um grupo humano - suas instituições, seus comportamentos interpessoais, suas produções materiais e suas crenças" (ANGROSINO, 2008, p. 30). Os etnógrafos inspiram-se no conhecimento dos resultados mais recentes da pesquisa científica, nos seus princípios e objetivos (MALINOWSKI, 1997). Orientam seus estudos por imagens do mundo e pelas vidas cotidianas rotineiras das pessoas que eles estudam (ANGROSINO, 2008; DENZIN, et al., 2006). Mergulham no microssocial com uma lente de aumento (SEVERINO, 2007). Quando o etnólogo familiariza-se com uma cultura diferente da sua, ele adquire competência nesta cultura (DA MATA, 1978).

Diante da impossibilidade da pesquisadora em realizar uma pesquisa de campo com os próprios camponeses, o contexto e as experiências dos povos foram apresentados por meio das narrativas e memórias dos cooperantes brasileiros que estiveram à frente dos trabalhos de execução dos projetos. Buscou-se entender como questões culturais atravessam e dão sentido às narrativas de seus interlocutores. Os casos contados começaram a incorporar o imaginário da pesquisadora. Diferentes narradores selecionam fatos e histórias diversas, dão significados e reinterpretam os fatos a seu modo e a cada vez que recuperam suas memórias, refazem as narrativas com um novo colorido, comparando aquele contexto ao de "agora".

Paralelamente, o exercício de afastamento da função de analista da Embrapa para analisar, com olhos acadêmicos, o formato e estilo de trabalho da Empresa ao tratar a CTPD, principalmente nos projetos ProSavana, gradualmente se impôs na 
execução do trabalho de pesquisa. Em vários momentos foi preciso analisar a Embrapa, como se ela mesma fosse a tribo exótica com a qual se buscou tanto a familiarização como o estranhamento, tanto a aproximação quanto o afastamento.

Letícia Cesarino salienta em suas análises que "as relações entre o etnógrafo e seus informantes são relações sociais como quaisquer outras”, mas apresenta um desafio quando afirma que "decerto é mais fácil objetificar um indígena melanésio do que um cooperante brasileiro" (CESARINO, 2014, p. 23) No caso dessa pesquisa, a distância relacional entre a pesquisadora e os seus informantes é curta, principalmente quando se trata dos informantes "embrapianos". Não há rompimento entre o campo da pesquisa acadêmica e o escritório. Dessa forma, fica mais difícil sustentar o privilégio epistemológico de definir unilateralmente a priorização e a relevância das escalas e contextos para enquadrar as práticas dos informantes (CESARINO, 2014). Ela acrescenta que:

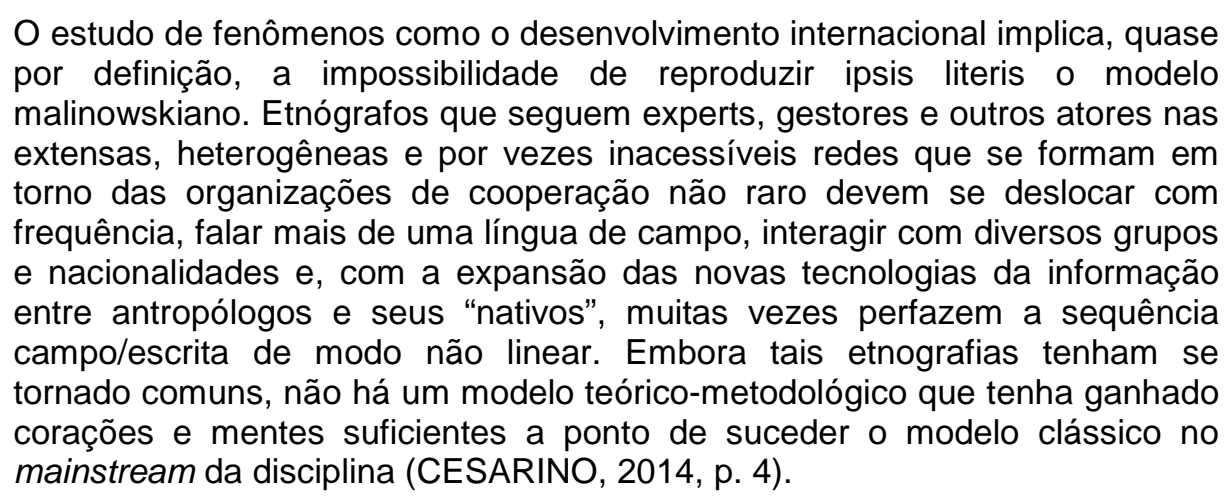

A partir dessa afirmação, ela conclui que um dos modos mais conhecidos de colocar essa problemática foi a discussão de George Marcus ${ }^{1}$ (1995) sobre a etnografia multissituada, a qual "implica em seguir etnograficamente a 'circulação de atores', objetos e discursos por múltiplos pontos do globo" (CESARINO, 2014, p. 4).

\subsubsection{Entrevistas semiestruturadas}

A entrevista é uma técnica de coleta de informações muito utilizada nas pesquisas da área das Ciências Humanas (SEVERINO, 2007). É utilizada a fim de promover maior interação entre pesquisador e pesquisado, afinal, normalmente, as pessoas estão mais receptivas a responder as perguntas feitas por uma pessoa real

\footnotetext{
${ }^{1}$ George E. Marcus - professor americano, autor do estudo Ethnography in/of the world system: the emergence of multisited ethnography. Annual Review of Anthropology.
} 
do que responder ao questionário enviado pelo correio ou Internet (COZBY, 2003). A própria abordagem da pesquisa é coerente com a proposta de aproximar pessoas, de desenvolver diálogos.

Nas entrevistas estruturadas, as questões são direcionadas e previamente estabelecidas, enquanto que nas entrevistas não-diretivas, colhem-se as informações dos entrevistados a partir do seu discurso livre (SEVERINO, 2007). As entrevistas semiestruturadas combinam perguntas abertas e fechadas e, embora 0 pesquisador deva seguir um conjunto de questões previamente definidas, ele o faz em um contexto semelhante ao de uma conversa informal. Dessa forma, o informante tem a possibilidade de discorrer sobre o tema proposto (BONI; QUARESMA, 2005). Além disso, sendo os sujeitos entrevistados individualmente, com questões abertas, fica assegurada a liberdade das respostas. A finalidade é obter registros de experiências e opiniões relevantes e conhecer suas percepções, vivências e observações coletadas a partir da opinião das populações impactadas, a partir dos construtos escolhidos: atitude, norma subjetiva, hábito e intenção de comportamento, valores, crenças, sensibilidade cultural das lideranças, predisposição para integração ou conflito, percepção de solidariedade e horizontalidade, o grau de envolvimento e de diferenças culturais como variáveis moderadoras.

Os entrevistados são os cooperantes, profissionais envolvidos direta ou indiretamente nos projetos, por serem capazes de dar as respostas específicas do ambiente dos projetos da Embrapa. Com o objetivo de manter a discrição quanto aos nomes dos profissionais que responderam às entrevistas, eles são identificados como informantes, um termo comum em antropologia. Desse modo, são denominados e categorizados como informantes internos (Embrapa) e informantes externos, sendo que essa última categoria inclui funcionários oficiais do Brasil e de países beneficiários, tais como: Agência Brasileira de Cooperação $(A B C)$, Agência de Cooperação Internacional do Japão (JICA) e instituições beneficiárias da cooperação diretamente nos países indicados. Nota-se que a categoria de informantes externos inclui pesquisadores que se dedicaram ao estudo aprofundado do Projeto ProSavana. Esse grupo inclui acadêmicos que pesquisam desenvolvimento internacional no Brasil e exterior, sendo eles das instituições: Universidade de Brasília (UnB), Institute of Development Studies (IDS), e Pontifícia Universidade Católica do Rio de Janeiro (PUC-Rio). Em tempos de maior interação 
de diferentes públicos junto às mídias sociais, visitas e acompanhamento de informações sobre o projeto no Google, Twitter, Facebook e grupos de cooperação internacional no Linkedin, também foram utilizados como recursos tecnológicos da pesquisa.

Embora o tamanho da amostra não seja elevado, o que poderia enfraquecer o intervalo de confiança, o percentual de entrevistados envolvidos diretamente com a temática de pesquisa é alto. Por exemplo, mesmo que na Embrapa tenha 9.825 empregados contratados, o número de pessoas que trabalham com projetos de cooperação técnica na África Subsaariana e que suas opiniões têm maior relevância para a pesquisa, é por volta de quinze. $\mathrm{Na} A B C$, o número não ultrapassa quatro entrevistados e nas instituições parceiras dos projetos, inclui até dois responsáveis. Embora o quantitativo possa parecer baixo, a busca na amostra é por atingir em, no mínimo, $80 \%$ dos profissionais envolvidos nos projetos, por meio de entrevistas individuais e coletivas.

\subsubsection{Entrevistas coletivas}

As técnicas de coleta de dados organizadas no contexto grupal são comuns em métodos qualitativos de pesquisa. Consistem em estratégias únicas ou complementares de outros instrumentos de pesquisa como observação e entrevista individual (MINAYO, 2007). Os indivíduos reconstituem toda uma sequência de atos e palavras ditas dentro de determinadas circunstâncias e, muitas vezes, evocam fatos que uma pessoa, individualmente, não se recordaria. Em grupo, as lembranças se complementam, favorecendo o registro e o relato completo da história. Por outro lado, muitas vezes, as imagens reconstruídas pelo grupo são menos exatas do que as imagens reconstruídas individualmente. Pode ser que essas imagens não reproduzam o passado da maneira mais correta e que a lembrança que estava primeiramente na memória seja sua expressão exata: "a algumas lembranças reais se junta uma compacta massa de lembranças fictícias" (HALBWACHS, 1950, p. 28).

O oposto também pode ocorrer: os depoimentos dos outros podem corrigir e reorientar a lembrança do indivíduo, tornando-os aptos a descrever com certa exatidão o conjunto dos fatos ocorridos (HALBWACHS, 1950).

Ao longo do trabalho, foi possível realizar pesquisas com pequenos grupos da extinta Embrapa Estudos e Capacitação - Cecat e participar, como observadora, 
nas reuniões da Secretaria de Relações Internacionais - SRI da Embrapa sobre o Projeto ProSavana, fossem internas ou externas, com parceiros da Agência Brasileira de Cooperação - ABC. As conversas informais nos coffee-breaks eram também importantes para alimentar o "Diário de Campo" da pesquisadora.

\subsubsection{A interação entre os procedimentos técnicos}

Ainda que as etapas da estratégia de pesquisa tenham sido apresentadas seguindo alguma ordem cronológica, as fases se misturam em vários momentos e seguem um constante ir e vir. Além disso, dificilmente o processo de coleta de dados pode ser descrito em sua totalidade. Na prática, as "histórias de campo" fazem parte de um processo social em andamento que em sua experiência cotidiana desafia a recapitulação. O objetivo de elaborar uma descrição completa do método de coleta de dados seria uma atitude que deslocaria a estrutura da referência etnológica, substituindo, na realidade, o meio pelo fim (DENZIN; LINCOLN, 2006, p. 50). O sociólogo Pedro Demo argumenta que:

Seria um erro superestimar a metodologia, no sentido de cuidar mais dela do que de fazer ciência. O mais importante é chegarmos onde nos propomos chegar, ou seja, a fazer ciência. A pergunta pelos meios de como chegar lá é essencial também, mas é especificamente instrumental. Somente o metodólogo profissional faz dela sua razão de ser, principalmente o filósofo da teoria do conhecimento. Mas, para o cientista em geral, é apenas disciplina auxiliar (DEMO, 1985, p. 19).

Embora não se queira transformar a metodologia na razão de ser da pesquisa, foi dado um tratamento científico ao processo. Segundo Malinowski,

O tratamento científico difere do mero senso comum, em primeiro lugar, porque um investigador ampliará muito mais a perfeição e minúcia do inquérito, de forma escrupulosamente metódica e sistemática; em segundo lugar, porque a sua mente, treinada cientificamente, conduzirá a pesquisa através de pistas realmente pertinentes, a metas de importância efectiva. De facto, o objetivo do treino científico é dotar o investigador empírico de um mapa mental pelo qual se possa orientar e definir o seu caminho (MALINOWSKI, 1997, p. 26).

Assim sendo, a pesquisa foi norteada pela execução sistemática e constante de procedimentos técnicos, tais como o levantamento apurado de documentos da Embrapa, a análise da literatura e dos vários tipos de referências bibliográficas (acadêmicas e não acadêmicas) e a realização de entrevistas com os cooperantes, visando compreender as diferentes percepções sobre o objeto do estudo. 


\section{OS REGISTROS HISTÓRICOS E O PASSADO DA EMBRAPA COM OLHOS DO PRESENTE}

Ainda que o foco desta pesquisa seja o estudo da cooperação técnica internacional praticada pela Embrapa, principalmente levando em consideração o Projeto ProSavana, fez-se premente rememorar marcos históricos. Aliás, como o tema do estudo versará sobre cultura entre povos, tornou-se importante considerar a trajetória histórica institucional da Embrapa, o contexto de suas origens e a construção de sua própria cultura organizacional, a fim de se compreender o presente e quiçá, pensar em estratégias para o futuro².

A Embrapa é referência mundial no seu campo de atuação. Desde sua criação, em 26 de abril de 1973, destacou-se na modernização da agricultura, com proposta técnica e metodológica de geração e difusão de tecnologia. À época, essa proposta esteve assentada na montagem de pacotes tecnológicos, implicando a combinação de inovações técnicas e insumos de origem industrial, como uma linha de produção que não poderia ser rompida sob o risco de invalidar os resultados da exploração agrícola (CABRAL, 2005; EMBRAPA INFORMAÇÃO TECNOLÓGICA, 2006). Segundo Ronaldo Conde Aguiar, "o pacote tecnológico consiste num conjunto de práticas e procedimentos técnicos que se articulam entre si e que são utilizados indivisivelmente numa lavoura, segundo padrões estabelecidos pela pesquisa" (AGUIAR, 1986, p. 17).

Segundo a Embrapa Informação Tecnológica:

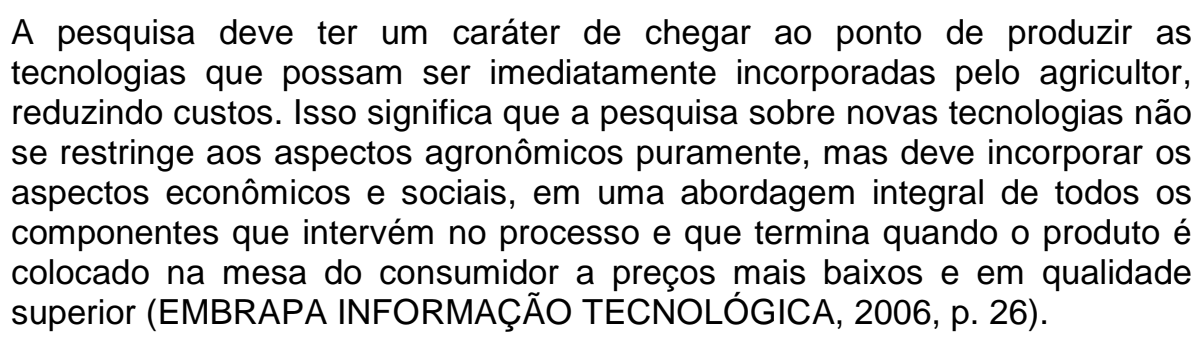

Nesse momento, o cenário se traduzia em uma crescente importância da tecnologia, como instrumento fundamental para ampliação da produtividade e retornos econômicos rápidos. Dentro dessa lógica de dinamismo e rentabilidade, é

\footnotetext{
${ }^{2}$ Foram utilizadas, principalmente, duas publicações que retratam a memória da Embrapa, ambas publicadas em 2005, a saber: i). a edição especial do documento "Sugestões para formulação de um Sistema Nacional de Pesquisa Agropecuária", também chamado de "Livro Preto", foi fundamental no apoio às decisões governamentais no processo de reformulação do Sistema de Pesquisa Agropecuário do País, a partir de 1972, e produto principal da reforma institucional, que resultou na criação da Embrapa; ii) o "Sol da Manhã", de autoria do primeiro presidente da Embrapa, J. Irineu Cabral.
} 
lançada a ideia de "packages" ou pacotes tecnológicos. No Livro Preto é explicitado que:

Tendo em vista que o processo não pode ser dividido em tecnologias estanques, devido à grande interação existente entre os diversos fatores de produção, está implícito, dentro deste princípio, a ideia de que a pesquisa deve ser planejada, tendo em conta o produto com a visão do 'package' (EMBRAPA INFORMAÇÃO TECNOLÓGICA, 2006, p. 26).

Irineu Cabral argumenta que:

A ideia foi no sentido de formular 'sistemas de produção' utilizando-se conhecimentos disponíveis e divulgá-los, da melhor maneira possível, entre grupos de agricultores. Esses 'sistemas de produção' passaram a ser conhecidos como os 'pacotes tecnológicos' (CABRAL, 2005, p. 113).

Foram lançados entre 1974 e 1975 mais de cem pacotes correspondentes e vários sistemas de produção. [...] Os 'pacotes tecnológicos' alcançaram enorme popularidade, particularmente, entre os agricultores e criadores de animais (CABRAL, 2005, p. 117).

Em seguida, foram sendo ampliados e desenvolvidos pacotes para cultivares de plantas e raças de animais mais adaptadas ao meio ambiente, bem como sistemas de cultivo inovadores, calendários e zoneamento agroclimático, métodos de conservação e uso sustentável de recursos genéticos e naturais; e integração de biotecnologia e automação na agricultura.

A estratégia utilizada na agricultura seguia a lógica do capital internacional e sustentava-se em um modelo econômico caracterizado pela concentração de renda e por uma conjuntura repressiva, com apoio internacional. Nesse momento, em que o Governo apostava em fortalecer institucionalmente a extensão rural, o papel da Embrapa foi de operacionalizá-la (VALENTE; et.al, 2015, no prelo).

LISITA argumenta que:

A extensão rural no Brasil nasceu sob o comando do capital, com forte influência norte-americana e visava superar o atraso na agricultura. Para tanto, havia a necessidade de "educar" o povo rural, para que ele passasse a adquirir equipamentos e insumos industrializados necessários à modernização de sua atividade agropecuária, com isso ele passaria do atraso para a "modernidade". O modelo serviria para que o homem rural entrasse na dinâmica da sociedade de mercado, produzindo mais, com melhor qualidade e maior rendimento (s.d.).

Promoveu-se, desse modo, uma transformação tecnológica e cultural da agricultura nas décadas seguintes. Essa seria a marca da agricultura brasileira. LISITA (s.d.) conceitua tal modelo e o nomeia como modelo tecnicista: 
Um modelo 'tecnicista', isto é, com estratégias de desenvolvimento e intervenção que levam em conta apenas os aspectos técnicos da produção, sem observar as questões culturais, sociais ou ambientais. Com raízes 'difusionistas', pois visa apenas divulgar, impor ou estender um conceito, sem levar em conta as experiências e os objetivos das pessoas atendidas.

O modelo tecnicista, herdado dos Estados Unidos entre as décadas de 1960 e 1970, esteve em franca expansão no Brasil, e a Embrapa o incorporou em suas atividades, considerando-o como o mais apropriado. Entretanto, em vários debates acadêmicos e institucionais, foi cada vez mais contestada a perpetuação de conclusões científicas supostamente incontestáveis e, por contraste, foi promovida a prática da reflexão crítica.

Paulo Freire, educador brasileiro de renome internacional, publicou um ensaio em 1969, no Chile, sob o título “Extensão ou Comunicação?”. Ele, inclusive, iniciou seu texto de forma crítica: "A PRIMEIRA PREOCUPAÇÃO que nos impomos ao começar este estudo é submeter a palavra extensão a uma análise crítica" (FREIRE, 1977, p. 19, grifo do autor). Com relação ao termo extensão, FREIRE indica que "na medida em que, no termo extensão, está implícita a ação de levar, de transferir, de entregar, de depositar algo em alguém, ressalta, nele, uma conotação indiscutivelmente mecanicista” (FREIRE, 1977, p. 26).

Anos mais tarde, no "Seminário Nacional de Assistência Técnica e Extensão Rural: uma nova extensão para a agricultura familiar", realizado em 1998, um de seus participantes, o Hur Ben Correa da Silva, atualmente contribuindo no Ministério do Desenvolvimento Agrário - MDA, criticou:

Hur Ben Correa da Silva, da FASER, fala de um sistema vertical destinado à difusão dos pacotes tecnológicos, baseado em métodos skinnerianos ${ }^{3}{ }_{-}$ batizados sem hesitação de "lavagem cerebral" - e onde o progresso material é explicado pela capacidade de aderir às novas técnicas e a pobreza vista como atributo dos culturalmente atrasados (ABRAMOVAY, 1998, p. 142).

Marcos Peixoto, consultor legislativo do Senado Federal, em seu estudo sobre a extensão rural no Brasil, afirma que "o termo extensão rural não é auto-explicativo" e que "desde a implantação do modelo cooperativo de extensão americano foram muitas as iniciativas de conceituação da extensão rural” (PEIXOTO, 2008, p. 10). Ele diferencia a extensão rural de assistência técnica. Segundo ele, a "extensão rural é

\footnotetext{
${ }^{3}$ Deriva de Burrhus Frederic Skinner (1904-1990), autor e psicólogo americano que conduziu trabalhos pioneiros em psicologia experimental e foi o propositor do Behaviorismo Radical, abordagem que busca entender o comportamento em função das inter-relações entre a filogenética, o ambiente (cultura) e a história de vida do indivíduo.
} 
um processo educativo de comunicação, de conhecimentos, de qualquer natureza, sejam conhecimentos técnicos ou não". Por outro lado "a assistência técnica não tem, necessariamente, um caráter educativo, pois visa somente resolver problemas específicos, pontuais, sem capacitar o produtor rural" (PEIXOTO, 2008, p. 10).

Quando Freire promoveu uma reflexão sobre o termo extensão, ele clarifica que, embora, "em seu campo associativo, o termo extensão se encontre em relação significativa com transmissão, entrega, doação, messianismo, mecanicismo, invasão cultural, manipulação, etc." (FREIRE, 1977, p. 22), "extensão não é isto; a extensão é educativa" (FREIRE, 1977, p. 22).

Embora começasse, paralelamente a repercutir no Brasil, uma abordagem mais dialógica com a comunidade, o modelo americano encontrou consonância, visto que os técnicos da Embrapa, em busca de aperfeiçoamento profissional, foram, em grande parte, estudar nos Estados Unidos.

Não demorou muito e a própria Embrapa começou a repensar seu modelo. Segundo os "Anais dos Encontros Regionais sobre Difusão de Tecnologia", publicados em 1990:

Os primeiros Encontros Regionais de Difusão de Tecnologia aconteceram em 1978, oportunidade em que foram identificados os problemas na operacionalização do modelo de difusão, avaliados os aspectos de programação de trabalhos e repensadas as estratégias de ação com vistas à melhoria do desempenho das atividades de difusão (EMBRAPA, 1990, p. 9).

No entanto, o repensar do modelo não envolvia uma mudança em sua abordagem, tendo em vista que chegou a se formalizar uma estrutura com uma coordenadoria para ocupar-se das "atividades de venda de tecnologia e serviços produzidos pela Empresa aos setores privado e governamental, do País e do Exterior" (EMBRAPA, 1990, p. 9).

A preocupação com qualidade da pesquisa, envolvimento de múltiplos atores e atendimento ao produtor rural é expressa no "Marco Conceitual da Difusão de Tecnologia e Organização do DDT", ou seja:

O conceito de difusão de tecnologia com que o Departamento de Difusão de Tecnologia trabalha pode ser assim descrito: É um processo que se engloba todas as ações consideradas necessárias e complementares para que haja a maior interação possível entre pesquisadores, extensionistas, produtores e órgãos de política agrícola, em todas as etapas de geração e transferência de tecnologia, visando à sua maior eficiência e eficácia. 


\begin{abstract}
Uma preocupação genuína com a difusão de tecnologia não se centra apenas nos problemas mais imediatamente ligados à condução de uma inovação qualquer ao seu usuário potencial. Prender-se a essa questão é negligenciar o possível caráter problemático da tecnologia em si. Em outras palavras é pressupor que aquilo que é produzido é bom. Nesta linha, acredita-se que se existe algum tipo de problema ele estaria localizado na ação ineficiente do extensionista ou na resistência do produtor rural. No máximo, seriam verificados os efeitos da política econômica no trabalho do extensionista ou na ação do produtor (EMBRAPA, 1990, p. 19).
\end{abstract}

No entanto, a lógica é de um processo unidirecional: geração-difusão-adoção. É verdade que "a Embrapa é uma das instituições de pesquisa mais responsáveis pelas conquistas científicas e tecnológicas da agricultura brasileira" (EMBRAPA, 1990 , p. 20). Também que "o Brasil foi um dos poucos países [...] a passar de importador líquido de alimentos, na década de 1960, para autossuficiente, ou mesmo para exportador de alimentos, a partir da década de 1980" (VIEIRA FILHO, 2014 , p. 398). Porém, "ainda que tecnologia e produtividades sejam importantes, atualmente não mais se sustenta a lógica linear da geração, adoção e difusão e seus modelos de demanda e oferta" (SALLES-FILHO; BIN, 2014, p. 427).

Anos se passaram e, embora haja um interesse crescente pela busca do diálogo, ainda carece, por parte da Embrapa, maior reflexão e iniciativas coerentes. Ao resgatar os documentos com a memória da Embrapa é perceptível que soluções dadas naquele tempo e que poderiam ser condizentes com aquele momento continuam sendo replicadas. Podemos dar soluções antigas para problemas atuais? Nem sempre. "Para alcançar a inclusão social e produtiva da agricultura familiar e das comunidades tradicionais, é necessário um novo tipo de pesquisa que incorpore a subjetividade do ser humano a partir do diálogo entre os sujeitos" (GASTAL, 2013).

Ainda que uma política de transferência de tecnologia tenha sido discutida a partir de iniciativas do Departamento de Transferência de Tecnologia da Embrapa, com debates realizados por meio de videoconferências com todas as unidades da Empresa, ela nunca foi, de fato, publicada e implementada. É percebida, até mesmo pelos próprios empregados da Embrapa, a dificuldade em conceituar os termos e utilizar, de maneira adequada cada um deles em seus discursos. Termos como extensão rural, assistência técnica, transferência de tecnologia e intercâmbio de conhecimento chegam a ser utilizados no mesmo discurso como sinônimos, sendo que alguns são complementares ou até mesmo contraditórios. Essa carência de clareza ocorre, certamente, não por falta de conceitos apropriados ou por falta de obras que esclareçam tais diferenças e similaridades. 
Houve, por parte dos profissionais que atuam na área, uma maior compreensão do conceito de transferência de tecnologia, a partir da criação do DTT e, principalmente, por meio da realização de debates entre os profissionais da área. A partir do momento em que se logrou esse esclarecimento, ampliou-se a compreensão da incoerência entre o que a Empresa pretende realizar, o intercâmbio de conhecimento, e sua denominação formal, a transferência de tecnologia.

Embora haja um interesse crescente pela busca de modelos que valorizem o diálogo, e embora essa preocupação esteja presente nos discursos institucionais, tal prática ainda é incipiente. No âmbito de alguns projetos nacionais e internacionais de cooperação, já foram realizadas reuniões com as comunidades e iniciados diálogos participativos. De qualquer modo, a prática de escuta e estímulo às soluções compartilhadas dentro da própria comunidade beneficiada é um processo que está amadurecendo na Empresa. Foi iniciado e estimulado, mas ainda não é um comportamento padrão. Como seria possível falar então de intercâmbio de conhecimento, nos moldes que Freire apregoa?

[...] Conhecer, na dimensão humana, que aqui nos interessa, qualquer que seja o nível em que se dê, não é o ato através do qual um sujeito, transformado em objeto, recebe, dócil e passivamente, os conteúdos que outro Ihe dá ou impõe. O conhecimento, pelo contrário, exige uma presença curiosa do sujeito em face do mundo. Requer sua ação transformadora sobre a realidade. Demanda uma busca constante. Implica em invenção e em reinvenção. Reclama a reflexão crítica de cada um sobre 0 ato mesmo de conhecer, pelo qual se reconhece conhecendo e, ao reconhecer-se assim, percebe o "como" do seu conhecer e os condicionamentos a que está submetido seu ato (FREIRE, 1977, p. 27).

Freire destaca o termo apropriação em seu texto, afirmando que:

Só aprende verdadeiramente aquele que se apropria do aprendido, transformando-o em apreendido, com o que pode, por isto mesmo, reinventá-lo; aquele que é capaz de aplicar o conteúdo aprendidoapreendido a situações existenciais concretas (FREIRE, 1977, p. 27).

Qual seria, então, o papel da Embrapa como empresa de ciência, tecnologia e inovação para o desenvolvimento da agricultura?

Se, por um lado, Freire (1977) destaca a importância da apropriação e de um diálogo problematizado, Vieira Filho (2014) aponta que não a educação, mas a ausência dela (ou seja, o baixo nível de instrução e os elevados índices de analfabetismo) no país são empecilhos à aprendizagem e inclusão rural.

No que se refere ao nível de instrução, [...] percebe-se que a educação é um ponto-chave no desenvolvimento agropecuário, e que os números são 
bastante desfavoráveis para o Brasil em geral, mas fundamentalmente piores nas regiões Nordeste e Norte. No Brasil, 29,8\% das pessoas que dirigem os estabelecimentos são analfabetas. No Nordeste, esse percentual de analfabetos é de $46,4 \%$. A região com o menor índice de analfabetismo e o Sul, com $7,4 \%$ do total dos dirigentes daquela região. No outro extremo, ao avaliar o percentual de dirigentes com ensino superior, os números são muito baixos, não tendo nenhuma região que se destaque. No CentroOeste, $6,5 \%$ dos dirigentes possuem nível superior, enquanto, no Sul, 3,4\% apenas (VIEIRA FILHO, 2014, p. 413-416).

Segundo ele, "para compreender a forte concentração na produção agrícola brasileira, é preciso avaliar não somente a distribuição tecnológica, como também a capacidade de absorção de conhecimentos" (VIEIRA FILHO, 2014, p. 416).

No que se refere à inclusão rural, Eliseu Alves ${ }^{4}$ et. al salienta a importância da tecnologia, mas ataca o modelo de difusão de tecnologia brasileiro que concentra a produção e não inclui uma grande margem de agricultores.

A tecnologia impulsionou o agronegócio, sendo principal responsável pelo seu sucesso. [...] Tecnologia explica o crescimento da produção. Como quinhentos mil estabelecimentos produziram $87 \%$ da produção de 2006 e 3,9 milhões deles tiveram insignificante participação, segue-se que pequena parcela dos agricultores foi capaz de se beneficiar da modernização da agricultura e a grande maioria ficou à margem. Confirma-se, assim, que é a tecnologia que explica a concentração da produção.

A solução agrícola para o problema de pobreza da agricultura requer que tecnologia seja também o carro-chefe da modernização da agricultura pobre e da agricultura familiar. Aí está o problema de difusão de tecnologia brasileiro. No caso dos 500 mil produtores, a difusão de tecnologia foi um sucesso. Esse grupo tem condições de transformar conhecimentos em sistemas de produção lucrativos, financiar a compra de insumos e de bens de capital, e de vender bem a produção no mercado interno e externo. É, portanto, imperativo dar condições semelhantes àqueles que estão à margem do progresso. Aí está o grande desafio da nossa política agrícola, do tamanho de 3,9 milhões de estabelecimentos! (ALVES; et al., 2013, p. 44).

A análise dos elementos aponta para uma pluralidade nas visões, opiniões até mesmo dentro da própria Embrapa. Algo bastante claro, citado por Sergio Salles Filho e Adriana Bin (2014),

Muito mudou nesse mundo agrário brasileiro e as instituições típicas da pesquisa científica e tecnológica estão um tanto deslocadas, tentando reencontrar-se nesse cenário. Esse não é apenas um fenômeno brasileiro ou de países menos desenvolvidos: é um fenômeno geral. Entretanto, alguns países estão mudando seus modelos mais rápido que outros (SALLES-FILHO; BIN, 2014, p. 425-426).

\footnotetext{
${ }^{4}$ Eliseu Alves ${ }^{4}$, atualmente assessor da Presidência da Embrapa, já foi Diretor da Embrapa (19731979), Presidente da Embrapa (1979-1985) e Presidente da Codevasf (1985-1990).
} 
A busca por um diálogo mais frequente e aberto para enfrentar os desafios e promover interpretações consistentes sobre as realidades agrárias ainda é ideológico; sua prática é incipiente e experimental. O modelo desenvolvido no passado, em um contexto bem diferente, ainda que replicado não pode assegurar um sucesso semelhante e duradouro. Paulo Correa e Cristiane Schmidt são bastante específicos e indicam o que pode ser replicável e o que deve ser aprimorado:

Os arranjos institucionais e políticas operacionais independentes da Embrapa, investimento público sustentado em pesquisa orientada para a missão, investimento em capital humano, e integração no fluxo internacional de conhecimento - são certamente replicáveis através de uma variedade de ambientes políticos. Configurar uma organização de pesquisa pública com uma estrutura semelhante irá exigir apoio político e financeiro contínuo, bem como foco em resultados tangíveis, práticos. O aspecto de personalização da operação da Embrapa, com pesquisadores que focam em tecnologias voltadas para desafios específicos, requer alguma forma de descentralização para estabelecer contatos estreitos com os agricultores ${ }^{5}$ (CORREA; SCHMIDT, 2014, p. 8, tradução nossa).

Novos padrões tecnológicos, bem como novos padrões de consciência, também trazem diferentes dilemas, conflitos, atitudes que precisam ser conhecidas. De acordo com Rigamonti, Santos e Souza (2013, p. 305), "os saberes empíricos locais precisam ser organizados e sistematizados para facilitar a capilaridade, proporcionando avanços e fortalecimento do desenvolvimento de forma sustentável".

Na perspectiva do desenvolvimento sustentável como uma missão do Estado, Mussoi (1998), em sua tese de doutorado, indica que existe uma nova forma de atuar e indica a Investigação e Ação Participativa (IAP), a fim de chegar a um desenho institucional mais adequado, construído desde o princípio por agricultores, extensionistas e investigadores:

Assumindo a perspectiva do desenvolvimento sustentável como uma
missão de Estado (e tendo presente as dimensões básicas para o
desenvolvimento sustentável já discutidas) é possível encontrar uma nova
maneira de atuar [...] como metodologia geral para a atuação da
investigação e da extensão rural é proposto que se aprofunde em estudos à
respeito da Investigação e Ação Participativa (IAP) compreendendo-a não
apenas como uma "metodologia de investigação", mas também como uma
possibilidade de, a partir de sua aplicação, chegar a um modelo institucional

${ }^{5}$ Embrapa's institutional arrangements and policies-operational independence, sustained public investment in mission-oriented research, investment in human capital, and integration into international flow of knowledge- are certainly replicable across a variety of policy environments. Setting up a public research organization with a similar structure will require policy and continued financial support as well as focus on tangible, practical results. The customization aspect of Embrapa's operation, with researchers focusing on technologies that address specific challenges, requires some form of decentralization to establish close contacts with farmers ${ }^{5}$ (CORREA; SCHMIDT, 2014, p. 8). 
mais adequado. Por desenho institucional entende-se uma redefinição programática e principalmente uma redefinição organizacional. Se um processo de investigação-ação participativo tivesse o protagonismo efetivo dos agricultores, extensionistas e pesquisadores, a partir da análise da realidade, passando pela formulação e gestão conjunta dos projetos de investigação e socialização dos resultados, certamente poderia ser discutido um novo desenho institucional [...] frente a esta nova realidade (MUSSOI, 1998, p. 369-370) ${ }^{6}$.

Nota-se que é preciso promover mais pesquisas empíricas detalhadas e interdisciplinares, intensificar e aprofundar os debates entre todos os atores envolvidos (pesquisadores de universidades e instituições de pesquisa, agentes públicos e privados participantes das cadeias agroalimentares, atores sociais e econômicos vinculados a vida rural).

Mussoi acrescenta que a abordagem apresentada, além de gerar socialização dos conhecimentos, ainda capacita os protagonistas para uma nova maneira de atuar:

Ao mesmo tempo que a nova metodologia permitiria a implementação de um padrão inovador de desenvolvimento e produção/socialização de conhecimento, estaria também capacitando os protagonistas (pesquisadores, extensionistas e agricultores) para uma nova maneira de atuar. Trata-se também de uma escolha pedagógica. Seria um processo de aproximação gradual para um novo modelo, a uma nova concepção de desenvolvimento e de produção de conhecimento, e também "formação

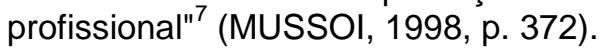

Em conformidade ao apresentado anteriormente, na perspectiva de Paulo Freire, Eliseu Alves e Adriana Bin, sobre a necessidade de maior aproximação entre cientistas e comunidades, Mussoi afirma que:

Esta dimensão participativa e que valoriza os saberes científicos e populares parece fundamental na realidade estudada. É necessário um método que, ao mesmo tempo que desmistifique a "superioridade de conhecimento", reconsidere a questão da "autoridade" e da "organização",

\footnotetext{
${ }^{6}$ Asumiéndose la perspectiva del desarrollo sustentale como una misión de Estado (y teniéndose presente las dimensiones básicas para el desarrollo sustentable ya discutidas) es posible buscar una nueva forma de actuar [...] como metodología general para la actuación de la investigación y de la extensión rural se propone que se profundice en estudios respecto a la Investigación y Acción Participativa (IAP), entendiéndola no sólo como una "metodología de investigación" sino también como una posibilidad de, a partir de su aplicación, llegar a un diseño institucional más adecuado. Por diseño institucional se entiende uma redefinición programática y principalmente una redefinición organizativa. Si um proceso de investigación-acción participativa tuviera el protagonismo efectivo de agricultores, extensionistas e investigadores desde el análisis de la realidad, pasando por la formulación y gestión conjunta de proyectos de investigación y socialización de los resultados, ciertamente podría ser discutido un nuevo diseño institucional [...], frente a esta nueva realidad (MUSSOI, 1998, pp. 369-370).
}

\footnotetext{
${ }^{7}$ Al mismo tiempo que la nueva metodología permitiría la implantación de um innovador patrón de desarrollo y producción/socialización de conocimientos, estaria también capacitando a los protagonistas (investigadores, extensionistas y agricultores) para una nueva forma de actuar. Se trata pues también de una opción pedagógica. Sería un proceso de aproximación gradual a un nuevo modelo, a uma nueva concepción de desarrollo y de producción de conocimientos, y también de "formación profesional" (MUSSOI, 1998, p. 372).
} 
com base na autoridade (seja administrativa ou científica) (MUSSOI, 1998, p. 371$)^{8}$.

No entanto, como desmistificar a superioridade dos saberes, se eles fazem parte de um processo de intervenção do Estado na agricultura, dentro de uma lógica capitalista? Aguiar (1986) evidencia que "o sistema nacional de pesquisa agropecuária - cujo órgão central é a Embrapa - constitui um instrumento que viabiliza uma dada estratégia de desenvolvimento capitalista" (p. 123). Ele explica que:

\begin{abstract}
O Estado põe-se, de fato, na origem do impulso da modernização, através do seguinte tripé: sistema nacional de pesquisa agropecuária, sistema brasileiro de assistência técnica e extensão rural e sistema nacional de crédito rural. Esses três instrumentos orbitam em torno do "pacote tecnológico". O primeiro é responsável por sua geração. O segundo pela sua difusão junto aos produtores. O terceiro pelo seu financiamento (aquisição de máquinas, de fertilizantes, de defensivos, de sementes, etc.). O "pacote tecnológico", portanto, constitui o vetor do processo de modernização (AGUIAR, 1986, p. 123).
\end{abstract}

A articulação dos mecanismos de intervenção do Estado na agricultura são também explicados por Aguiar (1986),

A necessidade de solicitação de créditos subsidiados obriga os produtores a atenderem a certas exigências burocráticas, entre as quais inclui-se a elaboração de um projeto técnico-financeiro. Esse projeto é, em geral, elaborado pela assistência técnica, que se encarrega também da administração e do acompanhamento da sua execução. Através desse projeto, os produtores comprometem-se a utilizar um "pacote tecnológico", seguindo todas as suas prescrições. Tal procedimento facilita a aceitação do projeto e, em consequência, a liberação dos recursos pelo estabelecimento bancário onde o crédito é solicitado. As normas e os critérios para aprovação do financiamento são definidos pelo sistema nacional de crédito rural (AGUIAR, 1986, p. 123-124).

A Embrapa, desde sua criação, foi concebida para atuar como um órgão central, com unidades de execução de pesquisa em diversos estados. Aguiar (1986) assinalou uma correlação entre a instituição e grandes centros internacionais:

[...] a criação desses centros nacionais por produtos representava a tentativa de reproduzir internamente as funções desempenhadas pelos grandes centros internacionais de pesquisa agropecuária, tais como 0 CIMMYT, sigla espanhola do Centro Internacional de Melhoramento de Milho e Trigo, situado no México, e o IRRI - Instituto Nacional de Pesquisa

\footnotetext{
${ }^{8}$ Esta dimensión participativa y valorizadora de los saberes científico y popular parece fundamental en la realidad estudiada. Es necesario un método que, al mismo tiempo que desmitifique la "superioridad de saberes", reconsidere la cuestión de la "autoridad" y de la "organización" en función de la autoridad (sea ella administrativa o científica) (MUSSOI, 1998, p. 371).
} 
do Arroz, localizado nas Filipinas, ambos criados e mantidos pela Fundação Rockefeller (AGUIAR, 1986, p. 45).

Ele continua seu raciocínio, esclarecendo em que bases se estabeleceu a cooperação técnico-científica na Embrapa, inclusive junto aos países africanos:

\begin{abstract}
É importante ressaltar, contudo, que a criação dos centros nacionais da Embrapa não visava apenas reproduzir no Brasil um desenho organizacional já testado a nível mundial. Muito mais importante que isso, a montagem interna de centros nacionais, à imagem e semelhança dos centros internacionais, buscava facilitar as articulações entre ambos, passando os últimos a fornecer material genético, equipamentos e referências técnicas e bibliográficas aos primeiros. Esse programa contínuo de intercâmbio tecnológico entre os centros internacionais e os centros nacionais viria incluir, mais adiante, a troca de informações sobre experimentos, o treinamento de pesquisadores brasileiros e a realização, tanto no Brasil como no exterior, de congressos e simpósios, entre outras formas de cooperação técnico-científica. No momento, esse programa de cooperação estabeleceu um novo circuito, que consiste precisamente no intercâmbio dos centros nacionais da Embrapa com os centros de pesquisa dos países africanos (AGUIAR, 1986, p. 48).
\end{abstract}

Por fim, associa o papel da Embrapa ao de grandes centros internacionais:

Portanto, muito mais que uma simples cópia de um modelo organizacional, estava-se diante da montagem de uma complexa e eficiente rede de transferência internacional de conhecimentos tecnológicos - ou, com mais rigor, de difusão internacional da capacidade de uso de determinados padrões tecnológicos -, à qual se associariam, também, os cursos de ciências agronômicas das universidades dos países desenvolvidos, especialmente dos Estados Unidos. Em tais cursos, os pesquisadores da Embrapa iriam buscar não só títulos acadêmicos, necessários à sua escalada funcional, como - sobretudo - um tipo de formação científica que Ihes desse os meios de adaptar os pacotes tecnológicos, cuja matriz básica é estabelecida pelos centros internacionais. Em síntese, enquanto os centros internacionais - criados, mantidos e administrados por corporações e fundações transnacionais, como a Ford Foundation, a Kellogg Foundation, a Rockefeller Foundation, o International Bank for Reconstruction and Develpment, entre outros - constituem os núcleos irradiadores dos pacotes tecnológicos a nível mundial, no plano interno esse papel passava a caber aos centros nacionais da Embrapa (AGUIAR, 1986, p. 48-49).

Por um lado, a conclusão óbvia seria que a Embrapa foi criada apenas como instrumento de uma estratégia política para fortalecer um sistema capitalista e ampliar o poder do Estado tanto em nível nacional como internacional. Desse modo, o uso dos pacotes tecnológicos não passa de mero mecanismo para fomentar bases monopolistas. Isso levaria a crer que o esforço ingênuo dos pesquisadores na busca de inovações tecnológicas aumentaria a desigualdade. Nessa perspectiva, a expansão transnacional de soluções agrícolas do Brasil para os países africanos seria apenas um meio de penetração de empresas multinacionais para exploração de novos mercados. 
No entanto, como apresentado no V Plano Diretor da Embrapa, "o futuro é um espaço aberto a múltiplas possibilidades, depositário de elementos predeterminados, mudanças em andamento e grandes incertezas" (EMBRAPA, 2008, p. 15). Enquanto algumas ações são focadas para a manutenção de um sistema que privilegia a lógica de mercado e beneficia um grupo de atores, outros perderam a fé e acreditam que qualquer ação contrária a essa lógica é uma verdadeira "perda de tempo". Há, ainda, quem, consciente ou inconsciente desse processo, fomente a ampliação da massa crítica. Aguiar (1986) desafiou-se a apresentar respostas na década de 1980 que explicam a historicidade da Embrapa e o contexto do sistema de pesquisa agropecuária. Porém, na década de 1970, Freire já visualizava o caminho da transformação ao afirmar que:

Rejeitar, em qualquer nível, a problematização dialógica é insistir num injustificável pessimismo em relação aos homens e à vida. É cair na prática depositante de um falso saber que, anestesiando o espírito crítico, serve à "domesticação" dos homens e instrumentaliza a invasão cultural (FREIRE, 1977, p. 55).

Cabral indica algumas estratégias, a partir da visão de Sílvio Crestana ${ }^{9}$, entre elas,

[...] colaborar na reconstrução e coordenação do SNPA10 no que tange ao papel federal e procurar viabilizar parceria mais eficiente com a extensão rural, assistência técnica pública e privada assim como com os serviços de extensão universitários (CABRAL, 2005, p. 243).

São vários os desafios referentes às políticas públicas, como a falta de marcos regulatórios e a melhoria ao acesso educacional, a fim de ampliar a capacidade de absorção e apropriação de conhecimento externo pelos agricultores, aumentando, assim, a inclusão produtiva. Será preciso, cada vez mais, buscar alternativas para atrair a mão de obra de jovens, em suas famílias, a fim de promover a sucessão geracional dos negócios. Porém, mais do que isso, é fundamental repensar o modelo de desenvolvimento agropecuário brasileiro, no intuito de garantir a sustentabilidade da agricultura e a segurança alimentar. Lembrar que, como disse Freire (1977),

\footnotetext{
${ }^{9}$ Sílvio Crestana: pesquisador da Embrapa, presidente entre 2005 e 2009.

${ }^{10}$ Sistema Nacional de Pesquisa Agropecuária (SNPA): foi instituído em 1992 pela Portaria no 193 (7/8/1992) do Ministério da Agricultura, autorizado pela Lei Agrícola (Lei no 8.171, de 17/1/1991). É constituído pela Embrapa, pelas Organizações Estaduais de Pesquisa Agropecuária - Oepas, por universidades e institutos de pesquisa de âmbito federal ou estadual, além de outras organizações públicas e privadas, direta ou indiretamente vinculadas à atividade de pesquisa agropecuária.
} 
Na modernização, de caráter puramente mecânico, tecnicista, manipulador, o centro da decisão da mudança não se acha na área de transformação, mas fora dela. A estrutura que se transforma não é o sujeito de sua transformação.

No desenvolvimento, pelo contrário, o ponto de decisão se encontra no ser que se transforma e seu processo não se verifica mecanicamente. Desta maneira, se bem que todo desenvolvimento seja modernização, nem toda modernização é desenvolvimento (FREIRE, 1977, p. 57).

A trajetória da Embrapa em pesquisa e transferência de tecnologia modelou o presente. A abordagem a ser formatada modelará o futuro. Queremos continuar transferindo pacotes tecnológicos, ainda que modernizemos seus nomes, para "aplicados" replicadores da tecnologia? Continuaremos transferindo daqui para ali, reforçando um sistema conservador? A Embrapa estaria disposta a ampliar o debate consciente e conscientizador dos agentes de mudança e torná-los coparticipes de uma transformação na maneira de atuar, ainda que isso provoque alterações no sistema? A Embrapa estaria aberta a mudar sua própria cultura verticalizada para se tornar coerente com seu novo discurso participativo e democrático?

Ainda que se imagine a possibilidade de reproduzir essa mesma abordagem linear: pesquisa, extensão rural, ela estaria constantemente no terreno da contradição. Porém, a partir da ampliação dos debates e da inclusão de novos atores no processo de desenvolvimento e inovação, vem se afirmando um olhar interdisciplinar sobre a realidade rural. O consumidor, a academia e o público em geral também assumem seu papel nesse cenário, indicando, com maior qualificação crítica, suas próprias demandas, não mais direcionadas, porém dialogadas, compartilhadas, intercambiadas.

O desafio da Embrapa é ampliado quando se percebe que aquela abordagem tecnicista, que colocou a Empresa em elevado patamar, está em risco, não somente por falta de maior, ou melhor, diálogo com os principais atores em agricultura. Além disso, embora tenha contribuído ativamente para melhorar os índices de segurança alimentar e nutrição no Brasil, a Embrapa poderia perder o espaço conquistado no cenário do desenvolvimento nacional se sua atuação não for apoiada por uma infraestrutura cada vez melhor e maiores investimentos em pesquisa e inovação.

A evolução do setor fez com que o Brasil deixasse de ser apenas importador, tornando-se um dos maiores exportadores de produtos agropecuários do mundo. Os avanços tecnológicos não podem ser freados, enquanto o País busca construir novas abordagens, tendo em vista o risco de perder competitividade. Atualmente, 
empresas privadas disputam o mercado, porque o percebem como promissor. Será preciso atuar de modo sistêmico, a fim de alavancar o uso de tecnologias e de novas práticas agrícolas, incluindo novas abordagens interdisciplinares, advindas da antropologia, sociologia e psicologia social e ampliando a cooperação com outros setores. Nesse sentido, Aguiar problematizou a questão relacionada ao uso de pacotes tecnológicos, enquanto Freire (1977) e Mussoi (1998) apontaram alternativas de diálogo com as comunidades. Salles e Bin (2014) levantaram questões contemporâneas, riscos e desafios que sugerem inovação, não apenas tecnológica, mas no modo de atuar das instituições de pesquisa.

Neste capítulo pretendeu-se rever o passado, focando na história da Embrapa, de forma a identificar os elementos centrais que a levaram a ser a empresa que é hoje. Pensar na abordagem da Embrapa em cooperação internacional sem conhecer seu passado é o mesmo que folhear um livro em branco, quando, na verdade, suas memórias estão disponíveis e impregnadas no seu presente, em publicações, em vozes expressas ou guardadas, que permeiam gerações. Com pouco mais de quarenta anos, a Embrapa já pode se considerar uma empresa madura o suficiente para rever sua forma de atuar, para quebrar paradigmas, reorientar decisões e transformar transformando a si mesma, de maneira profunda e continuada. 


\section{A EMBRAPA E OS PROJETOS DE COOPERAÇÃO TÉCNICA INTERNACIONAL}

\subsection{A Trajetória do Brasil na Cooperação Internacional para o Desenvolvimento}

\subsubsection{Conceituação e caracterização da CID, na perspectiva brasileira}

Antes de avançar na delimitação do contexto histórico sobre a trajetória do Brasil na Cooperação Internacional para o Desenvolvimento (CID), e principalmente na Cooperação Técnica entre Países em Desenvolvimento (CTPD) faz-se necessário clarificar os conceitos e percepções dessas práticas na opinião de alguns autores.

Segundo o cientista político e sociólogo espanhol José Ángel Sotillo, "não existe uma definição universal de cooperação internacional, além de uma elaborada pela Conferência dos Reitores das Universidades Espanholas (CRUE), em setembro de 2000" (SOTILLO, 2011, p. 58), a qual ele cita:

A Cooperação Internacional deve ser entendida como aquela modalidade de relações entre países que perseguem um benefício mútuo. A Cooperação para o Desenvolvimento é uma parte da Cooperação Internacional que, com propósito semelhante, estabelece-se entre países com diferentes níveis de desenvolvimento, com algumas finalidades específicas (consolidação democrática, desenvolvimento econômico e social sustentável, combate à pobreza, proteção do meio ambiente, entre outros) e toda estruturada em termos de corresponsabilidade entre as contrapartes. Neste sentido não deve ser confundido com a ajuda humanitária e, consequentemente, deve exigir um esforço dos parceiros, mas não podem ser os mesmos países em todos os países. Assim, o critério básico para a distribuição do esforço seria visar uma participação equilibrada, tanto em recursos pessoais como em recursos financeiros, de acordo com a situação real de cada parte (SOTILLO, 2011, p. 59, tradução nossa $)^{11}$.

Nessa definição, a cooperação internacional está associada à reciprocidade e interesses comuns. Ele acrescenta que é importante reconhecer a diferença entre cooperação internacional e ajuda humanitária.

\footnotetext{
${ }^{11}$ La Cooperación Internacional debe ser entendida como aquella modalidad de relaciones entre países que persiguen un beneficio mutuo. La Cooperación para el Desarrollo es una parte de la Cooperación Internacional que, con similar propósito, se establece entre países con distinto nivel de desarrollo, con unos fines concretos (consolidación democrática, desarrollo económico y social sostenible, lucha contra la pobreza, protección del medio ambiente, entre otros), y todo ello planteado en términos de corresponsabilidad entre las contrapartes. En ese sentido no debe confundirse con la ayuda humanitaria y, consecuentemente, debe exigir un esfuerzo de las contrapartes, aunque no puede ser el mismo en todos los países. De esta forma el criterio básico para el reparto del esfuerzo sería tender a una participación equilibrada, tanto en recursos personales como financieros, acorde con la situación real de cada parte (SOTILLO, 2011, p. 59).
} 
Por ajuda ao desenvolvimento entende-se a ajuda em dinheiro ou em espécie que os países ricos, sejam pessoas, instituições da sociedade civil ou governos, concedem aos países pobres, geralmente aos seus governos, mas também às instituições privadas e, por vezes, a indivíduos específicos ou grupos de indivíduos (para os refugiados, por exemplo). Auxílio de governo para governo é a ajuda oficial ao desenvolvimento (SOTILLO, 2011 , p. 61, tradução nossa) ${ }^{12}$.

\section{Da mesma forma, Robert Keohane distingue cooperação de harmonia e deixa claro que na cooperação existem políticas coordenadas para atingir um objetivo comum, enquanto na harmonia, uma das partes pode atingir seu objetivo ao acaso.}

Cooperação deve ser diferenciada de harmonia. Harmonia refere-se a uma situação em que políticas dos atores (desenvolvidas em seus próprios interesses, sem levar em conta outros) automaticamente facilitam a realização das metas dos outros. [...] Cooperação ocorre quando atores adequam seu comportamento para as preferências reais ou previstas de outros, através de um processo de coordenação política. Para resumir, mais formalmente, a cooperação intergovernamental toma lugar quando as políticas realmente seguidas de um governo são consideradas pelos seus parceiros como facilitar a realização dos seus próprios objetivos, como o resultado de um processo de coordenação das políticas (KEOHANE, 1984, p. 51-52, tradução nossa) ${ }^{13}$.

Segundo os antropólogos Daniel Simião e Kelly Cristiane da Silva,

A cooperação internacional para o desenvolvimento é, há algum tempo, uma das grandes forças atuantes na reconfiguração de estruturas políticas, locais e internacionais. Por meio dela, projetos construídos geralmente além-mar sobrepõem-se às mais diferentes realidades, interagindo (por vezes com maior ou menor flexibilidade) com agendas políticas e classificações sociais locais. O impacto e as consequências desses processos, contudo, estão bem para além do que normalmente vem escrito nas seções dos "objetivos" e "produtos" dos projetos de desenvolvimento patrocinados pelo campo da cooperação (SILVA; SIMIÃO, 2007, p. 11).

Para eles que acompanharam as ações de CID no Timor Leste, "a cooperação internacional constitui um vasto campo de poder por meio do qual ideias-valores imaginados como universais ganham feições locais" (SILVA; SIMIÃO, 2007, p. 11). Eles acrescentam, ainda, que:

\footnotetext{
${ }^{12}$ Por ayuda al desarrollo se entiende la ayuda en dinero o en especie que los países ricos, sean personas, instituciones de su sociedad civil o gobiernos, otorgan a los países pobres, normalmente a sus gobiernos, aunque también a instituciones privadas $Y$ algunas veces a personas concretas o grupos de personas (a los refugiados, por ejemplo). La ayuda de Gobierno a Gobierno es la ayuda oficial al desarrollo (SOTILLO, 2011, p. 61).

${ }^{13}$ Cooperation must be distinguished from harmony. Harmony refers to a situation in which actors' policies (pursued in their own self-interest without regard for others) automatically facilitate the attainment of others' .goals. [...] Cooperation occurs when actors adjust their behavior to the actual or anticipated preferences of others, through a process of policy coordination. To summarize more formally, intergovernmental cooperation takes place when the policies actually followed by one government are regarded by its partners as facilitating realization of their own objectives, as the result of a process of policy coordination (KEOHANE, 1984, pp. 51-52).
} 
[...] por trás do palco em que se encenava o espetáculo da modernização tecnicamente eficaz e politicamente asséptica, todo um cotidiano de tensões e disputas marcava as práticas dos cooperantes em busca de aplicação de seus modelos, práticas cujas consequências eram, inevitavelmente, cheias de imponderáveis (SILVA; SIMIÃO, 2007, p. 13).

Cabe destacar que Keohane também teorizou os conflitos em cooperação, mostrando que eles fazem parte das políticas intergovernamentais.

Cooperação, portanto, não implica uma ausência de conflito. Pelo contrário, ela é normalmente misturada com conflito e reflete esforços parcialmente bem sucedidos para superar conflitos, reais ou potenciais. A cooperação ocorre apenas em situações em que os atores percebem que suas políticas estão, atualmente ou potencialmente, em conflito, não onde há harmonia. $\mathrm{A}$ cooperação não deve ser vista como ausência de conflito, mas sim como uma reação ao conflito ou potencial conflito. Sem o espectro do conflito, não há nenhuma necessidade de cooperar (KEOHANE, 1984, p. 53-54, tradução nossa) ${ }^{14}$.

Milani acentua que:

[...] é evidente que, para além da polissemia dos termos empregados, muito frequentemente podem ser encontradas motivações políticas e jogos de poder nem sempre explicitados entre os atores envolvidos. Além disso, existe uma ampla variedade de contextos locais, cujas histórias nem sempre são consideradas para se saber o quão viável seria uma política pública local participativa. Afinal de contas, a participação tem custos e não pode ser dissociada da cultura política de cada sociedade em seu contexto histórico (MILANI, 2014, p. 38).

As citações de Silva e Simião (2007), Keohane (1984) e Milani (2014) deixam claro que o processo traz mais informações sobre a cooperação internacional do que seu próprio conceito. "O cenário da cooperação é bem mais complexo e multifacetado" (MILANI, 2014, p. 48).

Por outro lado, André de Mello e Souza afirma que

[...] parte da dificuldade em conceituar a CID decorre da maior complexidade e das transformações no conceito de desenvolvimento nacional. [...] O próprio conceito de desenvolvimento tem abandonado o foco primordial e exclusivo na renda para abarcar concepções mais holísticas, como a de desenvolvimento humano, proposta pelos economistas Amartya Sen, da Índia, e Mahbub ul Haq, do Paquistão (SOUZA, 2014, p. 14).

\footnotetext{
${ }^{14}$ Cooperation therefore does not imply an absence of conflict. On the contrary, it is typically mixed with conflict and reflects partially successful efforts to overcome conflict, real or potential. Cooperation takes place only in situations in which actors perceive that their policies are actually or potentially in conflict, not where there is harmony. Cooperation should not be viewed as the absence of conflict, but rather as a reaction to conflict or potential conflict. Without the specter of conflict, there is no need to cooperate (KEOHANE, 1984, pp. 53-54).
} 
A CTPD, objeto desse estudo, "é um instrumento de política externa e de promoção do desenvolvimento internacional dos países não-alinhados, criado ao final dos anos 1970" (ALMEIDA; CAMPOS, 2010, p. 25), cujo objetivo principal é compartilhar conhecimentos, técnicas e tecnologias testadas e validadas no Brasil, adaptando-as para os países beneficiários.

Segundo o relatório do COBRADI,

A cooperação técnica internacional do governo brasileiro visa à capacitação
de indivíduos e ao fortalecimento de organizações e instituições no exterior.
A essência do seu processo é a transferência e o compartilhamento de
conhecimentos e tecnologias nacionais com potencial de adaptação,
absorção e geração de impactos positivos no desenvolvimento autônomo de
outros países (IPEA; ABC, 2013, p. 25).

De forma geral, a CTPD do país, também conhecida como Cooperação Sul-Sul (CSS) ou Cooperação Horizontal, é estabelecida entre o governo do Brasil e os governos de outros países, em parceria com várias instituições governamentais brasileiras, sob a coordenação da Agência Brasileira de Cooperação do Ministério das Relações Exteriores (ABC/MRE).

As modalidades de cooperação variam entre bilateral, triangular e multilateral. A diferenciação é dada pelo número de países envolvidos na cooperação. A cooperação triangular, modalidade do caso em estudo, i.e. do projeto ProSavana, é definida por Sotillo como uma "modalidade em que um país doador direciona sua ajuda a um país- parceiro por meio de um terceiro país-parceiro - país em desenvolvimento - que atua como um país-líder na canalização dos recursos dos vários países doadores" (SOTILLO, 2011, p. 76, tradução nossa) ${ }^{15}$. Nesse caso específico, a atuação ocorre entre Brasil, Japão e Moçambique.

\subsubsection{O surgimento da CTPD}

Poucos anos depois do fim da Segunda Guerra Mundial, à medida que as nações atingidas recomeçavam a desenvolver sua economia, suas sociedades se deparavam com modelos inovadores de produtos, serviços, tecnologias e formas de comercialização. As duas grandes potências da época, os Estados Unidos e a União Soviética, aliaram-se a vários países a fim de conduzir o desenvolvimento

\footnotetext{
${ }^{15}$ Modalidad en la que un país donante dirige sus ayudas a un país socio por medio de un tercer país socio país en desarrollo- que actúa como país líder en la canalización de los recursos de varios países donantes" (SOTILLO, 2011, p. 76).
} 
internacional nas suas respectivas esferas de influência ideológica: capitalismo e comunismo, respectivamente. De acordo com a vertente capitalista, o crescimento econômico impulsionaria o desenvolvimento da sociedade. Por outro lado, o comunismo apregoava o estabelecimento de uma sociedade igualitária, sem classes sociais (LEITE, 2012).

Nesse embate de potências conhecido como "Guerra Fria", entre o final da Segunda Guerra Mundial (1945) e a extinção da União Soviética (1991), afirmam-se as relações internacionais por meio da Cooperação Norte-Sul (CNS), mediante a qual os países desenvolvidos do hemisfério norte ajudavam países em desenvolvimento do hemisfério sul, por meio da transferência de recursos materiais, financeiros, humanos e tecnológicos (LEITE, 2012). As bases da CNS remontam aos acordos de Bretton Woods, em 1944, que estabeleceram os pilares econômicos da nova ordem internacional: a Organização Mundial do Comércio (OMC) para regular o sistema comercial internacional; o Banco Mundial e o Banco Internacional para Reconstrução e Desenvolvimento (BIRD), para promover a reconstrução dos países europeus devastados pela guerra (Reino Unido e França, entre outros) e o desenvolvimento da América Latina (principalmente); e o Fundo Monetário Internacional (FMI), para garantir a segurança financeira dos países e viabilizar seus investimentos públicos.

Em princípio, a atuação dessas instituições era mais pensada na vertente Norte-Norte que Norte-Sul. Nos anos sucessivos, enquanto retomavam o rumo do crescimento econômico (apoiados, também, pelo Plano Marshall, a partir de 1947), os países europeus começavam a perder influência e poder em suas colônias na África e na Ásia, onde ganhavam força os movimentos independentistas. Nesse contexto, a Organização das Nações Unidas (ONU), criada em 1945, logo após a segunda guerra mundial (antes da emergência dos fenômenos de descolonização), promoveu, de acordo com sua Carta, a "cooperação internacional para resolver os problemas internacionais de caráter econômico, social, cultural ou humanitário, e para promover e estimular o respeito aos direitos humanos e às liberdades fundamentais para todos, sem distinção de raça, sexo, língua ou religião ${ }^{16 " ~(O N U, ~}$ 2015, tradução nossa).

\footnotetext{
${ }^{16}$ To achieve international co-operation in solving international problems of an economic, social, cultural, or humanitarian character, and in promoting and encouraging respect for human rights and for fundamental freedoms for all without distinction as to race, sex, language, or religion.
} 
A própria Carta das Nações Unidas, entre seus princípios universais, assinados também por países que ainda mantinham colônias na Ásia e na África, reconhecia o direito à autodeterminação dos povos colonizados. A partir da descolonização da África e da Ásia, concomitante aos anos mais intensos da guerra fria, a Cooperação Internacional se torna, de fato, um mecanismo de contenção do socialismo soviético pelo bloco capitalista. "A luta anticomunista serviu de elo importante entre a CID e as agendas da política externa dos Estados Unidos" (HOOK ${ }^{17}, 1995$ apud MILANI, 2014, p. 35).

De acordo com Milani,

[...] teoricamente, os anos 1950 e 1960 assistiram à consolidação de um desenvolvimentismo estreitamente associado ao keynesianismo e à ideia de modernização. Os países foram classificados (desenvolvidos e subdesenvolvidos) (MILANI, 2014, p. 35).

André de Mello e Souza distingue esses países entre doadores e recipiendários:

\begin{abstract}
A partir dos anos 1960, os países-membros do Comitê de Assistência ao Desenvolvimento (CAD), da Organização para a Cooperação Econômica e Desenvolvimento (OCDE) - cujas origens remontam à CID na forma do Plano Marshall -, passaram a ser conhecidos como doadores tradicionais, conquanto os países do chamado terceiro mundo - ele mesmo um grupamento altamente heterogêneo - eram identificados como recipiendários (SOUZA, 2014, p.11).
\end{abstract}

Com base em padrões exclusivamente econômicos, a causa do subdesenvolvimento era atribuída à escassez de capital e de conhecimentos técnicos para a industrialização, cabendo aos doadores suprir essas necessidades. Sucede a esse momento um período marcado por pressões ao setor agrícola, devido à publicação de obras de economistas que sugeriam a industrialização atrelada ao desenvolvimento das áreas rurais. Estas forneceriam alimentos, trabalho e capital para o setor industrial, além de servir de mercado para produtos industriais locais e gerar divisas em moeda externa, por meio de exportações, de forma a viabilizar as importações necessárias para o avanço industrial (LEITE, 2012).

Em 1955, 29 países recém-independentes da Ásia e da África reuniram-se na Conferência de Bandung, na Indonésia, "convocada pelos governos de Birmânia, Ceilão, Índia, Indonésia e Paquistão" (MILANI, 2014, p. 36). "Foi um dos primeiros passos da cooperação política entre países em desenvolvimento a fim de combater as diferentes versões do colonialismo e da dominação ocidental, em nome da

\footnotetext{
${ }^{17}$ HOOK, S. National interest and foreign aid. Boulder: Lynne Rienner, 1995.
} 
solidariedade entre os países do Terceiro Mundo" (MILANI; CARVALHO, 2013, p. 13), e, além disso, ter mais voz no cenário internacional.

Em seguida, a partir de uma conferência internacional em Belgrado em 1961, vários dos países participantes da Conferência de Bandung e outros do hemisfério sul, originaram o Movimento dos Países Não Alinhados (MPNA), defendendo a Cooperação Sul-Sul em complementação à cooperação Norte-Sul, dominada pelos blocos geopolíticos que tinham como referência os polos de influência do eixo LesteOeste, i.e. União Soviética e Estados Unidos da América. Com o golpe de 1964, o Brasil acabou por participar timidamente desse movimento.

Nos anos 70, começa a ser percebido que os influxos de capital, por insuficiência ou por gestão ineficiente, ou, ainda, por questões endógenas adequadas, não conseguem prover os países em desenvolvimento (PED), das condições necessárias para o desenvolvimento e quiçá para a autossuficiência (PUENTE, 2010).

Em 1978, "a Conferência de Buenos Aires foi o primeiro esforço coletivo de identificação e de sistematização das formas, modalidades e possibilidades da cooperação técnica entre países em desenvolvimento" (PUENTE, 2010, p. 78). De acordo com o Plano de Ação de Buenos Aires, resultante dessa Conferência, a CSS era um processo consciente, sistemático e politicamente motivado, que surgiu a princípio como um complemento da CNS, promovendo perspectivas próprias dos países do hemisfério sul, a partir de um modelo baseado nas realidades e necessidades dos próprios países envolvidos, sem imposição de condições por parte dos países do hemisfério norte.

De acordo com Pino e Leite,

[...] essa modalidade de cooperação passou a ser vista como mais eficiente na promoção do desenvolvimento por três razões principais: pela maior aplicabilidade de soluções concebidas nos países do Sul (é o caso, por exemplo, da tecnologia para a produção de alimentos em zonas tropicais, desenvolvida nos países localizados nessa região); pelo deslocamento das atividades de pesquisa nos países industrializados para o setor privado, impossibilitando sua transferência gratuita ou a baixo custo; pela ausência ou grau reduzido das condicionalidades (macroeconômicas ou de governança) ligadas à assistência provida pelos países em desenvolvimento (PINO; LEITE, 2009, p. 17).

Conforme resumido por De Renzio, et al., desde o lançamento do Plano de Ação de Buenos Aires, 
[...] líderes regionais como Brasil, Índia e China vieram a ocupar uma posição estratégica na articulação entre os países do Sul e ensejam um novo modelo de cooperação, supostamente estruturado a partir dos princípios da horizontalidade e da não imposição de condicionalidades, e orientado pelas demandas e necessidades do país parceiro (DE RENZIO, et al., 2013, p. 2).

Segundo MILANI, (2014, p. 42) "os anos 1990, marcados pelo fim da ordem da Guerra Fria e pela aceleração dos processos de globalização, prometiam um mundo mais pacífico em que a cooperação para o desenvolvimento seria prioritária". No entanto, "somente a partir de 2004, a CTPD passou a ser referida oficialmente, no âmbito das Nações Unidas, também como Cooperação Sul-Sul” (PUENTE, 2010, p. 79).

A conjuntura política e econômica desses anos representa um importante ponto de inflexão para a CSS e para consolidar a reinserção do Brasil no sistema internacional. Tanto a geopolítica global pós-Guerra Fria, quanto o processo político e econômico nacional (estabilidade democrática e econômica, participação da sociedade civil e políticas sociais mais inclusivas) poderiam denotar um momento de oportunidades para o Brasil (ALMEIDA; CAMPOS, 2010).

Assim, por meio da CSS, os países emergentes no cenário político internacional buscam um desenvolvimento conjunto, principalmente mediante o compartilhamento de melhores práticas. Nessa ótica, a transferência de conhecimentos de um país para outro é concebida como uma forma de promover o desenvolvimento internacional sem prejudicar a soberania nacional. Além disso, pode ser uma alternativa para reduzir a dependência de programas de ajuda oferecidos pelos países desenvolvidos, que implicavam a aceitação de condições políticas e econômicas que, de forma mais discreta, perpetuavam o modelo de subordinação colonial. Essa nova abordagem de cooperação, de natureza horizontal por ser estabelecida entre países afins do mesmo hemisfério, exige o espírito de solidariedade e o respeito à diversidade e à pluralidade, com ênfase na conexão entre o desenvolvimento econômico, social, ambiental e cultural.

\subsubsection{Características atuais da CTPD brasileira}

O papel do Brasil na CTPD vem ganhando destaque e importância no contexto global há mais de duas décadas. O desenvolvimento econômico e social brasileiro após o Plano Real, iniciado oficialmente em 30 de julho de 1994, no Governo de 
Fernando Henrique Cardoso, elevou o status do país no cenário da Cooperação Internacional. A própria experiência como país recebedor de Assistência Oficial para - Desenvolvimento (AOD) nas décadas anteriores à atual, preparou o Brasil para assumir um novo posicionamento estratégico nas relações com nações do hemisfério norte que tradicionalmente prestam CTPD, tais como Estados Unidos, Alemanha, Japão e Reino Unido; e buscar um formato distinto de atuação com países em desenvolvimento e com os países do Norte.

No âmbito das Relações Internacionais, o Brasil já era respeitado desde o início do século XX. Sua atuação na conferência de São Francisco em 1945, e a presidência da Assembleia Geral que determinou a criação do estado de Israel são dois bons exemplos. O fácil trânsito da diplomacia brasileira entre praticamente todos os países e a reconhecida competência do corpo diplomático do MRE construíram uma sólida imagem de isonomia e idoneidade do Brasil pelos países em desenvolvimento.

Precursor das relações com a África foi Adalberto Camargo, o primeiro negro a alçar o Congresso Nacional, como deputado federal de São Paulo em 1967, reeleito em 1970, '74 e '78. Foi o primeiro parlamentar no Brasil a trazer para o debate político algumas questões sobre a África, ainda durante o bipartidarismo. Ele começou a desenvolver o relacionamento entre Brasil e África em 1962. Isto porque entre 1958 e 1962 a maioria dos países africanos se tornou independente. Em decorrência desse compromisso, criou a Câmara de Comércio Brasil-África e foi membro da Comissão de Relações Exteriores do Congresso Nacional, durante dez anos. O retorno ao pluripartidarismo reuniu no mesmo partido o futuro presidente e 0 congressista. Conforme afirmou em depoimento:

[...] Eu fui buscar o que é mais importante para a ascensão do negro no Brasil, a África. Árvore sem raiz não dá fruto. Hoje esse povo está sentado nas grandes mesas de decisão da sociedade mundial e consequentemente os seus descendentes de fora da África têm que sentar nas mesas de decisão dos países que ajudaram a erigir (VALENTE, 1986, p. 170).

No campo da cooperação internacional, a atuação cada vez mais protagonista e proativa do Brasil nas principais negociações internacionais desde o início dos anos 2000, principalmente naquelas referentes a meio ambiente e comércio, pode ser explicada pela vontade do país de mudar as regras da velha geopolítica. Diante dessa perspectiva de dominação dos países desenvolvidos do hemisfério norte 
(principalmente Estados Unidos e países europeus), o governo brasileiro privilegiou as dinâmicas horizontais de política externa. Aliou-se de preferência a outros países do hemisfério sul, desafiando assim as dinâmicas verticais no sentido norte-sul. Afinal, fortalecendo importantes relações horizontais de sul a sul no tabuleiro da geopolítica dos anos 2000, o Brasil tornou-se um "jogador experiente" na política internacional. Ganhou maior representatividade e passou a ser respeitado pelos países do hemisfério norte, principalmente pela sua capacidade de interação diplomática com países da África e da Ásia.

Nesse sentido, mecanismos de CTPD desenvolvidos pelo Brasil para transferir algumas das suas experiências mais exitosas de política pública nacional para outros países do hemisfério sul vêm sendo cada vez mais utilizados pelo governo brasileiro em complementação e substituição aos mecanismos tradicionais. Essa dinâmica é também refletida pela evolução e substituição das palavras utilizadas no "jogo antigo" da CTPD, onde o tabuleiro era constantemente dominado pelos países do hemisfério norte. Nesse "novo jogo", ao invés de países doadores e recebedores, fala-se em "países cooperantes" ou "parceiros" e as "parcerias de cooperação" substituíram as antigas atividades ou iniciativas de "ajuda" ou "assistência" oficial. É importante observar que a mudança no discurso ainda não significa, na mesma proporcionalidade, uma mudança na prática da cooperação.

Se a presidência de Fernando Henrique Cardoso propiciou uma maior aproximação entre os países do sul, e conferiu uma fase progressiva de desenvolvimento econômico e estabilidade governamental em âmbito doméstico, foi a partir do governo de Lula que o Brasil aumentou sua atuação como país provedor de CTPD, cujo objetivo principal é compartilhar conhecimentos, técnicas e tecnologias testadas e validadas para políticas públicas no Brasil, adaptando-as para os países beneficiários.

Em particular, a partir de 2003, durante a presidência de Lula, a agenda proposta para a política externa brasileira destacava a necessidade de reforçar uma política Sul-Sul com países emergentes em busca de um entendimento global baseado no diálogo e não no uso do poderio militar, econômico e político, traço essencial da política externa brasileira em toda a história do país (IPEA; BANCO MUNDIAL, 2011). Nesse sentido, o Brasil estabeleceu coalizões e parcerias de cooperação com potências emergentes no cenário internacional, tais como Índia, 
China, Rússia e África do Sul, e com os países de língua portuguesa na África e na Ásia.

Na gestão da Presidente Dilma Rousseff, entre 2010 e 2014, as ações de CTPD foram drasticamente reduzidas, principalmente em consequência de sucessivos cortes de recursos no orçamento da ABC.

Cabral et al. (2013) comparam a gestão Lula com a abordagem da gestão Dilma, sugerindo uma atitude mais pragmática da atual Presidente.

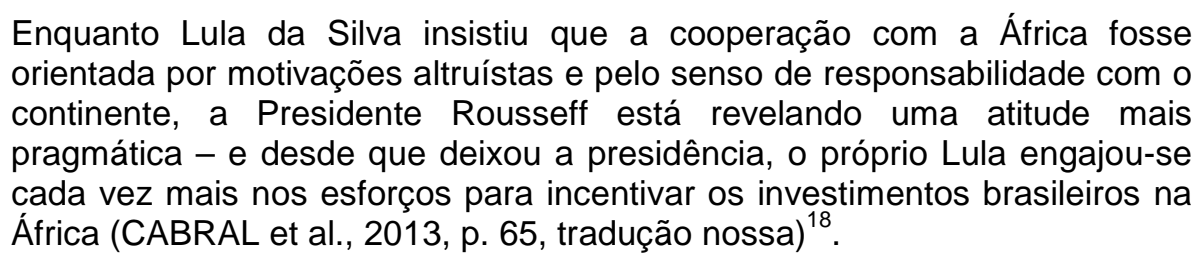

Ainda que de maneira reduzida, nos últimos anos, o país tem priorizado a CSS, principalmente no continente africano. Por meio de várias modalidades, incluindo variações mais ou menos complexas da tradicional cooperação bilateral - como a cooperação trilateral, ou triangular, e multilateral - estabelece-se uma relação direta com o país beneficiário. Às vezes essa relação é mediada ou integrada por outro país doador, geralmente do hemisfério norte, ou por grupos de países. Nessa situação são incluídas instituições estrangeiras, entre elas a Agência de Cooperação Internacional do Japão (JICA), a Agência dos Estados Unidos para o Desenvolvimento Internacional (USAID), o Ministério Britânico para o Desenvolvimento Internacional (DFID) e o Instituto Interamericano de Cooperação para Agricultura (IICA).

Como reflexo das diretrizes gerais da política externa formuladas pelo Governo Federal, o Brasil tem intensificado relações de cooperação com um crescente número de países nas Américas, na África e na Ásia. Enquanto o País tem priorizado, internamente, a promoção da inclusão social, no plano internacional busca atender várias demandas de países em desenvolvimento, no intuito de contribuir para a redução da pobreza e da fome e, ao mesmo tempo, consolidar-se como um ator protagonista na mutável ordem global (ABC, 2011).

Contini e Martha Júnior (2013) destaca alguns pontos que explicitam a importância de se apoiar o processo:

\footnotetext{
${ }^{18}$ While Lula da Silva insisted that cooperation with Africa was driven by altruistic motivations and a sense of responsibility toward the continent, President Rousseff is revealing a more pragmatic attitude - and since leaving the presidency Lula himself has become increasingly associated with efforts to encourage Brazilian investment in Africa (CABRAL et al., 2013, p. 65).
} 
No campo político, não há dúvidas de que o grau (mediano) de desenvolvimento alcançado nos últimos anos, "autoriza" o Brasil a pleitear um posicionamento mais forte no cenário mundial, incluindo postos-chaves em órgãos internacionais (...) O Brasil passou a visualizar também que países da África estão em processo de desenvolvimento, incluindo a agricultura (THE ECONOMIST, 2012). A presença hoje representará maior reconhecimento político e oportunidades de negócios no futuro. Quem não se fizer presente hoje, terá dificuldades no futuro de participar dos benefícios do desenvolvimento. Não é questão de domínio político ou econômico (CONTINI; MARTHA JÚNIOR, 2013, p. 3).

O Brasil aproximou-se da África principalmente em decorrência dos vínculos históricos, geográficos e culturais com vários países africanos, devido ao seu passado de país-colônia do reino de Portugal, o qual, por sua vez, entre os séculos XIV e XX, também manteve várias colônias na África. A língua e a história em comum têm facilitado a aproximação política e diplomática entre as ex-colônias de Portugal. Principalmente por causa desses vínculos, o Brasil tem voltado grande parte das suas atenções recentes para os PALOP, que se tornaram os principais destinatários da cooperação técnica brasileira.

A identificação de vários países africanos como parceiros do Brasil no âmbito da CTPD também se justifica com base em dados do Relatório de Desenvolvimento Humano de 2013, elaborado pelo Programa das Nações Unidas para o Desenvolvimento - PNUD. Nesse relatório foi apresentado que:

Em 2012, o valor global médio do IDH foi 0,694; a África Subsaariana apresentou o mais baixo IDH, que se situou em 0,475 , seguida pela Ásia do Sul, com 0,558. Entre as regiões em desenvolvimento, as que registraram o maior IDH foram a Europa e Ásia Central $(0,771)$, seguidas da América Latina e das Caraíbas (0,741) (PNUD, 2013, p. 23).

De acordo com dados do Banco Mundial, a renda média anual per capita da África subsaariana foi estimada em 952 dólares americanos em 2007. Embora esse valor seja um pouco mais elevado do que os 880 dólares do Sul Asiático (Afeganistão, Bangladesh, Butão, Índia, Maldivas, Nepal, Paquistão e Sri Lanka), é ainda mais baixo do que o de qualquer outra região do mundo (CHANG, 2013).

$\mathrm{Na}$ África, em particular, o Brasil tornou-se o quarto país mais presente, considerando as embaixadas e consulados ali instalados, perfazendo um total de 37 . Apenas Estados Unidos, China e Rússia ultrapassam esse número. Essa expansão diplomática do Brasil para a África também tem provocado um aumento no número das embaixadas africanas no Brasil: de 2003 a 2012 saltou de 16 para 33 países representados (MRE, 2011 apud CABRAL, 2011). 
Em termos de volume de recursos investidos pela cooperação técnica oficial brasileira, os PALOP foram beneficiados com $74 \%$ do total de recursos destinados ao continente (CABRAL, 2011). Em 2011, foram registrados projetos de cooperação técnica em 38 países. Moçambique é atualmente o principal país beneficiário de projetos de cooperação (MRE, 2011; ABC ${ }^{19}, 2011$ apud CABRAL, 2011).

Embora esse seja o retrato de um momento, o fluxo constante nos planos geopolítico, econômico, social, cultural, demográfico e geofísico tem repercussões para o domínio da cooperação internacional, tanto em termos de atores polos de influência e volumes de recursos disponíveis, quanto em prioridades de atuação (CABRAL, 2013). Isso afeta as instituições que precisam se organizar conforme as mudanças nas agendas de governo.

A cooperação técnica oficial, que é prestada por meio de órgãos e entidades do governo brasileiro, concentra-se em três setores principais: agricultura, saúde e educação. Em particular, o setor da agricultura absorveu $26 \%$ do volume total de recursos despendidos para a cooperação técnica no período 2003-2010 (ABC, 2011).

\subsection{A Trajetória da Embrapa na CTPD}

As iniciativas em prol da cooperação internacional da Embrapa são tradicionais na empresa e vêm sendo desenvolvidas desde sua fundação. Com o funcionamento dos Laboratórios Virtuais no Exterior (Labex), a Empresa relaciona-se com pesquisadores em diferentes instituições do mundo.

No Brasil, a Embrapa tem sido a principal entidade do governo brasileiro para a execução da CTPD, principalmente, a partir de 2006, com a instalação da Embrapa África em Acra, Gana, no âmbito de uma iniciativa conhecida como Projeto Embrapa África, com intuito de aprimorar as práticas de agricultura e reduzir a pobreza no continente.

Em 2007, várias parcerias foram firmadas com instituições brasileiras e internacionais, com o objetivo de trocar experiências em prol da agropecuária brasileira. Embrapa e Basf assinaram acordo de cooperação para incrementar a biotecnologia vegetal no Brasil. A Embrapa e o Centro Francês de Cooperação

\footnotetext{
${ }^{19}$ ABC. Brazilian technical cooperation. Brasília: Agência Brasileira de Cooperação, Ministério das Relações Exteriores, 2011.
} 
Internacional em Pesquisa Agropecuária para o Desenvolvimento - CIRAD assinaram uma carta de intenções para a criação do Consórcio Internacional em Biologia Avançada - CIBA para gerenciar os esforços de pesquisa entre a Embrapa e o Agropolis - Polo de Pesquisa Em Agronomia Tropical e Mediterrânea, situado em Montepellier, na França (A EMBRAPA..., 2007). Segundo o informativo GeneBio, elaborado pela Embrapa Recursos Genéticos e Tecnologia, a cooperação entre a Embrapa e o CIRAD na área técnica tinha mais de trinta anos, com muitos resultados positivos para a agricultura tropical e subtropical, com avanços nas áreas de biologia e genômica funcional (A EMBRAPA..., 2007). A Embrapa mantém parcerias de cooperação há muito tempo com outras instituições estrangeiras, tais como a JICA, o IICA, entre outros.

No Gana, a Embrapa desenvolve projetos de uso sustentável de recursos naturais, sistemas produtivos e proteção sanitária de plantas e animais, fruticultura e horticultura tropical, zoneamento agrícola, biotecnologia e troca de material genético. Cláudia Izique, em artigo na Revista FAPESP, esclarece as distintas modalidades de cooperação da Embrapa na África Subsaariana e enfatiza que em Moçambique, Angola e Guiné-Bissau, a atuação da Embrapa tem caráter de cooperação humanitária e obedece a uma agenda triangular, cuja capacitação de pessoal ou transferência de tecnologia é financiada por terceiros. Nesse sentido, ela menciona que a JICA financiou o programa de apoio à produção de caju e de leite na GuinéBissau (IZIQUE, 2008). Em entrevista para a mesma revista, Sílvio Crestana, presidente da Embrapa entre 2005 e 2009, enfatizou: "A nossa agenda internacional tem grande repercussão na política externa do Brasil" (IZIQUE, 2008, p. 34).

A articulação dos projetos de cooperação internacional técnica ou científica é realizada em apoio à $A B C$, a partir da Secretaria de Relações Internacionais - SRI, que a operacionaliza por meio de parcerias com as Unidades Descentralizadas UDs da Empresa, conforme o foco específico de sua atuação. A estrutura da Empresa é composta de quinze unidades centrais, localizadas em Brasília, e 47 Unidades Descentralizadas, em todas as regiões do Brasil. A Empresa também busca cooperação com os principais centros de pesquisa mundiais, por meio de quatro Laboratórios Virtuais no Exterior (Labex), nos Estados Unidos da América, Europa, China e Coréia do Sul e três escritórios regionais, na América Latina e África (EMBRAPA, 2014b). 
Os principais instrumentos de cooperação técnica utilizados em sua atuação internacional são: (1) projetos estruturantes; (2) projetos de menor porte ou curta duração, de acordo com a política externa do MRE e sob coordenação da ABC; (3) a Plataforma de Inovação Agropecuária (Agricultural Innovation Marketplace) e (4) os cursos de capacitação em agricultura tropical, realizados no Brasil e no exterior (EMBRAPA, 2014c).

Os projetos estruturantes são projetos de desenvolvimento executados em parceria com um país ou um grupo de países africanos, latino-americanos ou caribenhos, para o fortalecimento das suas bases tecnológicas e institucionais e de recursos humanos necessários ao desenvolvimento sustentável da agricultura. Esses projetos incluem componentes complementares nas áreas de validação e transferência de tecnologias, fortalecimento de instituições de pesquisa e capacitação de profissionais. São projetos com um volume relativamente alto de recursos financeiros (superior a um milhão de dólares americanos) e com mais de dois anos de duração. Geralmente, esses projetos contam com a presença permanente de um profissional da Embrapa no país para a coordenação local das atividades (EMBRAPA, 2014d).

Desde 2009, a Embrapa atua na África, por meio dos programas e projetos apresentados a seguir:

Apoio ao Desenvolvimento da Rizicultura no Senegal, o qual teve como objetivo principal o aumento da competitividade da cadeia produtiva do arroz no Senegal (ABC, 2014). Iniciado em julho de 2010 e concluído em março de 2013, buscou revitalizar e equipar as estações experimentais de Serigne Moustapha Bassirou Mbacké, ex Ndiol e Fanaye, localizadas no vale do Rio Senegal, e de Casamance, no sul do Senegal, para que passassem a funcionar como Unidades Piloto de Pesquisa Adaptativa e de Demonstração de tecnologias inovadoras. Este projeto também apoiou a pesquisa adaptativa nas áreas de testes varietais, solos/nutrição e manejo integrado de pragas. Além disso, o projeto fortaleceu as capacidades de pesquisadores, técnicos e agricultores líderes do Senegal em tecnologias de produção e transformação de arroz; e transferiu conhecimentos validados em produção e transformação de arroz aos técnicos de extensão rural e agricultores no Senegal. A ABC investiu neste projeto aproximadamente US\$ 1.840 .000 . 
O Programa Embrapa-ABC Moçambique visa fortalecer o setor agropecuário por meio da adaptação de tecnologias brasileiras às condições específicas do país, promovendo o desenvolvimento institucional do Instituto de Investigação Agrária de Moçambique (IIAM) e a capacitação do seu quadro técnico. Este Programa é composto por três projetos:

Projeto Plataforma, que visa fortalecer o Sistema de Investigação Agropecuária de Moçambique, de modo a promover a disseminação de tecnologias agropecuárias e o planejamento, a coordenação, o controle e a avaliação de ações de investigação. Além de fortalecer o IIAM, esse Projeto busca estabelecer o Sistema de Sementes e o Sistema de Gestão Territorial; estabelecer comunicação e informação para a transferência de tecnologia; e desenvolver e implementar o modelo de gestão, acompanhamento, monitoria e avaliação da investigação agropecuária. O projeto, que conta com um orçamento de aproximadamente doze milhões de dólares, foi iniciado em maio de 2010 e tem seu término previsto para dezembro de 2014;

O ProsavanA - Pl, Projeto de Melhoria da Capacidade de Pesquisa e de Transferência de Tecnologia para o Desenvolvimento da Agricultura no Corredor de Nacala, visa aumentar a produção agrícola em Moçambique. Iniciado em 2011 e com término previsto para 2016, tem como fonte de recursos os governos do Brasil, por meio da $A B C$, do Japão, via Agência de Cooperação Internacional do Japão (JICA), e de Moçambique, representado pelo IIAM (EMBRAPA, 2014b). Este é o projeto de CTPD da Embrapa com o maior orçamento (mais de US\$ 14 milhões);

O Projeto Segurança Alimentar, ou Projeto de Apoio Técnico aos Programas de Nutrição e Segurança Alimentar, tem como finalidade aumentar e diversificar a produção de hortaliças da agricultura familiar e ampliar a oferta de alimentos, por meio de novas tecnologias de cultivo (EMBRAPA, 2014f). O projeto, que conta com quase dois milhões e meio de dólares de orçamento, foi iniciado em outubro de 2011 e tem o término previsto para outubro de 2014. O foco principal desse Projeto é desenvolver e fortalecer sistemas de produção, visando ao aumento qualitativo e quantitativo da produção de produtos hortícolas como instrumentos de diversificação da dieta alimentar em Moçambique. O Projeto também visa desenvolver e fortalecer modelos integrados de produção agrícola, pós-colheita e processamento de produtos estratégicos, além de melhorar os sistemas de embalagem, armazenagem e processamento de produtos hortícolas para suporte aos programas de segurança 
alimentar e nutricional. Os objetivos específicos deste Projeto incluem: capacitar o corpo técnico especializado na área de extensão e pesquisa em Moçambique, aprimorando seu conhecimento técnico em sistemas de produção, pós-colheita e processamento de hortaliças e de gestão de unidades coletivas de produção e processamento de produtos agroalimentares; gerar uma base de conhecimento sobre produção, pós-colheita e processamento de hortaliças para delineamento das particularidades da produção e do consumo de hortaliças em Moçambique e avaliação das tecnologias, dos produtos e dos processos a serem transferidos no âmbito do projeto.

O Cotton 4 ou C4, iniciado em 2009 e finalizado em 2013, visava desenvolver a cotonicultura em Benin, Burkina Faso, Chade e Mali. Seus objetivos específicos incluíam: revitalizar a Estação Experimental de Sotuba existente em Bamako, Mali, para funcionar como Unidade Piloto de Pesquisa Adaptativa e de Demonstração de tecnologias inovadoras; desenvolver pesquisa adaptativa nas áreas de melhoramento genético, solos/nutrição/plantio direto e manejo integrado de pragas; reforçar a capacitação de pesquisadores, técnicos e agricultores líderes dos países do C-4 em novas tecnologias de produção de algodão; e preparar e disseminar materiais de divulgação sobre os conhecimentos validados para a melhoria da produção do algodão nos países do C-4. Foi financiado pela ABC/MRE e teve como orçamento inicial US\$ 4,7 milhões para os três anos estimados de sua duração, além de contar com recursos do Instituto Brasileiro do Algodão (IBA) e com as horas técnicas dos profissionais da Embrapa (analistas e pesquisadores), totalizando aproximadamente US $\$ 5,21$ milhões. O sucesso do projeto garantiu uma segunda fase, iniciada em 2014, chamada Cotton 4 + Togo, cujo foco é o reforço tecnológico e a difusão de boas práticas agrícolas para o algodão nos países do C-4 e no Togo. Tem ainda o Projeto Cotton Mamo, que será lançado em breve e realizado em Moçambique e no Malaui. Também voltado para o aumento da competitividade do setor algodoeiro, está em fase de negociação o Projeto Regional Fortalecimento do setor algodoeiro na Bacia do Lago Vitória, envolvendo a Tanzânia, o Burundi e o Quênia.

Recentemente, foi iniciada a execução do Projeto Fortalecimento da Capacidade de Pesquisa e Inovação dos Institutos de Investigação Agronômica e Veterinária de Angola para apoio e fortalecimento institucional da pesquisa agrícola 
no país, financiado pelo próprio governo de Angola, com recursos até U\$2,1 milhões.

Vários outros projetos, de menor porte, ocorrem em parceria com as unidades descentralizadas, tais como a melhoria na suinocultura da Etiópia por meio da caracterização genética e socioeconômica e do desenvolvimento de um sistema de produção, por iniciativa da Embrapa Suínos e Aves, de Concórdia, Santa Catarina; e a fenotipagem, genotipagem e análise da diversidade genética e estrutura de uma coleção da Etiópia de Coffea arabica, pela Embrapa Café.

O ciclo de gestão dos projetos estruturantes envolve quatro etapas: (1) a preparação, (2) o planejamento e a programação, (3) a implementação e (4) a avaliação. A preparação e o planejamento requerem um longo tempo de envolvimento dos técnicos, e geralmente envolvem visitas técnicas aos países onde serão desenvolvidas as atividades do projeto. Ao longo da fase de implementação, os planos anuais de trabalho são revistos e ajustados. O investimento na etapa de avaliação dos projetos é relativamente recente na Embrapa. O projeto Cotton 4, finalizado no ano passado, foi um dos primeiros projetos que contou com uma equipe de avaliadores de diferentes instituições.

Além dos projetos estruturantes e daqueles de menor porte ou curta duração, a publicação, a Embrapa promove as Plataformas de Inovação Agropecuária (ÁfricaBrasil e América Latina e Caribe-Brasil). Essas são iniciativas internacionais, apoiadas por diversos parceiros, com o objetivo de promover a inovação agrícola e aumentar a produtividade de forma sustentável. Profissionais da Embrapa e de outras instituições brasileiras desenvolvem projetos de pesquisa conjunta com profissionais de instituições da África, América Latina e do Caribe, em prol do desenvolvimento da agricultura nos países parceiros, principalmente em benefício dos pequenos produtores (EMBRAPA, 2014e).

As plataformas têm a finalidade de financiar projetos voltados para 0 desenvolvimento e a inovação da agricultura, além de fortalecer as relações entre as instituições dos países envolvidos. Ao longo dos quatro anos de existência, desde sua criação em 2010, foram financiados 42 projetos em 13 países da África e oito em seis países da América Latina e do Caribe. Esses projetos envolvem parcerias com, pelo menos, 22 das 47 Unidades Descentralizadas da Embrapa. Dos projetos executados nos países africanos, a grande maioria foi realizada em países de língua inglesa: 19\% em Uganda, 17\% no Quênia, 17\% na Etiópia e 10\% no Gana. Dentre 
as principais unidades participantes, a Embrapa Recursos Genéticos e Biotecnologia e a Embrapa Meio-Norte lideram em número de projetos, cada uma com $14 \%$ do total.

A agenda de capacitação da Embrapa, focada em compartilhamento e transferência de conhecimentos e tecnologias (EMBRAPA ESTUDOS E CAPACITAÇÃO, 2014) era coordenada e executada pelo Centro de Estudos e Capacitação em Agricultura Tropical (Cecat), criado em dezembro de 2009 e extinto em 2014, em articulação com as UDs. Conforme orientado no Boletim de Comunicações Administrativas - BCA no 31, de 1 de julho de 2014, que informou a Resolução do Conselho de Administração - RCA, no 141, de 25 de junho de 2014, as ações de capacitação internacional foram redirecionadas para o Departamento de Transferência de Tecnologia - DTT.

A partir da exposição dos modelos adotados pelo Brasil e da troca de experiências na área, os programas e projetos mais relevantes realizados pelo extinto Cecat foram: 1) o Programa Diálogo Brasil-África sobre Segurança Alimentar, Combate à Fome e Desenvolvimento Rural, iniciado em 2010, em parceria com a ABC/MRE, envolvendo 45 países africanos; 2) o Programa de Treinamento para Terceiros Países (Third Country Training Program, TCTP), financiado pela ABC em parceria com a JICA; cujos cursos tinham foco em produção de hortaliças e caju; 3) - Programa Cooperação Técnica Brasileira: Agricultura, Segurança Alimentar e Políticas Públicas; 4) o Projeto de Apoio aos Programas de Segurança Alimentar e Nutricional de Moçambique (PSAL), iniciado em 2012, com atividades nas áreas socioeconômica, de sistemas de produção, pós-colheita e processamento, além de capacitação e transferência de tecnologia, tudo isso voltado à cadeia de horticultura; entre outros.

De um modo geral, seja por meio dos projetos estruturantes ou de menor porte, do Marketplace ou das capacitações internacionais, a Embrapa tem atuado, de forma sistemática, para o desenvolvimento da agricultura no Brasil e no exterior.

\subsection{O Caso do Projeto Prosavana}

Neste subcapítulo será apresentado o estudo de caso do projeto estruturante ProSavana - PI, serão descritos alguns dos desafios enfrentados na sua implementação, as limitações da Empresa, os avanços reconhecidos e as potenciais 
ameaças à sua continuidade, com foco na execução das atividades em Moçambique.

\subsubsection{O Programa ProSavana - JBM e o milagre do cerrado}

Moçambique tem enfrentado enormes restrições no setor agrícola, principalmente no que se refere à produção de alimentos, segurança alimentar e produtividade rural. Segundo Branco et. al (2010), o desenvolvimento rural é a alternativa para enfrentar suas limitações. No entanto, para atingir 0 desenvolvimento rural, a industrialização, como um processo de transformação e articulação da base social, econômica, logística e tecnológica da produção do comércio, deve fazer parte de uma estratégia nacional de desenvolvimento (IESE, 2010). Dentro dessa perspectiva, um dos maiores desafios de Moçambique é transformar a região de Nacala em um polo de desenvolvimento agropecuário para atender a demanda crescente por alimentos da sua população e gerar divisas com a exportação desses produtos (EMBRAPA MONITORAMENTO POR SATÉLITE, 2010). "A estratégia econômica e social da nação moçambicana baseia-se no setor primário e na disponibilidade dos fatores terra e trabalho" (EMBRAPA MONITORAMENTO POR SATÉLITE, 2010, p. 13). Na expectativa que a agricultura se tornasse um dos principais motores do desenvolvimento desta região, surgiu o ProSavana.

O projeto da Embrapa, conhecido como ProSavana, faz parte de um programa mais amplo, o ProSavana - Japão BM, lançado em 2009. O ProSavana - JBM é um programa de cooperação triangular entre Governos de Moçambique, representado pelo Ministério da Agricultura; do Brasil, representado pela ABC e Embrapa, e do Japão, representado pela JICA. O foco da cooperação é o desenvolvimento agrícola e rural das savanas tropicais, em Moçambique, especificamente no Corredor de Nacala. De acordo com o relatório da Federação de Órgãos para Assistência Social e Educacional $(F A S E)^{20}$, esta "é atualmente a maior iniciativa de cooperação da história do Programa de Parceria Japão-Brasil (PPJB), lançado em 2000" (SCHLESINGER, 2013, p. 17).

O programa ProSavana - Japão Brasil Moçambique (JBM) é inspirado na experiência do Programa de Cooperação Nipo-brasileira para o Desenvolvimento

\footnotetext{
${ }^{20}$ FASE - organização não governamental, sem fins lucrativos, sediada no Brasil.
} 
dos Cerrados (Prodecer), firmado entre o governo brasileiro e a JICA, e desenvolvido por mais de vinte anos no Brasil, a partir de 1978. O Prodecer foi um marco da cooperação internacional entre Brasil e Japão, visando à produção de commodities, com alta demanda internacional no cerrado brasileiro (RODRIGUES; VASCONCELOS; BARBIERO, 2009). Por meio do Prodecer, buscou-se implantar um modelo agrícola eficiente, com empreendimentos de médio porte e infraestrutura para promover o crescimento econômico da região.

O cerrado era considerado uma área imprópria para agricultura. A iniciativa do Prodecer culminou com a transformação dessa região do país em um grande celeiro mundial. Em 2008, "a região dos Cerrados, em virtude de um conjunto de tecnologias especificamente desenvolvidas para este bioma, tornou-se responsável por 67,8 milhões de toneladas de alimentos, 48,5\% da produção brasileira" (ABC, 2011 , p. 24). Devido ao aumento da produção agrícola com esta e outras iniciativas, que desenvolveram uma região anteriormente pobre, o Brasil deixou de ser um país importador. Tornou-se o principal exportador de alimentos e maior produtor mundial de uma grande variedade de produtos agrícolas. Desse modo, o Brasil ganhou competitividade no cenário internacional e a Embrapa foi reconhecida por sua atuação.

O programa ProSavana foi elaborado sob a expectativa de replicar essa história de sucesso do Brasil em Moçambique, mais especificamente no corredor de Nacala, "região com o maior potencial para o desenvolvimento agrícola de toda a África Austral” (EMBRAPA MONITORAMENTO POR SATÉLITE, 2010, p. 45). Tendo em vista que o Corredor de Nacala assemelha-se às condições agroclimáticas encontradas no cerrado brasileiro, a partir do conhecimento e das técnicas e tecnologias agrícolas da Embrapa, esperava-se promover o desenvolvimento agrícola das savanas de Moçambique. Conforme argumentam Lídia Cabral et al.,

\footnotetext{
O ProSavana está empacotado em uma narrativa convincente de sucesso. Em menos de três décadas o Brasil tornou-se um grande exportador de alimentos e o maior produtor mundial de uma variedade de produtos agrícolas, incluindo a soja do cerrado. A inovação tecnológica e o trabalho da Embrapa em particular, tiveram um papel fundamental no 'milagre do cerrado' (CABRAL; et al., 2012, p. 18, tradução nossa) ${ }^{21}$.
}

\footnotetext{
${ }^{21}$ ProSavana is packaged in a compelling narrative of success. In less than three decades Brazil turned itself into a major food exporter and the world's largest producer of a variety of agricultural commodities, including soybeans from the cerrado. Technological innovation, and the work of Embrapa in particular, is argued to have played a key role in the 'miracle of the cerrado' (CABRAL, et al. 2012, p. 18).
} 
Uma das preocupações mais recorrentes entre os que criticam o ProSavana é que, além dos acertos, se repitam os erros do Prodecer que geraram impactos negativos para o Cerrado, segundo maior bioma brasileiro em termos de biodiversidade, provocando desmatamento, morte e migração de espécies (ESTARQUE, 2013). O Prodecer foi especialmente criticado por causar problemas de ordem ambiental e social, tais como a destruição do bioma e a exploração de trabalhadores rurais. A esse respeito, Fingermann acredita que os países aprendem com os erros:

Assumir que o ProSavana vai replicar os erros que ocorreram no PRODECER é, no mínimo, negar a capacidade de aprendizado dos países. Hoje, são reconhecidos os problemas oriundos deste último Programa, sem isso ser escondido pelos governos brasileiro e japonês (FINGERMANN, 2013, p. 21).

Nogueira et al. (2013), da mesma forma, acreditam que o ProSavana - por ser um projeto de desenvolvimento de 20 anos - representa uma oportunidade de desencadear mudanças estruturais no sistema socioeconômico em 19 distritos das províncias de Nampula, Niassa e Zambézia, onde vivem 4,3 milhões de pessoas.

Enquanto Fingermann (2013) e Nogueira et al. (2013) enxergam oportunidades no ProSavana, a pesquisadora japonesa Sayaka Funada Classen, professora da Universidade de Estudos Estrangeiros de Tóquio, percebe um jogo de interesses tanto do Brasil como do Japão. Ela afirma que o objetivo do Japão com projetos de cooperação na África, como o ProSavana, é garantir a oferta de alimentos para o consumo dos japoneses. Segundo ela, tanto o Prodecer quanto o Prosavana foram idealizados com vistas a minimizar o impacto das crises mundiais de alimentos de 1973 e de 2008, e para promover a imagem japonesa no exterior (CLASSEN, 2013).

Assim como Classen (2013), Nogueira et al. (2013) indicaram a preocupação dos japoneses em promover o aumento da produção de alimentos do mundo. Porém, a versão apontada pelo primeiro autor, sinalizando o interesse com a geração de produtos para o consumo dos próprios japoneses é contradita:

Numa perspectiva de interesse estratégico japonês, estes investimentos, como o próprio ProSavana, visam aumentar a produção mundial de alimentos e, assim, estabilizar os preços dos alimentos globalmente - um entendimento compartilhado por diferentes membros da equipe de 
ProSAVANA em reuniões públicas e privadas (NOGUEIRA; OLINAHO, 2013, p. 5, tradução nossa). ${ }^{22}$

Conforme Nogueira e Olinaho (2013), "o ProSavana tornou-se o programa brasileiro mais contestado pela sociedade civil moçambicana"(p. 6). Nogueira e Olinaho (2013), inclusive, percebem que algumas críticas são legítimas:

Problemas relacionados à gestão altamente opaca e incoerências na escassa informação que foi compartilhada com o público, combinado com os atrasos no lançamento de parte do programa "social" (serviços de extensão para os camponeses), induziram uma onda de críticas e medos relacionados à grilagem de terra, reassentamentos, segurança alimentar reduzida e crescente desigualdade. Por que isto? A cooperação brasileira não deveria ser saudada pelos países beneficiários uma vez que abraça princípios como ser desatrelada de interesses comerciais, ter abordagem orientada para a demanda e estrutura participativa? O ProSavana, de fato, não segue alguns dos princípios mais salientes da CSS, tornando as críticas compreensíveis e legítimas (NOGUEIRA; OLINAHO, 2013, p. 6, tradução nossa) ${ }^{23 .}$

Assim como Nogueira e Olinaho (2013), Classen (2013) afirma que o programa não foi concebido em conjunto com as comunidades locais e acentua interesses político-econômicos:

Desde o seu início, o programa ProSAVANA não foi concebido em conjunto com os habitantes da região, nem houve interesse em ir ao encontro das necessidades locais. Ao contrário, o projeto foi concebido como uma maneira do Japão e Brasil trabalharem juntos para alcançar uma reforma da ONU, participarem em novas estruturas políticas e económicas globais, como BRICS e o G20, e promoverem conjuntamente a extração e produção de bens (CLASSEN, 2013, p. 3).

No discurso sobre cooperação entre países em desenvolvimento, a busca por soluções compartilhadas é estimulada. Entretanto, nem sempre a prática reproduz essa abordagem, prevalecendo algum tipo de verticalidade na inter-relação de prestador e recipiendário (PUENTE, 2010). Ainda é possível que a horizontalidade não ocorra adequadamente na esfera interna, embora possa prevalecer nas relações entre governos.

\footnotetext{
${ }^{22}$ From a Japanese strategic interest perspective, these investments, like ProSAVANA itself, aim at increasing world food production and thus stabilizing global food prices - an understanding shared by different ProSAVANA staff members in both private and public meetings (NOGUEIRA; OLINAHO, 2013, p. 5).

${ }^{23}$ The highly opaque management and incoherencies in the scarce information that has been shared with the public, combined with delays in launching the program's "social part" (extension services for peasants), have induced a wave of criticism and fear related to land grabbing, resettlements, reduced food security and growing inequality. Why is this? Should the Brazilian cooperation not be welcomed by recipient countries once it embraces principles such as no links to commercial interests, a demand-driven approach, and a participatory framework? ProSAVANA does not follow some of the most salient principles of SSDC, rendering the criticisms both understandable and legitimate (NOGUEIRA e OLINAHO, 2013, p. 6)
} 
Além da dificuldade em tornar o discurso uma prática real nas ações de cooperação internacional, é necessário compreender o contexto histórico, econômico, social, ambiental e político no qual um programa ou projeto foi estabelecido. No início dos anos 70, o Brasil tinha um desafio similar ao moçambicano. No entanto, para enfrentá-lo, investiu em pesquisa e desenvolvimento do bioma cerrado, para adequá-lo à produção agrícola e preserválo através do desenvolvimento sustentado dessas áreas (EMBRAPA MONITORAMENTO POR SATÉLITE, 2010). Por trás do milagre do cerrado, o Brasil contava com terra arável, água em abundância e a participação dos pesquisadores da Embrapa, cujos estudos envolviam melhoramento do solo e técnicas de adaptação de culturas a zonas tropicais. "A situação socioeconômica da região do Cerrado brasileiro é significativamente distinta daquela existente na Savana Africana" (SCHLESINGER, 2013, p. 16).

Apesar do potencial de clima e solo, Moçambique tem carência de recursos humanos, materiais e tecnológicos. Enquanto, no Brasil, os pesquisadores da Embrapa já promoviam inovação na década de 1970, Moçambique não tem investimentos próprios em Ciência e Tecnologia. O país africano conta com poucas universidades públicas, entre elas, a Universidade Eduardo Mondlane (UEM) e a Universidade Pedagógica (UP), em Maputo, e a Universidade Lúrio, em Nampula. Os apontamentos dos técnicos no formulário "Documento Orientador para a missão de levantamento de demandas de capacitação", durante visita a Moçambique, registraram forte dependência externa, pouca capacidade real de definição de políticas, somente duas escolas técnicas agrícolas, além de problemas de transporte e de infraestrutura.

A partir do exposto, seria, realmente, possível transferir o pacote tecnológico da Embrapa e o "milagre do Cerrado" para as savanas de Moçambique? Cabral et al. (2012) acreditam que atingir isso é uma miragem:

Poderão os fatores de natureza política, social, institucional e humana que moldaram a história do cerrado serem incorporados aos conhecimentos tecnológicos do ProSavana? Provavelmente não, dado que esses fatores dizem respeito a um momento temporal particular. A governança, as instituições e a política em Moçambique são todas elas muito diferentes do contexto que hospedou a transformação do cerrado. E, de toda forma, as marcas sociais e ambientais dessa transformação continuam a ser tema de debate. Olhando além do horizonte da savana moçambicana, o milagre do 
cerrado parece cada vez mais uma miragem (CABRAL, et al., 2012, p. 18, tradução nossa) $)^{24}$.

Moçambique, no decurso dos anos 1980, realizou importantes reformas políticas a fim de reduzir a degradação das condições sociais e macroeconômicas gerada pela deterioração do modelo de Estado socialista vigente. No entanto, ainda é importante promover um maior investimento em práticas de gestão pública voltadas à responsabilização e à transparência. Delimitar políticas com objetivos claros, buscar a satisfação dos interesses coletivos das comunidades, estimular a cooperação entre atores públicos e privados e promover a gestão de políticas públicas mais inclusivas e interativas podem gerar melhor governança no setor público (SIMIONE, 2014). Atualmente, Moçambique vivencia um crescimento macroeconômico alavancado por investimentos estrangeiros nos setores de mineração e energia, relacionados com a produção de carvão, alumínio e gás. No entanto, tais investimentos criam poucos empregos e, em função da prática de privilégios e isenções fiscais, não têm estabelecido relações fiscais relevantes com 0 orçamento público (MORAIS, 2014).

Para fortalecer as instituições de pesquisa, é preciso, assim como foi realizado na Embrapa, nos anos 1970, que o IIAM invista na formação profissional dos técnicos, não apenas nos treinamentos profissionalizantes, mas também em avanços acadêmicos. Promover uma cultura de inovação e estímulo ao desenvolvimento de competências exige tempo e investimento financeiro. A fim de garantir uma boa governança pública e institucional, na prática, é preciso que Moçambique solucione limitações de natureza estrutural e funcional (SIMIONE, 2014).

\subsubsection{Interpretações e especulações em torno dos investimentos estrangeiros}

Existe preocupação em torno do grande número de investimentos estrangeiros em infraestrutura no corredor de Nacala. A falta de transparência do governo de

\footnotetext{
${ }^{24}$ Can the political, social, institutional and human drivers of the cerrado story be packaged along with the technological expertise of ProSavana? Probably not, as these drivers were quite specific to Brazil in a particular moment in time. Mozambique's agricultural governance, institutions and politics are all quite different to the context that hosted the cerrado transformation. And in any case, the social and environmental record of such transformation remains a matter of dispute. Looking out from the Mozambican savannah, the miracle of the cerrado looks increasingly like a mirage (CABRAL, et al., 2012, p. 18).
} 
Moçambique e a limitada participação da sociedade na tomada de decisões geraram desconfiança nas organizações não governamentais quanto ao reassentamento dos produtores locais e à gestão de possíveis conflitos em torno da propriedade e uso da terra (MORAIS, 2014).

Cabral et al. sinalizam que a União Nacional de Camponeses (UNAC) tem condenado a falta de transparência dos três governos envolvidos, bem como sua falta de diálogo com a sociedade civil e agricultores locais:

A União Nacional de Camponeses (UNAC), por exemplo, tem condenado,
antes de tudo, a falta de transparência por parte dos governos de
Moçambique, Brasil e Japão no processo ProSavana e a falta de
envolvimento das organizações da sociedade civil e dos agricultores em
particular. Também levantou preocupações sobre grilagem de terras pelos
agronegociantes brasileiros e sobre a esperada distribuição desigual dos
benefícios do modelo idealizado para a transformação da savana, visto
como tendencioso para a produção em grande escala de cultivos comerciais
para a exportação (CABRAL, et al., 2012, p.17, tradução nossa) ${ }^{25}$.

A falta de transparência assinalada tanto por Classen (2013) como por Cabral et al. (2012) e Morais (2014) resulta em interpretações, especulações e investigações sobre as reais motivações para a CTPD entre os três países envolvidos.

Segundo Fingerman (2013), pode, de fato, haver empresas estrangeiras interessadas em investir no Corredor de Nacala, motivadas pela existência de um Programa de longo prazo. Schlesinger (2013) levanta em sua análise os ganhos de empresas brasileiras e multinacionais, por meio da abertura de mercado:

É crescente a presença de empresas brasileiras, tanto as de capital privado
quanto as estatais naquele continente. Através do Banco Nacional de
Desenvolvimento Econômico e Social (BNDES), o governo brasileiro
financia também uma série de obras de engenharia que facilitam a
celebração de contratos de obras das mais diversas modalidades. Ao
mesmo tempo, fundos de investimento buscam captar recursos financeiros
para viabilizar os crescentes investimentos do Brasil na África
(SCHLESINGER, 2013, p. 11, tradução nossa).

A corporação brasileira Vale, por exemplo, reabilitará $912 \mathrm{~km}$ de estradas ferroviárias que ligam a usina de carvão, por ela operada, na província de Tete até o

\footnotetext{
${ }^{25}$ The Mozambican National Farmers Union (UNAC), for instance, has condemned first of all the lack of transparency on the part of the governments of Mozambique, Brazil and Japan in the ProSavana process and the lack of involvement of civil society organizations and farmers in particular. It also has voiced concerns about land grabbing by large Brazilian agribusinesses, and the expected unequal distribution of benefits from the envisaged model of savannah transformation, seen as biased towards largescale production of cash crops for exports (CABRAL, et al., 2012, p.17).
} 
porto de Nacala, onde a mineradora escoará o carvão extraído (MORAIS, 2014). Outras empresas privadas brasileiras estão presentes em Moçambique, envolvidas em megaprojetos: a Odebrecht com a construção do Aeroporto de Nacala; a Andrade Gutierrez com a construção de uma barragem na província de Maputo; e a Camargo Corrêa, com a construção da mina de carvão de Moatize.

Com relação à afirmação de Schlesinger (2013), pode-se acrescentar a ligação do ProSAVANA com o Fundo Nacala, um fundo de investimento cujo objetivo seria levantar US\$ 2 bilhões em 10 anos para financiar investidores no corredor. Desde sua concepção, esse fundo apoia o desenvolvimento agrícola em larga escala, e por isso tem suscitado várias dúvidas sobre a suposta falta de interesses comerciais por parte do Brasil. A esse respeito, cabe destacar que o fundo selecionou dez fazendeiros brasileiros para atuação conjunta com produtores moçambicanos de médio porte na produção em larga escala (NOGUEIRA, 2014). Segundo Schlesinger (2013),

Neste sentido, a FGV Projetos, da Fundação Getúlio Vargas, pretende
captar recursos da ordem de US $\$ 1$ bilhão para o desenvolvimento dos
projetos agrícolas. O fundo é coordenado pelo DWS Investments, gestor
pertencente ao Deutsche Bank, da Alemanha. Além disso, em junho de
2012 , o BTG Pactual, maior banco de investimento no Brasil, também
anunciou a intenção de levantar US $\$ 1$ bilhão e criar um fundo de
investimentos do mundo para a África, voltado para áreas como
infraestrutura, energia e agricultura. No caso de Moçambique, foi lançado
em julho de 2012 um fundo destinado a captar US 2 bilhões no setor do
agronegócio (SCHLESINGER, 2013, p. 11).

Nogueira e Olinaho (2013) também afirmam que o ProSavana está relacionado com uma grande rede de investimentos:

Sendo o corpo agrícola do plano de desenvolvimento do extenso Corredor de Nacala, o ProSavana está localizado dentro de uma grande rede de investimentos públicos e privados que estão ocorrendo na região. Se todos estes investimentos se materializarem, vão representar uma das mais impressionantes e concatenadas iniciativas de infraestruturas de desenvolvimento nesta parte da África. Eles incluem investimentos da mineradora brasileira Vale, que oficialmente não estão relacionados com 0 programa, mas ainda estão altamente imbricados em termos práticos. Além disso, uma soma de outros projetos de infraestrutura está sendo financiada pelo governo japonês, tais como a modernização e expansão do porto de Nacala e a modernização das estradas principais ao longo do Corredor, incluindo as rotas de Nampula-Cuamba, Cuamba-Mandimba e MandimbaLichinga, totalizando mais de 650 km (NOGUEIRA; OLINAHO, 2013, p. 5, tradução nossa). ${ }^{26}$

\footnotetext{
${ }^{26}$ As the agricultural body of the broader Nacala corridor development plan, ProSAVANA is located within a large web of foreign private and public investments that are taking place in the region. If all these investments materialize, they will represent one of the most impressive and concatenated infrastructure development
} 
A relação investimentos públicos e privados pode dar margem para interpretações díspares, pois enquanto alguns podem interpretá-los como tendenciosos e oportunistas, outros podem compreender que tais iniciativas gerarão empregos, aumento da renda, crescimento econômico para Moçambique. Frederico Dimas Paiva (2013) citou que:

Advogar a ideia de que o Programa apoia uma invasão de agricultores
brasileiros, que, por sua vez, ocuparão terras dos agricultores
moçambicanos, é, digamos, desinformar. Não há crédito nem qualquer tipo
de apoio a esse suposto processo o que, pessoalmente, vejo como
equívoco estratégico brasileiro (PAIVA, 2013, p. 15).

Assim como Paiva (2013), Fingermann (2013) tem uma percepção positiva sobre o ProSavana e acredita que demonizá-lo não é o caminho para a segurança alimentar, tão necessária em Moçambique.

A estratégia de demonizar o ProSavana pelo fato dele procurar estabelecer um elo entre a agricultura comercial e a agricultura familiar não leva a lugar nenhum. $O$ Programa é uma demanda do governo de Moçambique, que entende que é necessário diversificar a produção interna para conseguir atender as demandas locais e garantir a segurança alimentar da população (FINGERMANN, 2013, p. 22).

Vale ressaltar que Paiva e Fingermann publicaram suas opiniões na Revista da FGV Agroanalysis, e que a FGV Projetos é alvo de várias críticas por ter sido responsável pelo desenvolvimento do Plano Diretor e, ao mesmo tempo, pela gestão do Fundo Nacala. Paiva é, inclusive, consultor da FGV. Acima desses eventuais interesses, há outros de escala muito maior que não envolvem cooperação, mas competição entre grandes empresas. Além das empresas relacionadas ao ramo de construção, mineração, engenharia e energia, tais como as brasileiras Vale, Odebrecht, Camargo Corrêa, Andrade Gutierrez e Eletrobrás, instituições internacionais também estão presentes em Moçambique, tais como a Fundação Bill e Melinda Gates, Monsanto, Cargill, Bayer, entre outras. A disputa por espaços comerciais, em Moçambique, aumenta entre elas e novas empresas que percebendo os avanços e ganhos empresariais adentram o país.

initiatives in this part of Africa. They include investments from the Brazilian mining company Vale, which are not officially related to the program but are still highly imbricated in practical terms. In addition, a number of other infrastructure projects are being financed by the Japanese government, such as modernization and expansion of the Nacala Port and upgrading of the main roads along the corridor, including the routes Nampula-Cuamba, Cuamba-Mandimba and Mandimba-Lichinga, totaling more than 650 km (NOGUEIRA; OLINAHO, 2013, p. 5). 
4.3.4 O Projeto ProSavana - Pl: a participação da Embrapa em um cenário conflituoso

O Programa ProSavana Japão Brasil Moçambique (JBM) é composto por três projetos específicos, cada um com uma duração diferente, a saber: o Projeto de Investigação (PI) - Pesquisa, 5 anos (2011-2015;) o Plano Diretor (PD) - 15 anos e o Projeto de Extensão e Modelos - 20 anos. Apenas o ProSavana - PI tem sido conduzido pela Embrapa.

O ProSavana PI, cujo nome completo é "Projeto de Melhoria da Capacidade de Pesquisa e de Transferência de Tecnologia para o Desenvolvimento da Agricultura no Corredor de Nacala", é um projeto trilateral que conta com recursos dos governos do Brasil, através da Agência Brasileira de Cooperação ( $A B C)$, do Japão, via Agência Japonesa de Cooperação Internacional (JICA) e de Moçambique, representado pelo Ministério da Agricultura de Moçambique (MINAG). Foi estabelecido a partir do Memorando de Entendimento entre as três partes, firmado em setembro de 2009, iniciado em 2011 e com término previsto para 2016. Conta com o apoio técnico do Japan International Research Center for Agricultural Sciences (JICARS), da Embrapa e do Instituto de Investigação Agrária de Moçambique (IIAM).

O ProSavana PI objetiva a validação e transferência da tecnologia agrária adequada na Região do Corredor de Nacala. Faz parte de um projeto mais amplo, o Programa Embrapa-Moçambique, o qual tem como objetivo o fortalecimento da capacidade do sistema de inovação tecnológica em áreas estratégicas para o desenvolvimento agrícola de Moçambique. Além disso, visa aumentar a competitividade do setor, tanto em matéria de segurança alimentar como na geração de excedentes exportáveis (EMBRAPA MONITORAMENTO POR SATÉLITE, 2010). Além do ProSavana-PI, compõe o Programa Embrapa Moçambique o Projeto de Apoio Técnico à Plataforma de Inovação Agrária e Inovação Tecnológica para Moçambique (PIAT) e o Projeto de Apoio Técnico aos Programas de Nutrição e Segurança Alimentar (Proalimentos), ambos em parceria com a USAID (Embrapa Monitoramento por Satélite, 2010), apresentados na seção anterior.

De acordo com os Planos Técnicos (2011) do ProSavana-PI, o projeto foi estruturado, levando em consideração seis componentes: (1) Fortalecimento da Infraestrutura física dos Centros Zonais e Capacitação e Treinamento no Brasil e em Moçambique; (2) Avaliação de Impactos Socioambientais e das Condições 
Socioeconômicas; (3) Recursos Naturais: Avaliação e Zoneamento Agroecológico; (4) Sistemas de Produção para Agricultura e Pecuária; (5) Sistemas de Produção para Agricultura Familiar; (6) Coordenação Geral do ProSavana no Brasil e em Moçambique (EMBRAPA, 2011b).

Em termos do componente 1, foi previsto o estudo para a elaboração e negociação de projetos de arquitetura e engenharia, construção e aparelhamento dos Centros Integrados de Investigação Agrária e Transferência de Tecnologia (CIIAT) de Nampula e Lichinga. Os ClIATs deveriam ser equipados com máquinas e instrumentos modernos e unidades de beneficiamento de sementes genéticas e básicas (EMBRAPA, 2011b). Além dos laboratórios, no âmbito do componente 1 seriam desenvolvidos recursos humanos com capacidades em pesquisa para "conduzir e promover ações de construção coletiva de conhecimentos voltados para o desenvolvimento, adaptação, difusão, adoção e avaliação de impacto de tecnologias" (EMBRAPA, 2011b, p. 14).

$\mathrm{Na}$ Descrição do Projeto afirma-se, que "o desenvolvimento de capacidades não pode se limitar à transferência de tecnologia, [...] o foco dos programas será o fortalecimento das competências locais" (EMBRAPA, 2011b, p. 17).

Com base no documento interno Planos Técnicos (2011), o componente 2 visava construir uma base de conhecimentos sobre as condições socioambientais prevalecentes nas Províncias de Niassa e Nampula, e desenvolver uma metodologia informatizada de avaliação ex-ante e ex-post dos impactos socioambientais decorrentes de intervenções.

O escopo do componente 3 era desenvolver ações relativas aos estudos de mapeamento de solos e organização de dados climáticos existentes visando a elaboração de um zoneamento agroecológico para dar suporte ao desenvolvimento da agricultura em bases sustentáveis na área prioritária do Corredor de Nacala.

O componente 4 visava elaborar e executar planos e projetos de pesquisa e experimentação para o desenvolvimento e difusão de sistemas de produção agrícolas orientados para a agricultura comercial e agroexportadora do Corredor de Nacala. Além disso, visava contribuir para o desenvolvimento científico e tecnológico em produção animal. Para isso, campos agrostológicos seriam estruturados de forma a observar as principais forrageiras tropicais desenvolvidas no Brasil na área de atuação do IIAM. A intenção era contribuir para o desenvolvimento sustentável da cadeia produtiva da pecuária de grande e médio porte, inclusive a avicultura. 
O componente 5 tinha por finalidade a disseminação das novas tecnologias e sistemas de produção validados a partir das ações previstas no componente $4 \mathrm{e}$ recomendados para emprego no âmbito da agricultura familiar. Atuaria com base na organização de polos de irradiação de tecnologias e estabelecimento de campos de validação em comunidades de agricultura familiar, localizadas em áreas próximas das estações experimentais do IIAM em Nampula e Niassa. A metodologia prevista promoveria processos de pesquisa participativos, descentralizados e com enfoque na agrobiodiversidade e na agroecologia, levando em conta critérios de sustentabilidade ambiental.

A finalidade do componente 6 era organizar e financiar a instalação e o funcionamento da Coordenação Geral do ProSavana - TEC com a incumbência de desenvolver as atividades de responsabilidade da parte brasileira nas Províncias de Niassa e Nampula, em Moçambique.

Na prática, somente o componente 4 "Sistemas de Produção para Agricultura e Pecuária" avançou de forma mais efetiva. Após o início do Projeto ProSavana_PI, um cenário de críticas das mais variadas colocou em risco tanto a atuação da Embrapa como de outros atores envolvidos no Projeto. A Embrapa, tendo em vista que o foco da sua atuação está centrado em ações de pesquisa, não está envolvida com disputas e interesses relacionados à política externa do Brasil, Japão e Moçambique. Tampouco faz parte do jogo de interesses comerciais das multinacionais brasileiras e estrangeiras no corredor de Nacala. Tais críticas não são direcionadas diretamente à Empresa, mas ao Programa, de modo geral, e ao cenário decorrente de sua implementação. Não obstante, atualmente, o Projeto de Investigação segue em ritmo lento e sua continuidade está em estudo, inclusive tendo em vista sua possível suspensão.

De todo modo, a respeito do Projeto ProSavana - PI, cabe destacar que a Embrapa não efetivou plenamente cinco dos seis componentes. O planejamento inicial não tem sido cumprido, sendo que apenas o componente 4 - "Sistemas de Produção para Agricultura e Pecuária" avançou de forma mais efetiva. Ainda assim, por falta de recursos, esse componente não obteve o sucesso pretendido. A produção ficou limitada em razão da realização parcial do componente 1 "Fortalecimento da Infraestrutura física dos Centros Zonais e Capacitação e Treinamento no Brasil e em Moçambique". 
Conforme dito anteriormente, em Moçambique existe a preocupação de que o ProSavana promova o desenvolvimento agrícola em larga escala, ao invés do rural, através de investimento direto. De fato, o projeto promove um modelo de monoculturas e latifúndios, para atender as demandas do mercado externo. Desse modo prejudica a agricultura familiar e de pequena escala do próprio país (CLASSEN, 2013). Assim sendo, o fato da Embrapa não ter conduzido suas atividades conforme planejado no componente 5, referente a Sistemas de Produção para Agricultura Familiar, pode ter dado a impressão que a Empresa favoreceu os latifundiários.

Segundo a Embrapa, na região do Corredor de Nacala foi realizado um estudo minucioso de aptidão climática por cultura, considerando o balanço hídrico para três cenários pluviométricos: anos secos, anos normais (regulares), e anos úmidos. Houve, também, a identificação de impactos ambientais por meio das metodologias Ambitec-Agro e Ambitec-Social (EMBRAPA, 2011b). A tentativa, conforme exposto nos documentos do Projeto, foi de construir uma estratégia que levasse em conta os diversos elementos que integram o cenário rural de Moçambique, tomando a produção agrícola como uma oportunidade para avançar na redução das desigualdades sociais.

De acordo com uma publicação da Embrapa Monitoramento por Satélite, havia preocupação, inclusive, com as diferenças socioeconômicas entre Brasil e Moçambique:

[...] esse trabalho não é de mera transferência da experiência do cerrado brasileiro uma vez que há diferenças socioeconômicas significativas, [...] mas de aproveitamento do aprendizado e das técnicas desenvolvidas em outras iniciativas da empresa, respeitando as peculiaridades de Moçambique (EMBRAPA MONITORAMENTO POR SATÉLITE, 2010).

De toda forma, apesar das boas intenções, o Projeto não conseguiu atingir suas metas, frustrando não somente aos moçambicanos, mas também aos próprios técnicos da Embrapa, conforme descrito no próximo subcapítulo. Sucessivos cortes de recursos do Governo Dilma Rousseff para o MRE (também conhecido e aqui referido como "Itamaraty") provocaram a redução das despesas da ABC para várias atividades, causando adiamento de missões, cancelamento de cursos de treinamento e suspensão de alguns componentes do Projeto.

A parceira JICA, que não sofreu cortes de recursos, de modo geral, deu continuidade aos seus planos iniciais e seus técnicos puderam trabalhar contando 
com uma boa infraestrutura. Ainda assim, as ações conjuntas foram prejudicadas. $O$ projeto, que foi desenhado e estabelecido contando com contrapartidas de cada país, ficou fragilizado. Não houve o desembolso previsto do Brasil, tampouco do Japão e de Moçambique. Jogos de interesses entre governos e empresas e diferentes percepções culturais compõem o quadro mais amplo no qual o projeto está inserido.

Tendo em consideração as críticas ao ProSavana apresentadas anteriormente, algumas questões merecem ser respondidas: seria a Embrapa, como instituição técnica, apenas uma peça para desviar a atenção do jogo de oportunidades traçado pelos governos? Um diálogo transparente, respeitando os aspectos socioculturais, foi "esquecido", não planejado ou propositadamente não realizado? Ainda que fosse possível por parte da Embrapa a utilização de todos os recursos previstos para a implementação completa do Projeto ProSavana - PI, ele ainda seria exitoso?

O próximo capítulo traz excertos das entrevistas realizadas com diferentes atores da Embrapa, JICA, ABC e acadêmicos, e apresenta as principais tensões, desafios e possíveis oportunidades da CTPD brasileira frente ao Projeto ProSavana. 


\section{DISCURSO DA EMBRAPA E DISCURSO DOS COOPERANTES}

O capítulo destaca alguns trechos de documentos institucionais e das entrevistas, considerados relevantes ao propósito da dissertação e agrupa-os em tópicos específicos.

No capítulo introdutório, que trata sobre o referencial teórico, foi apresentada a metodologia de coleta de dados e análise. Por meio das narrativas e memórias dos cooperantes brasileiros, que estiveram à frente da execução dos projetos, foram extraídas suas percepções. Sabe-se que "a história oral não é necessariamente um instrumento de mudança, [...] não obstante pode ser um meio de transformar tanto o conteúdo quanto a finalidade da história" (THOMPSON, 1992, p. 22).

Foram ouvidos líderes de projetos e gestores, analistas e pesquisadores que atuam nos projetos de cooperação da Embrapa. Foram ouvidos doutores, mas também estudantes que estão em trabalho de pesquisa de campo, realizando entrevistas e se aprofundando em projetos de cooperação internacional com a África. De acordo com Thompson (1992, p. 23), "no sentido mais geral, uma vez que a experiência de vida das pessoas de todo tipo possa ser utilizada como matériaprima, a história ganha nova dimensão".

\subsection{Discurso Institucional}

Os discursos das instituições, sejam eles publicados em documentos ou expostos em suas falas, servem de informação para a opinião pública. Para análise da coerência entre as estratégias discursivas sobre transferência de tecnologia extraídas dos textos escritos ou orais, realizada em seção posterior, foram compiladas explicitações nos principais documentos da Empresa e reuniões.

\subsubsection{Embrapa: da difusão e transferência de tecnologia para a construção coletiva do conhecimento}

No capítulo "Os registros históricos e o passado da Embrapa com olhos do presente" foram apresentadas referências e memórias que destacam a trajetória da Embrapa, principalmente a partir de uma abordagem difusionista. "Esta perspectiva operacional respondeu e ainda responde questões importantes para o setor agropecuário" (EMBRAPA, 2015, p. 8). 
Nesta seção, para a análise do discurso institucional, foram utilizados como principais documentos de referência o Estatuto da Embrapa, o V Plano Diretor da Embrapa (PDE) - 2008-2011-2023 e o documento Visão 2014-2034: o futuro do desenvolvimento tecnológico da agricultura brasileira. São documentos ainda vigentes. Somaram-se, ainda, trechos das narrativas de reuniões da Diretoria Executiva, na tentativa de analisar comparativamente os textos escritos e os narrados na atualidade.

De acordo com o Estatuto da Embrapa, aprovado pelo Decreto ํo 7.766/2012, da Presidência da República (com particular referência para o Art. 5),

Em sua atuação internacional, são objetivos da Embrapa: I-facilitar e
acelerar a solução de problemas, a busca de oportunidades e o
fortalecimento da agricultura brasileira, no que se refere a ações
internacionais; II - planejar, orientar, promover a execução, executar e
supervisionar atividades de pesquisa e desenvolvimento, transferência de
tecnologia agropecuária e de incentivo aos talentos nacionais para
produzir conhecimentos tecnológicos que fortalecem a agricultura brasileira
e a dos países em desenvolvimento (BRASIL, 2012, grifo nosso).

Além disso, conforme a diretriz 5 do V Plano Diretor da Embrapa (2008-20112023), a Empresa busca

[...] expandir a atuação internacional em suporte ao desenvolvimento da agricultura brasileira e à transferência de tecnologia" e, para este fim, busca 'construir parcerias nacionais e internacionais para projetos de PD\&I em consonância com os Objetivos Estratégicos da Embrapa' (EMBRAPA, 2008, p.26).

Nesse sentido, a Embrapa também entende que "a cooperação técnica é um importante instrumento do Governo Brasileiro para apoiar ações de capacitação e transferência de tecnologia em países em desenvolvimento" (EMBRAPA, 2014g).

No âmbito nacional, conforme explicitado abaixo, a Embrapa tem realizado, junto aos seus parceiros, algumas ações de aproximação entre os atores e que focam as especificidades regionais. $O$ assessor do Departamento de Assistência Técnica e Extensão do Ministério do Desenvolvimento Agrário (MDA), Hur Ben Correa da Silva apresentou, em reunião na sala da Presidência da Embrapa, em 28 de julho de 2014, alternativas que já vem sendo trabalhadas, como os eventos de concertação, ou seja, segundo ele, "um encontro de se conhecer e fazer agendas em conjunto na perspectiva de trabalhar a inovação." Ele acrescentou ainda:

Estamos trabalhando na lógica da oferta. Deveria ser na lógica de construção de soluções. Sistematizamos conhecimentos científicos a partir de demandas, anseios, gargalos. Precisamos de soluções apropriadas nas 
mais diversas áreas rurais. É mais que ciência, é arte. Convergir na possibilidade de diálogos. Às vezes é ajustar o que eles já estão fazendo (REUNIÃO EM 28 DE JULHO DE 2014).

Segundo Hur Ben, um exemplo de trabalho, utilizando uma dinâmica que envolve a comunidade foi o projeto Mais Alimentos, do MDA, um programa brasileiro que financia investimentos na modernização de propriedades rurais. Desde 2010, inclusive, foi lançado um braço do programa, em uma primeira fase, voltado a negócios no exterior em Zimbábue, Cuba, Moçambique, Senegal, Gana e Quênia.

O Estatuto da Embrapa, com referência para o Art. 5, citado anteriormente, indica contribuir para "embasar suas iniciativas relevantes de cooperação técnica em conhecimentos atualizados e soluções tecnológicas apropriadas para o contexto social, econômico e cultural específico de cada população envolvida" (BRASIL, 2012, grifo nosso).

Nesse sentido, de conhecer as demandas regionais, o Diretor de Transferência de Tecnologia da Empresa, Waldyr Stumpf Júnior afirmou:

Visão é sonho. Sonho está se tornando realidade. Chegar mais perto da
sociedade, ouvir a sociedade, perceber suas necessidades e buscar
convergência (REUNIÃO EM 28 DE JULHO DE 2014).

Essa ideia de aproximar a pesquisa da sociedade não é recente. $O$ expresidente da Embrapa Alberto Duque Portugal, que presidiu a instituição de maio de 1995 a janeiro de 2003, citou em entrevista para um projeto que resgata a memória da Empresa:

Os projetos precisam começar e terminar no consumidor. A Embrapa reforça seu enfoque para o meio ambiente e para a agricultura familiar. Está presente nos assentamentos, em reservas indígenas, pequenos municípios do interior, cumprindo seu papel de Instituição pública, movida pelo interesse social (CABRAL, 2005, p. 207).

Sílvio Crestana, também ex-presidente da Embrapa, apresentou a mesma abordagem em entrevista ao pesquisador Irineu Cabral, para o mesmo projeto:

A Embrapa é pública e precisa atender demandas vindas de todos os segmentos, dos pré-assentamentos às esferas mais privilegiadas do agronegócio (CABRAL , 2005, p. 238).

Sobre a cooperação com a África, a Embrapa defende que:

[...] compartilhando conhecimentos e experiências tecnológicas por meio de capacitação de recursos humanos, execução conjunta de projetos, assistência técnica, consultoria e outras formas de cooperação, a Embrapa e as instituições parceiras africanas estão irmanadas no propósito de 
contribuir para a elevação dos índices de produção e produtividade das lavouras, o aumento de renda e a redução da pobreza na África (EMBRAPA, 2011, p. 1).

No site do Itamaraty é informado que:

[...] a cooperação técnica sul-sul brasileira caracteriza-se pela transferência de conhecimentos, pela ênfase na capacitação de recursos humanos, pelo emprego de mão-de-obra local e pela concepção de projetos que reconheçam as peculiaridades de cada país; com base na solidariedade que marca o relacionamento do Brasil com outros países em desenvolvimento, livre de condicionalidades, construída a partir da manifestação de interesse de parte dos parceiros ("demand driven"), a partir de uma relação de parceria na qual as partes envolvidas se beneficiam, ou seja, adota o princípio da horizontalidade na cooperação, e fundamentado no princípio constitucional da cooperação entre os povos para o progresso da humanidade" (BRASIL, 2014).

Conforme descrito no PDE, os valores institucionais da Empresa "balizam as práticas e os comportamentos da Embrapa e de seus integrantes, independentemente do cenário vigente, e que representam as doutrinas essenciais e duradouras da empresa" (EMBRAPA, 2008, p. 18). Em particular, no que diz respeito à responsabilidade socioambiental (valor 2), a Embrapa afirma interagir "permanentemente com a sociedade, na antecipação e na avaliação das consequências sociais, econômicas, culturais e ambientais da ciência e da tecnologia", assim contribuindo "com conhecimentos e tecnologias para a redução da pobreza e das desigualdades regionais" (EMBRAPA, 2008, p. 18).

O PDE enfatiza, quanto à cooperação (valor 6), que a Embrapa valoriza "as atitudes cooperativas, a construção de alianças institucionais e a atuação em redes para compartilhar competências e ampliar a capacidade de inovação, e, para isso, mantermos fluxos de informação e canais de diálogo com os diversos segmentos da sociedade" (EMBRAPA,2008, p. 19).

O documento Visão 2014-2034, desenvolvido recentemente, exprime a necessidade de "desenvolver estratégias para ampliar a sinergia entre as ciências cognitivas, sociais e econômicas para tratar questões da dimensão humana e das relações com a sociedade com o mundo rural (sic.)" (EMBRAPA, 2014a, p. 50).

A autora buscou publicações e normativas atuais sobre o modelo de transferência de tecnologia atual da Empresa. Foi identificado um marco referencial, elaborado pelo Departamento de Transferência de Tecnologia, em estágio de avaliação pela Diretoria, cuja apresentação do Diretor-Presidente Maurício Lopes enfatiza a necessidade de mudança das instituições: 
Ao se admitir que o desenvolvimento se dá no local, as instituições de ciência e tecnologia e de extensão precisam administrar outra complexidade, que vai além da difusão de tecnologias. As instituições agora precisam interagir com os sistemas e entendê-los, para depois agir com segurança e talvez provocar mudanças significativas. Foram estas paradigmáticas mudanças, das regras da oferta para as de consumo que definiram os novos desafios. A sociedade mudou e as instituições também precisam mudar (EMBRAPA, 2015, p. 3).

Ele ainda argumenta:

A Embrapa precisa dialogar constantemente com seus diversos parceiros e saber das expectativas e necessidades do setor agropecuário e da sociedade brasileira. Assim, este marco referencial visa orientar a interação da Embrapa com a sociedade (EMBRAPA, 2015, p. 3).

\subsection{Discurso dos cooperantes e especialistas}

Nesta seção são apresentados os discursos dos cooperantes brasileiros e dos acadêmicos, obtidos por meio de entrevistas semiestruturadas. São destacados alguns dos trechos das entrevistas mais relevantes ao argumento central desta dissertação, ou seja, que o projeto ProSavana não considerou as dimensões culturais envolvidas na sua implementação.

Para suportar esse argumento foram identificados, por meio das entrevistas, alguns desafios percebidos, bem como foram apontadas algumas das principais oportunidades do ProSavana-PI.

5.2.1. A experiência de cooperação da Embrapa no projeto ProSavana frente aos seus principais desafios

Os cooperantes e acadêmicos citaram, a partir de suas experiências e estudos, os principais desafios enfrentados, que são agrupados e apresentados a seguir.

Decisões governamentais: o corte de recursos do ProSavana

Segundo os informantes, a falta de apoio de vários governos aos avanços da pesquisa e o oscilante reconhecimento positivo da sociedade por suas ações deixa a Empresa, em vários momentos, vulnerável às críticas. No caso do ProSavana, um técnico da Embrapa comentou: 
_ Algumas pessoas preferem não estar associadas ao projeto (referindo-se ao ProSavana) tão mal falado. O Governo não fala nada. Quem cala consente.

_ Quem fala parece que tem razão. Por sermos eficientes ainda somos criticados (REUNIÃO INTERNA, EM 06 DE AGOSTO DE 2014).

A respeito do reconhecimento, um informante mostrou-se satisfeito, pelo menos quanto às relações com o governo moçambicano:

Existia confiança total. Não se faz cooperação se um dos parceiros não quer. O Governo moçambicano que pediu ajuda da Embrapa. Tinha confiança na Embrapa pelo seu reconhecimento frente às áreas tropicais (INFORMANTE INTERNO 11).

Em reunião interna, em 06 de agosto de 2014, na qual a autora participou, os técnicos da Embrapa afirmaram, entre os principais desafios enfrentados no ProSavana-PI, o corte de recursos do Governo Federal que acarretou na falta de repasse pela $A B C$ :

Deve-se ressaltar que parte significativa dos recursos (equipamentos Taboratoriais, máquinas e implementos agrícolas, insumos agrícolas, logística de viagens) originalmente planejados não foi disponibilizada nem em tempo e nem em suficiência.

_ Foi enviada a listagem das necessidades e até possíveis fornecedores, no entanto os itens não foram comprados (referindo-se a $A B C$ ). A ausência de equipamentos fez com que vários trabalhos tenham sido feitos à mão, gerando, inclusive, atraso (REUNIÃO INTERNA, EM 06 DE AGOSTO DE 2014).

Na mesma reunião, foram apontados alguns dos impactos da falta de recursos:

_ A demora para liberação de veículos impactou na capacitação dos alunos.

A falta de máquinas e equipamentos agrícolas solicitados acarretou na dependência da contratação de largo contingente de mão-de-obra local, embora carente quanto à capacitação e à qualidade requerida pelos trabalhos de pesquisa.

_ As análises de solo, indispensáveis para a interpretação dos dados gerados nos experimentos, encontram-se severamente prejudicadas em decorrência do cancelamento da construção do Laboratório de Multianálise, em Lichinga (REUNIÃO INTERNA, EM 06 DE AGOSTO DE 2014).

Outro informante acrescentou impactos decorrentes da falta de recursos, como o cancelamento de missões, a falta de compra de material, e consequentemente a frustração por parte dos técnicos da Embrapa e IIAM:

Por decisão do governo foi cortado o recurso e isso gerou cancelamento de missões. Foram feitas manifestações para mostrar os prejuízos. Para o componente 2 fizemos visita, todo um planejamento: flora, fauna, qualidade 
de água, para dar continuidade. Quando seria a missão para realizar a capacitação e dar andamento, a ABC não comprou o material. Quando isso acontece, você perde o contato com os parceiros, gera expectativa (INFORMANTE INTERNO 11).

Entre os técnicos da Embrapa, nessa reunião, havia um discurso comum. Prevalecia entre os participantes a percepção das perdas relacionadas ao corte de recursos e ao impacto delas, seja no andamento do Projeto ou nas relações interpessoais com a JICA Além de vivenciar impactos tangíveis relacionados com a carência orçamentária, os técnicos da Embrapa sentiam-se constrangidos e inferiorizados nas relações de parceria com a JICA:

A ABC ao não disponibilizar aos Centros Zonais do IIAM os recursos
previstos no projeto, colocou os pesquisadores japoneses em posição mais
simpática diante da equipe de pesquisadores do IIAM e a contraparte
brasileira em posição devedora frente ao inicialmente programado. Para tal
é necessário o atendimento efetivo das demandas planejadas no projeto.
Mudanças de curso, como contingenciamento de recursos, cancelamento
de atidades essenciais, tais como máquinas e implementos agrícolas,
missões de acompanhamento técnico, têm comprometido a qualidade dos
resultados esperados do projeto neste componente (REUNIÂO INTERNA,
EM 06 DE AGOSTO DE 2014).

Um técnico, na mesma reunião, ainda comparou:

Precisa ser comentado sobre a dificuldade de lidar com as contrapartes. Japoneses pagam secretária japonesa, motoristas bilíngues (REUNIÃO INTERNA, EM 06 DE AGOSTO DE 2014).

Um grupo apresentou seus depoimentos:

_Os japoneses fazem tudo certinho, fazem além, e colocam a gente em constrangimento.

_O lado japonês supera a meta.

A Embrapa conversou com os japoneses, dizendo que darem benefícios para os trabalhadores dificultava a relação entre os brasileiros $\mathrm{e}$ moçambicanos.

_Éramos os primos pobres da parceria.

Os japoneses apresentavam todo dia uma planilha de desembolso e os brasileiros, nada. (REUNIÃO INTERNA, EM 06 DE AGOSTO DE 2014).

Um colega contra-argumentou:

A JICA tem 40 anos de tradição. Eles já aprenderam a lidar com isso (REUNIÃO INTERNA, EM 06 DE AGOSTO DE 2014).

Outro colega ressaltou: 
O governo em Moçambique está satisfeito (REUNIÃO INTERNA, EM 06 DE AGOSTO DE 2014).

Quanto à imagem embrapiana diante dos pesquisadores do IIAM e da JICA alguns se preocuparam mais, outros menos. Na reunião, principalmente por meio de várias apresentações em power point, foram apresentados os resultados alcançados, mas não havia muito a comemorar, sendo que muitos desse resultados estavam baseados no sacrifício dos próprios técnicos. O clima geral era de frustração, decepção, preocupação e desânimo. Por outro lado, havia também vontade de fazer mais e melhor,

A semeadora foi conseguida por doação. Como diz o [o colega], 'precisando a gente faz' Utilizei dia de folga para conseguir as doações das matracas.

[...] Um colega pegou malária e passou o réveillon no CTI. Perdeu um rim (REUNIÃO INTERNA, EM 06 DE AGOSTO DE 2014).

Quando entrevistados, os informantes externos 2 e 5 lamentaram as dificuldades enfrentadas pelos técnicos da Embrapa para execução do projeto:

Tenho dificuldade em entender a questão das missões, não é culpa da Embrapa. Houve bastante enxugamento do recurso da ABC. A Embrapa programou tudo lá, fizeram um cronograma. Só que tem hora que não consegue implementar por causa dos cortes no orçamento. Dificuldade da parte da Embrapa, porque a cooperação internacional precisa passar pela $A B C$ (sic). A JICA dentro do orçamento tem definido a responsabilidade de cada parte. O Brasil ficou responsável pelo envio dos técnicos e pela criação de um laboratório. O laboratório da JICA no final do ano fica pronto e da $A B C$ não. (INFORMANTE EXTERNO 2).

O empregado da Embrapa tem muito amor à camisa. Profissionalmente não acho correto. Do ponto de vista humano, sim. Mas a ABC deveria repassar o recurso e se é pra valer, tem que ser feito direito. Faz o orçamento, mas se diz que vai pagar, tem que pagar. Senão não é sério o processo. Tem uma quebra de confiança, porque quem está lá depende desse recurso. Eles contam com isso. Acho vergonhoso para a imagem do Brasil, perante, inclusive aos japoneses, que vão ser atenciosos, vão dar o dinheiro, mas que por trás, entre eles, vão achar um absurdo. O que acharia um inglês, um alemão? Falam sobre as diferenças entre desenvolvidos $\mathrm{e}$ subdesenvolvidos, mas está aí um traço de subdesenvolvimento: não cumpre os compromissos, usando uma estratégia de fato consumado. Você tem que ser o que é. Fala logo que não pode e não cria expectativa que vai frustrar os outros. Agora uma coisa é criar expectativa e a outra é não ser organizado. Precisa fazer o orçamento da maneira adequada, colocar as rubricas nos locais certos, fica tirando de um lugar para colocar no outro, ao sabor das autoridades de plantão. Chega um cara novo, diz que vai reinventar a roda e tudo bem. A base disso tudo está na falta de um sistema de cooperação internacional. Não basta se atribuir o papel de quem faz cooperação internacional, tem que ter vários stakeholders. Precisa ter cobrança dos programas. Ver como o Brasil está diante desses resultados. Discutir com as ONGs envolvidas (INFORMANTE EXTERNO 5). 
O informante externo 6 destacou que, apesar da limitação de recursos, os técnicos da Embrapa mantiveram seu comprometimento com o trabalho:

Sempre foi comentada a dificuldade da cooperação por causa da limitação do recurso. Sempre destaquei que mesmo diante da limitação, o nível técnico esteve comprometido. Não houve diminuição do aporte técnico de forma significativa. A ABC cortou recursos, tirou o laboratório de Lichinga. Mas não teve diminuição do aporte técnico da Embrapa (INFORMANTE EXTERNO 6).

Segundo a maioria dos informantes, os cortes de orçamento da ABC afetaram o projeto. No entanto, segundo um único entrevistado, a questão não gerou estremecimentos:

A gente já vem trabalhando em parceria, não é de hoje. O orçamento, conforme a economia, reduz ou aumenta. Não dá para querer uma coisa que não tem. Discutir para encontrar uma forma (INFORMANTE EXTERNO 2).

Diante da dificuldade no repasse do recurso, a JICA, por fim, assumiu a construção do laboratório; ao contrário, a Embrapa, conforme o informante externo 6, não realizou a missão negociada:

Em maio foi feita esse negociação e Moçambique e Japão foram lá
conversar. Ficou definido que a Embrapa faria uma atualização do perfil dos
profissionais, do corpo técnico para alocar no laboratório. A Embrapa iria em
novembro ao país, mas cancelou a missão por causa da pessoa da
engenharia que coordenaria a missão e que disse que não poderia ir. Foi
um desgaste muito grande. Depois do desgaste que foi negociar o
descumprimento da construção do laboratório, a única coisa acordada,
ainda, não foi cumprida. Estamos aguardando uma palavra da SRI. Em
dezembro teve essa indicação que seria em fevereiro. Teve um ponto de
honra de realizar essa missão. A Jica disse que só poderão avançar
mediante a apresentação desse trabalho da Embrapa. Assim o processo de
finalização do Projeto parou. Encerrou o ano fiscal do Japão. Agora, eles
querem tirar do projeto a construção do laboratório (INFORMANTE
EXTERNO 6).

Conflitos internos e jogos de poder ${ }^{27}$

No tocante às questões internas, as preocupações dos cooperantes embrapianos com relação ao apoio da $A B C$ iam além da necessidade de recursos. Os técnicos também precisavam contar com o apoio da Agência para fazer "gestão junto ao governo moçambicano", minimizar cobranças e possíveis conflitos internos:

\footnotetext{
${ }^{27}$ Comunga-se da visão de Michel Focault (1926-1984), filósofo francês.
} 
A missão da Embrapa no componente 4, de gerar e difundir informações, conhecimentos e tecnologias que demonstrem e assegurem a viabilidade técnica e econômica da agricultura no Corredor de Nacala, está bem definida, porém a pressão da sociedade civil moçambicana faz com que sejamos cobrados por ações com ênfase para a agricultura familiar. Estas ações são contempladas pelo componente 5 , que não faz parte do ProSavana -PI, mas do ProSavana - PEM. Há necessidade de que a ABC faça a gestão junto ao governo moçambicano para que este tenha aquela postura de salvaguarda do que foi acordado no projeto original (REUNIÃO INTERNA, EM 06 DE AGOSTO DE 2014).

Em uma reunião entre técnicos brasileiros e moçambicanos, um técnico da Embrapa comentou:

O componente político é forte. Vejo necessidade de discussões técnicas. Eles (referindo-se aos moçambicanos) respondem: 'Nosso problema não é com vocês. É com o Governo. Não queremos conversa, queremos sementes' (REUNIÃO INTERNA EM 07 DE AGOSTO DE 2014).

Por outro lado, o informante interno 12, ao ser entrevistado, disse que não percebia conflitos:

Que conflito? Não houve conflito. Na possibilidade de conflito, o Projeto parou. O Brasil andou devagar, porque o problema não era nosso. O projeto foi concebido no Governo Lula e executado no Governo Dilma. Ela não deu importância. O lado japonês não teve condições. O lado brasileiro não teve condições. Já o Governo Moçambicano é um exímio negociador. Quer receber a cooperação. Quer ganhar alguma vantagem. Para você ter uma ideia, $60 \%$ do orçamento do Governo era doação (INFORMANTE INTERNO 12).

Os informantes externos 5 e 1, assim como o informante interno 11 abordam com criticidade os problemas do ProSavana em Moçambique, mas não responsabilizam a Embrapa diretamente. Enquanto o informante 5 levanta que existe "um jogo maior acontecendo lá", o informante 1 indica a Unac, como um dos principais atores desse jogo de poder.

O meu conhecimento do ProSavana que não é extenso, mas até onde sei a participação da Embrapa é precisa e focalizada. Fazer áreas de testes para sementes em determinados terrenos, levando em consideração o solo. Não sei se eles estão fazendo análise de bactérias que usaram no cerrado. Como alguns pensam fazer a reprodução do que teve aqui no Cerrado, mas é impossível reproduzir em Moçambique. Testam variedades de plantas e em cada planta, a soja, o algodão para ver qual a melhor se aplica lá. O que eu quero dizer é que a Embrapa não entra no jogo maior, porque tem um jogo muito maior acontecendo lá. Fazem treinamento, capacitação, até de uma maneira básica, com aquela cartilha que vocês prepararam, que até foi uma coisa boa. A relação com a $A B C$ foi surreal. Com pessoas que falei, a moça da $A B C$ só atrapalhou. A Embrapa fica quase como um prestador de serviço. A participação não entra na questão férrea, energética do carvão, relações internacionais ou o porquê a linha férrea cruza o Malaui. Até onde 
pude perceber, o papel da Embrapa é acessório, mas um acessório importante para um cinturão verde no corredor de Nacala, cuja principal função é a exportação do carvão por meio dessa ferrovia. Querem duas coisas: um cinturão verde, cultivos de commodities, dois: soja e algodão e os de subsistência: agricultura familiar (sic). Com a finalidade de grandes latifúndios, fontes de renda para o país que favoreça a balança comercial de Moçambique. Por uma série de protestos que foram criados lá com apoio internacional contra o governo brasileiro e japonês. Uma forma de mitigar esses processos é achar uma maneira de sustento para essas populações (INFORMANTE EXTERNO 5).

O informante externo 1 acentua o jogo de cada ator por garantir os seus próprios interesses:

Os projetos têm interesses contraditórios. O ProSavana era mais um, no qual as comunidades gerais abrangidas viam como forma positiva pela possibilidade de receber os recursos. Depois é que houve uma especulação a partir da colocação do Pacheco ${ }^{28}$, Ministro da Agricultura de Moçambique, que havia sugerido que Moçambique havia terras disponíveis. Daí que surge o posicionamento da UNAC contra o ProSavana. A Unac achou que era uma possibilidade de reforçar sua luta. Faz parte de um jogo político para ganhar espaço no campo internacional.

Querem se aproveitar do Programa para ganhar espaço. A Unac começa a receber financiamento, não para criar polêmica, mas para se beneficiar do ProSavana para reforçar seu papel, em uma visão cínica. Afinal há um lado negro da contestação altamente oportunista. Importante ver diferentes lados na questão, as verdades dentro de diferentes pontos de vista. São muitas agendas que devem ser consideradas. Falando com vários atores, polarizase o debate, exigindo que esteja de um lado ou de outro (INFORMANTE EXTERNO 1).

Com relação ao relacionamento com a Unac, o informante interno 11 afirmou:

A Unac tem um movimento de esquerda, junto com a Classen que tem uma linha de campesinato, uma linha de perpetuação da pobreza. Não havia projetos que tirariam os camponeses. Foi esse grupo que agiu de forma a criar obstáculos. Isso não é relacionado à Embrapa. Quando éramos chamados a falar sobre isso, os projetos não foram discutidos. Falamos com o governo, com pessoas que trabalham com todo esse pessoal, agentes da extensão, os legítimos representantes desse campesinato. Essas críticas vieram bem depois de eu já ter conversado com todos, Unac, Ikuro, uma outra organização. Foram diálogos fáceis. A Unac de Nampula foi ao campo com eles. Pessoal engajado. Tem dirigentes que conhecem a realidade. Muito interessante. Pena que não conseguimos lidar com 0 projeto dentro do planejado. O trabalho era de entender melhor e conhecer as comunidades (INFORMANTE INTERNO 11).

Assim como o informante externo 5 e o informante interno 11, o informante externo 1 entende que a Embrapa está afastada dessa polêmica. Nesse trecho da entrevista, ele cita:

${ }^{28}$ José Condugua António Pacheco - Ministro da Agricultura de Moçambique. 
A Embrapa me parece afastada da polêmica, seja por não fazer parte da polêmica ou se houve um recuo para proteção da imagem. [Um dos cooperantes] apresenta o ProSavana como um projeto da FGV. Descolaram a Embrapa do ProSavana. Não sei se isso foi feito em reação à polêmica ou se nunca se apropriou do programa. O componente da Embrapa não é o componente mais critico (INFORMANTE EXTERNO 1).

Um informante externo percebe que a própria cooperação é uma área de debates e lutas políticas e apresenta suas preocupações:

A questão é que a cooperação é uma área também de debates e lutas políticas muito fortes. O risco é que essa cooperação que se diz desinteressada e horizontal e alternativa seja apropriada por interesses essencialmente comerciais que não beneficiam aqueles que precisam ser mais atendidos na África. Alguns governos africanos são o principal problema. As elites quase sempre se apropriam do estado. Na África isso é o que está a se verificar. Se os Governos querem uma cooperação aliada a interesses corporativos dominados por elites... O Brasil tem uma diplomacia, mas não vai cooperar com países corruptos. Mas pode ajudar por ingenuidade e não estudar previamente as realidades locais. As questões precisam ser levantadas (INFORMANTE EXTERNO 1).

Em termos da cooperação internacional em si, o informante externo 6 tentou explicar que:

O investimento inicial do ProSavana foi orientado a reconhecer a visão do próprio governo. Não deveria ser um plano pronto, desenvolvido aqui e implantado no exterior. Quando executado, inclusive, o grupo teve oportunidade de entender os problemas das províncias, os jogos de poder nas comunidades rurais, as relações nos distritos com as lideranças locais. Essas relações de poder e autoridades formais permitiam que o programa tivesse oportunidade de envolver diversos grupos de atores em várias instâncias para não ter somente a visão da capital, do governo central (INFORMANTE EXTERNO 6).

Segundo esse informante, o Projeto não previa uma interação com os beneficiários, mas com o Minag e o IIAM, com foco em aprimorar as capacidades técnica dos profissionais:

O ProSavana teve em sua primeira fase atividades voltadas para 0 fortalecimento das instituições, no caso o IIAM. Não foram previstas relações com outros atores. A fase posterior ao PD começaria a ter ação mais direta. Em termos de cronologia talvez possa ser questionada. A relação ficou muito centrada no Minag e no IIAM. As duas instituições eram o alicerce do projeto, em termos de aprimorar as capacidades dos órgãos dos estados e fazer o reconhecimento, então, de como o estado é organizado. Na perspectiva de uma mudança e dinamização da agricultura em Moçambique, as instituições moçambicanas estariam preparadas para essa modernidade. Isso significaria também um potencial avanço para as políticas públicas. Dezoito meses de acordo político e na construção do programa houve um direcionamento de fazer, de abrir as portas de forma clara, positiva. Fizemos a identificação de grupos, das províncias... No Plano deveria integrar com a Unac. Por parte do Governo não houve dificuldade. Sempre teve uma relação que permitia. No desenho, na fase inicial, não tinha a abrangência de trabalhar com os beneficiários. $O$ foco 
era trabalhar com os órgãos do estado. A capacidade alargada permitirá uma relação com os beneficiários. A cooperação internacional é temporária. Se não se construir uma relação com o Estado, não vai se construir isso. Até entender as dificuldades do Estado para o desenvolvimento, faz parte das dificuldades iniciais (INFORMANTE EXTERNO 6).

Ele, ainda, informou que as relações com a Unac a princípio eram boas, mas que na implementação do Projeto ocorreram motivações externas:

Até metade da execução do ProSavana-PI nunca teve oposição no nível provincial com relação às organizações sociais. Até vir a primeira manifestação da Unac de Maputo, não havia oposição. O Projeto não tinha atividades diretamente com eles. Tivemos um processo completo para entender como essas forças, além do governo central, estavam se posicionando (INFORMANTE EXTERNO 6).

Na sua percepção, as críticas partiram das ONGs brasileiras, tendo em vista que havia uma boa aceitação anterior da Unac em Moçambique. Na opinião dele, a Unac de Maputo foi instrumentalizada por ONGs locais:

Tivemos reunião com a Unac de Maputo, com a Oram e Justiça Ambiental. Claramente o que ocorreu foi que a notícia que saiu no Brasil sobre o ProSavana motivou uma posição de que o processo de desenvolvimento do cerrado não foi um processo que ajudou as populações originais e que aqui trouxe problemas no campo. Pela leitura externa, estaríamos levando esse modelo para Moçambique. ONGs brasileiras criticaram esse modelo. E é um programa totalmente diferente. Houve conversa com as ONGs do Brasil, tentando transmitir o que era o programa. Para eles, o envolvimento da Embrapa, que trabalha para médio e grande agricultura e o envolvimento da FGV-Agro significava que o ProSavana tinha esse enfoque. A primeira manifestação da Unac foi bem aceita no Brasil. No entanto, o texto que tivemos acesso estava em português brasileiro. Questionamos e eles não gostaram que alguém pensasse que eles foram instrumentalizados. Foi alvo de autocrítica da coordenação do ProSavana. No início, a Unac foi consultada e eles perguntavam quando o ProSavana ia chegar. Na primeira fase não tinha contato (INFORMANTE EXTERNO 6).

Um informante interno informou que, entre os primeiros trabalhos realizados, houve uma visita à Unac:

O projeto foi desenhado pelos técnicos de diferentes governos. Quem deu as diretrizes foi o governo moçambicano, Ministério da Agricultura. $O$ Projeto prevê componente específico para pequenos produtores. Teve os primeiros ensaios. Um dos primeiros trabalhos foi visitar as comunidades. Visitamos a Unac pessoalmente. Juntos, escolhemos as comunidades, conversamos com as comunidades. Teve uma decisão de Brasília que esse componente aconteceria no segundo ano. O chefe do componente 5 marcava reuniões, mas não avançou, por causa de orientações de Brasília. O próprio pessoal da Embrapa não quis, porque surgiu outra proposta da FAO. Esse assunto foi levado para a chefia da SRI. Ficou nessa situação por questões internas da própria empresa, mas eu acho que era importante (INFORMANTE INTERNO 11). 
O informante interno 11 deixa claro que o não andamento do componente 5 , por motivações, inclusive, internas, prejudicou o Projeto como um todo. Ainda que tenha havido alguma interação inicial com as ONGs, um cooperante brasileiro assume que no Projeto houve falhas de comunicação com essas organizações:

\begin{abstract}
Eles não sabiam o que faria o $\mathrm{PI}$, o que faria o PD. As organizações tinham comentado que, embora o resultado final não fosse o que eles queriam, 0 Pedsa - Plano de Diretrizes para o Desenvolvimento da Agricultura tinha sido conduzido como um processo com abertura para contribuições da sociedade civil. Tentamos explicar que o ProSavana não era um outro plano. A gente explicava que não era um Pedsa, nem o Pnisa - Plano Nacional de Investimentos para o Setor Agrário em Moçambique, mas que seriam usados ambos como documentos norteadores. Entendíamos que se estávamos seguindo documentos desenvolvidos por eles que a harmonização seria possível. Eles não deveriam ver o ProSavana como algo desarticulado. Essa é nossa posição, mas claro que isso não os satisfez (INFORMANTE EXTERNO 6).
\end{abstract}

\title{
O informante externo 6 acrescentou:
}

No segundo ano do Programa, O Diretor Fernando Abreu, o Diretor Geral da JICA e o secretário permanente da Agricultura de Moçambique, Daniel Clemente fizeram uma reunião e foi decidido sobre a necessidade de se criar uma estratégia de comunicação. As críticas referentes ao Programa já avançavam em interpretações equivocadas. Nunca houve entendimento desse tipo de atuação. Não dá para fazer um desenho sem avaliar o todo. $O$ ProSavana não é só de agricultura familiar e nem só de agronegócios. Tem dois pontos muito importantes. Um ponto é que é preciso ampliar a participação da sociedade civil no Programa. A expectativa das organizações em Maputo era positiva de algo que iria contribuir. Depois de dois anos, as pessoas não viam concretamente o que estava sendo feito, do ponto de vista da sociedade civil e dos camponeses. Outro ponto foi a manifestação das ONGs no Brasil que criaram esse movimento de reações de algumas organizações. Isso não é unanimidade em Moçambique. É da capital, mas eles influenciaram as províncias. De toda forma, continua tendo gente interessada no Programa (INFORMANTE EXTERNO 6).

Foi fortemente comentado entre os informantes, principalmente os externos, os jogos de poder entre diferentes atores, direta ou indiretamente, envolvidos no Projeto. Seria a Embrapa um joguete dos Governos para alcançarem seus próprios interesses? Segundo um informante interno:

Não acredito. Não fomos joguete. A cooperação brasileira não é vinculada a outros compromissos. Não foi pedida nenhuma benesse para empresas brasileiras. São ganhos indiretos. O Graziano, da FAO, foi eleito com o apoio da África. No Governo Brasileiro não vi isso. A parte moçambicana queria a tecnologia que nós temos. Tivemos que mostrar que a transferência de tecnologia não se faz assim automaticamente. Deveria fortalecer a equipe técnica do IIAM. Contratar mais técnicos para se ter a quem deixar um legado de compromisso com o desenvolvimento. Os técnicos brasileiros também ganharam muita experiência (INFORMANTE INTERNO 11). 
O informante externo 6 percebeu a situação com a qual os cooperantes brasileiros confrontaram a Unac como um desafio, mas que trouxe aprendizado:

\begin{abstract}
Interessante que todo esse movimento construiu uma rede internacional. Com isso, eles estão muito atentos. Tem coisa absurda que é colocada, mas em geral, de todo modo foi positivo a discussão do assunto sobre o ProSavana, na discussão sobre comunicação, informação. A elaboração do PD sobre o futuro do processo de desenvolvimento terá uma elaboração de consulta pública em Moçambique. O novo governo tomou posse no final de janeiro. A Minag vai conduzir o processo sobre consulta pública para elaboração do PD. Nunca percebemos o interesse de manobrar as opiniões, mas não foi adequada a relação com eles. Com essa pressão houve clara decisão de ter uma consulta ainda sobre o rascunho, o documento de base. A área do Minag que vai conduzir é a área da economia que conduziu o trabalho do Pedsa. Não vão ser ouvidas somente as organizações que se posicionaram de forma a favor ou contrária. Vai ser ouvida a sociedade civil, composta por um conjunto de representantes que inclui organizações do setor privado, academia e representantes dos camponeses. A maior representatividade vai gerar melhor resultado desse processo (INFORMANTE EXTERNO 6).
\end{abstract}

\title{
Desconhecimento sobre a cultura dos países parceiros
}

Entre os entrevistados internos e externos, a maioria afirmou e valorizou a importância de trabalhar em cooperação internacional e transferência de tecnologia, a partir de uma análise do componente cultural. Suas reflexões, indagações e preocupações, advindas da experiência profissional, mostraram que analisar as questões culturais é um dos pontos fundamentais para o sucesso da implantação de um Projeto de CTPD.

Segundo um informante interno,

Em princípio, como as condições edafoclimáticas do corredor de Nacala eram idênticas às do Cerrado, o Prosavana partiu da suposição de que do ponto de vista agronômico as tecnologias desenvolvidas pela Embrapa para - Cerrado seriam facilmente aplicáveis em Moçambique, mas o problema remeteu às questões socioculturais: em que medida tecnologias modernas seriam internalizáveis em um meio social rudimentar em seus meios e fins? Em que medida a replicação do modelo brasileiro promoverá de fato o desenvolvimento da agricultura para reduzir a pobreza no campo e garantir a segurança alimentar? Em que medida as questões agrárias e socioculturais constituem obstáculos ao progresso rural nos moldes da agricultura capitalista? (INFORMANTE INTERNO 2).

O informante interno 14 afirmou:

Não adianta a Embrapa querer atuar, hoje, da mesma maneira que atuou no passado com transferência de tecnologia. Também não resolve tentar replicar a forma de trabalho no Brasil em outro país. É preciso fazer análise socioeconômica (INFORMANTE INTERNO 14). 
O informante externo 6 criticou o modo como ainda é feita a transferência de tecnologia de um país para outro:

Não existe tempo para organizar, adequar o trabalho. É feito uma réplica do que é feito aqui. Em cooperação internacional, tem que ter noção do que é feito antes e do que é feito depois, num processo de fortalecimento das instituições. A cooperação internacional, além de ter um trabalho doméstico, tem que ter no processo um antes e depois. Deve ser compromisso institucional desenvolver um plano de ação, para ser monitorado depois (INFORMANTE EXTERNO 6).

O informante interno 1 também relacionou a transferência de tecnologia com a necessidade de se compreender a cultura do outro:

Quando vai se transferir tecnologia precisa entender a cultura. Tem lagarta religiosa; mulheres têm medo de cascavel, serpente. As mulheres limpam um pedaço da área agrícola, rezam. Elas fazem o trabalho com as crianças penduradas. A transferência de tecnologia deve dar liberdade de escolha com informação (INFORMANTE INTERNO 1).

Outro informante interno ressaltou a importância de gerar maior "conhecimento de ambas as partes":

Tinha que ter um mínimo de conhecimento do terreno, se você quer estimular um tipo de cooperação participativa com benefício para 0 beneficiário. Resumindo, faltam elementos, conhecimentos de ambas as partes. Nós não os conhecemos e eles não nos conhecem para uma intervenção efetiva, eficaz e eficiente (INFORMANTE INTERNO 6).

Um informante externo indicou a importância de se trabalhar com um componente cultural:

A atuação da Embrapa tem sido dificultada por esses desentendimentos. A ideia da cooperação técnica é boa e há uma expectativa positiva por parte dos moçambicanos, mas foi iniciada de forma ingênua. Por isso vejo o componente cultural como importante. Garantir que haja um componente de análise da situação política, cultural... Há uma tentativa, mas exige uma relação de mais longo prazo para contribuir. A estrutura local não existe. As pessoas ficam um ano. Em um ano o que a pessoa faz? A rotatividade de profissionais é alta (INFORMANTE EXTERNO 1).

O informante externo 6 percebe que o componente cultural é imprescindível para o sucesso de qualquer projeto e seu desconhecimento pode ser um ponto de dificuldade para sua efetividade:

É um componente imprescindível: ter a leitura adequada do contexto local, relações e aspectos culturais que envolvem o parceiro. Essa questão não pode ser dissociada da própria execução técnica. O planejamento, a aproximação, a convivência desse grupo deve estar totalmente envolvida em um permanente aprendizado na busca de entendimento sobre a visão e a própria cultura de parte a parte. A cooperação internacional deve ser um veículo para o intercâmbio de conhecimento e transferência de informação, 
Segundo ele,

tecnologia, tendo sempre em consideração a realidade e questões que envolvem a visão do outro. A própria percepção do ponto de vista do outro é um desafio permanente. Pode ser um ponto de dificuldade para o projeto ser bem sucedido (INFORMANTE EXTERNO 6).

No caso do ProSavana, o projeto foi construído e se teve preocupação com esse componente. Também se percebia pontos de desafio e dificuldades (INFORMANTE EXTERNO 6).

Foi indicada, em reunião interna, a dificuldade na aprendizagem do recipendário moçambicano:

Precisa ensinar a usar a balança. Imagina usar um laboratório requintado? (REUNIÃO INTERNA EM 07 DE AGOSTO DE 2014).

Outro informante interno fez uma ponderação semelhante:

Querem levar uma Ferrari, para quem não sabe pedalar uma bicicleta! Deveria ter sido feito um estudo sociocultural antes. No ProSavana foi feito um planejamento, mas a execução foi desastrosa (INFORMANTE INTERNO 2).

A questão cultural foi apontada como um desafio determinante para o não andamento do Projeto:

Se a coisa não andou, não foi por causa da cúpula, mas da cultura moçambicana. O Brasil cresceu, porque tinha um sistema de crédito e terras baratas. O produtor fazia o financiamento no Banco e comprava a terra, criava a lavoura, depois plantava gado, fazia um sistema de irrigação. Em Moçambique, a terra é do Governo. Eles plantam na terra do Governo, mas eles entendem que aquela terra é de todos eles. No projeto ProSavana, o Governo que faria o projeto-piloto (INFORMANTE INTERNO 12).

Ele acrescentou ainda que:

A área tem uma viabilidade para produzir fantástica. Agora se fizer uma análise, culturalmente, a população não enxerga assim. A terra é mais importante. A produção não os motiva. Eles têm uma experiência de lidar com a fome diferente. Não querem uma cultura de fora. Preferem manter a situação como está. Eles são guerreiros. Tem tribo pacífica e tribo guerreira. São acostumados com guerra e fome (INFORMANTE INTERNO 12).

O informante externo 5 salientou as diferenças culturais e possíveis enfrentamentos entre brasileiros, japoneses e moçambicanos:

Para o japonês é mais complicado, mas a cultura brasileira é mais próxima daquela moçambicana. Até onde pude ver, as limitações acadêmicas são grandes. Isso retrai a pessoa, fica mais cuidadosa com o que fala, principalmente se está em papel decisório. Acho que o Brasil tem muito a cultura negra envolvida. O próprio [líder do projeto] é negro. Se estivesse nos Estados Unidos, na Europa, seria considerado negro. Acho que para o brasileiro não é difícil. Contando as piadas que a gente conta, levando a 
vida mais leve. Brasileiro tem alegria de viver - jour de vivre (INFORMANTE EXTERNO 5).

O informante interno 1, diante de sua experiência, indicou:

Importante considerar a parte cultural, isso é fundamental, mas também a parte política. Há quantos anos o presidente está no poder? Tem algumas regras (INFORMANTE INTERNO 1).

O informante externo 2, em tom bem-humorado, tentou buscar nos estados brasileiros semelhanças que traduzissem o modo de trabalho dos moçambicanos:

Essa parte cultural, acho que a gente já passou, já conhecemos como é. Acho o povo moçambicano um pouco diferente. $O$ Angolano parece um pouco carioca. $O$ moçambicano parece mais o mineiro. $O$ angolano... eles não trabalham. Falam que estão com problema! Em Angola, em Moçambique não! (INFORMANTE EXTERNO 2).

Um informante interno levantou o desafio das mudanças culturais dentro da própria Empresa. Ele ressaltou que:

Estamos tentando, nesses quatro anos, fazer isso e mudar a cultura difusionista para intercâmbio de conhecimento. No entanto, o modelo ainda está arraigado na mente de muitos pesquisadores. A gente pregava isso (INFORMANTE INTERNO 9).

O informante externo 6 acrescenta, entre as dificuldades, que nem sempre um pesquisador acostumado a trabalhar com um tema específico é capaz de transmitilo. Ele acredita que compreensão e sensibilidade cultural são ainda mais difíceis de alcançar:

Houve um projeto-piloto com a Enap para preparar as instituições
brasileiras. Trabalhar essas questões culturais. Não é simples de se avaliar.
Não dá para as pessoas que atuam no dia-a-dia ter uma formação
adequada. Os pesquisadores são expoentes nos temas e tecnologias que
eles dominam. Não necessariamente têm uma didática para transmitir o
conhecimento da melhor maneira possível. Isso sem nem falar de cultura.
Transmitir o conhecimento não é trivial. Como dizer se essa pessoa é
preparada ou se não é preparada? (INFORMANTE EXTERNO 6).

Segundo os informantes, as diferenças culturais geravam dificuldades no relacionamento interpessoal. Segundo um informante, havia uma diferença no estilo de trabalho:

Está tendo problemas. Pode não ser dito, mas está. A relação entre brasileiros e japoneses está difícil. O brasileiro chega querendo ditar as regras para o japonês e ele não aceita. Como pode estar tudo bem?! (INFORMANTE INTERNO 2)

Outro profissional da Embrapa enfatizou as diferenças culturais: 
Ter reuniões com os parceiros é norma. Os japoneses adoram reunião, visitas de autoridades, visita de Ministério de Relações Exteriores, auditores japoneses... (REUNIÃO INTERNA EM 07 DE AGOSTO DE 2014).

O informante externo 5 tentou indicar algumas diferenças que ele percebeu e que poderiam dificultar as relações:

Entre os moçambicanos e os brasileiros, a diferença já é mortal. Entre japoneses e brasileiros, então. Veja: 1) a pontualidade dos japoneses; 2) a espontaneidade, a informalidade dos brasileiros. São grandes diferenças de comportamento entre brasileiros e japoneses. De maneira geral, os japoneses têm nível de escolaridade mais alto. Pelo menos quem eu conheço. Enviam os sêniores, com certa posição, para as missões. Não conheci o pessoal na ponta em Moçambique, mas os que encontrei no Brasil têm muita experiência. Não quer dizer que não tenha brasileiro de grande qualificação. Existe uma questão sociocultural, econômica. Até o valor que é dado ao conhecimento, no Japão, não é o mesmo que a gente dá aqui (INFORMANTE EXTERNO 5)

Diferente da maioria, o informante interno 12 via as relações entre Brasil e Japão como relações "normais".

Relações normais. Brasil entraria com o expertise e o Japão com o dinheiro. Não houve uma boa integração, mas não houve problema (INFORMANTE INTERNO 12).

Percebe-se que o informante interno 12, em quase todos os seus posicionamentos, diferente dos demais, buscou a neutralidade das respostas. Não se sabe se fez isso para manter o posicionamento institucional ou temendo o impacto interno de suas respostas.

O informante externo 6 fez questão de esclarecer que havia variação nas relações, conforme o nível estratégico ou técnico:

Temos dois níveis para colocar. No nível estratégico de definição do programa sempre houve uma relação de consenso. Isso tem seus momentos. De modo geral, tem uma relação franca, honesta. No nível técnico, tem uma relação que independe dos países, mas é a questão das relações humanas. Situação de dificuldades pontuais, pela dificuldade de se fazer entender ou ter uma postura de ouvir mais o outro lado. Não foram fáceis as relações humanas, que podem ter sido impactantes no próprio trabalho. Essas questões eram tratadas. Tinha uma instância no líder de projeto que eles tentavam resolver. Nem sempre chegavam ao meu nível. Entre nós brasileiros e japoneses, a diferença de visão sobre a organização do trabalho ou da divisão de tarefas não impediu o processo. No ProSavana, essa instância possibilitou reduzir as fricções desse tipo de problema. São vários componentes com várias fases e diferentes organizações envolvidas (INFORMANTE EXTERNO 6).

Segundo o mesmo informante, embora houvesse alguma dificuldade no relacionamento entre os técnicos, não havia desafio relacionado diretamente às 
diferenças culturais entre brasileiros e moçambicanos. Ele ressaltou as diferenças humanas, que podem ocorrer entre pessoas do mesmo país. Por outro lado, ele ressaltou a diferença entre culturas organizacionais. Na sua percepção, havia falhas de gestão que, se fossem conciliadas, poderiam promover uma maior motivação entre os técnicos.

\begin{abstract}
Pessoalmente não percebo diferença e o testemunho das instituições brasileiras é de boa receptividade e boas relações. Às vezes a dificuldade é da cultura institucional, da burocracia do governo de Moçambique. Vejo mais em termos de relações humanas e da instituição. O que ocorre é a postura na ponta. As pessoas não percebem qual é sua relação ao seu papel no Projeto. Não por uma questão cultural, o projeto tenha falhas, mas a parte de transmitir de forma adequada até a ponta do projeto. $O$ funcionário sabe seu papel cotidiano no centro de pesquisa, mas não sabe no programa dar conhecimento de forma sistemática e sistêmica. Até a pessoa se perceber como parte do projeto leva um tempo. Tem uma cultura de não ser proativo ou não poder ser por causa da cultura organizacional. De toda forma, não acho a diferença cultural determinante para 0 desenvolvimento do projeto. Deve-se envolver todos os técnicos de lá. Isso gera motivação. Outra coisa é você entender o todo, como ocorre o ciclo do programa e naquilo que vai resultar o trabalho, o que significa aquele tijolo colocado no processo. É uma questão de gestão dos processos. Em todos os níveis tem limitação de pessoas, desde o governo até um campo em Nampula. Eles têm outras atribuições e participam de outros projetos. Com isso pode parecer que uma atuação insatisfatória é uma negligência, mas ele recebeu uma ordem para fazer outra coisa. Pode parecer apatia, mas recebem informações divergentes de seus superiores. Isso não é exclusivo de Moçambique. Isso se vê isso também no Brasil (INFORMANTE EXTERNO 6).
\end{abstract}

O informante interno 1 também ressaltou que, além das questões culturais, os cooperantes precisam saber lidar com gente:

Pessoas que vão trabalhar fora precisam estar capacitadas em seres humanos. Nesse tipo de experiência, a gente aplica tudo que sabe de gente (INFORMANTE INTERNO 1).

Abaixo serão apresentadas algumas histórias narradas pelos entrevistados, pelo desejo de "partilhar com os outros os insights e a vividez das histórias de vida que se apoderaram de sua própria imaginação" (THOMPSON, 1992, p. 305). Os relatos foram apresentados de forma espontânea pelos entrevistados, ao final das entrevistas, quando questionados se haviam algo além do exposto que gostariam de compartilhar. Todas as respostas reforçam diferenças e choques culturais.

O informante interno 2 surpreendeu-se com o modo de vida, o informante interno 7 e o informante externo 2 com os costumes, e o 12 com os valores.

O informante interno 2 comentou: 
Lá não existe a figura do camponês, do produtor rural como aqui. É uma pessoa que mora no campo (INFORMANTE INTERNO 2).

O informante interno 7 relatou que:

A gente chega no local e então percebe que os costumes são outros. Por exemplo, vimos que eles ficavam com o corpo bastante curvo para utilizarem enxadas de cabo curto. Então, levamos enxadas de cabo longo para facilitar o trabalho, gerar mais conforto. No dia seguinte, quando os encontramos percebemos que haviam cortado os cabos das enxadas. $\mathrm{Na}$ verdade, eles cortaram os cabos para colocá-las em suas costas para facilitar o deslocamento (INFORMANTE INTERNO 7).

O informante externo 2, indignado, ressaltou:

Quem toma conta do campo são as mulheres, os homem fazem a comercialização. A divisão do trabalho não parece justa. É sacrificante. Elas são as principais para irem no campo. No Brasil, a mulher fica em casa ou ajuda esporadicamente no campo (INFORMANTE EXTERNO 2).

O informante interno 12 relatou:

Lá é tão diferente que, por exemplo, se eles virem uma torneira como essa aqui em uma instituição, eles vão lá é pegam. Os equipamentos e materiais são úteis para roubar. Não tinham noção de manutenção. Com os portugueses, eles exportavam. O pessoal tomou a propriedade, mas não continuou plantando. Não tinham o lado econômico. Comeram os rebanhos, consumiram, acabaram sem gerenciamento. Vivem dos recursos naturais, sobrevivem da caça. Lá você não ouve barulho de sapo, de pássaros. Eles voltaram para o início do processo, para os anos 1500 da vida. População não se misturou. Expulsaram os brancos e ficaram os negros. O racismo impera. Muito difícil ver um mulato. Vivem sem previdência e sem planejamento. Tinha que ter alguém preocupado com o futuro. A mulher planta, porque tem um filho nas costas e outro na barriga, por necessidade. Você passa na beira da estrada, tem gente vendendo rato (INFORMANTE INTERNO 12).

O informante interno 11, embora tenha percebido, claramente, as diferenças culturais, ressaltou a proximidade e a afinidade entre brasileiros e moçambicanos:

As diferenças culturais existem, certamente, mas os moçambicanos gostam de trabalhar com os brasileiros. Têm mais proximidade. $O$ chinês é bem diferente. Depois o Brasil é sede do desenvolvimento (INFORMANTE INTERNO 11).

Relacionando a experiência do Prodecer, no Brasil, com a do ProSavana, em Moçambique, um dos cooperantes mencionou:

Houve missões do Brasil, Moçambique e Japão com visita às áreas do Prodecer. Foram contatados grupos, cooperativas e ouviram as comunidades das localidades visitadas. Mesmo depois do Prodecer, na realidade, o nível de produtividade era um sonho. Para os padrões do Brasil era um padrão de excelência. Serviu de motivação para Moçambique. Eles querem independência e soberania alimentar. Esses são temas fortes que 
Moçambique sempre coloca. Reconhecer essas experiências. Por outro lado, Moçambique sempre foi cuidadoso no seu processo interno. O uso da terra, a posse da terra é muito diferente no Brasil. O Corredor de Nacala não é como foi feito aqui. Lá existe uma ocupação completa. Uma questão significativa é o resultado de outras ações de desenvolvimento, ações de ordem logística, as parcerias brasileiras, como a ferrovia são condições que os diferencia (INFORMANTE EXTERNO 6).

Um informante mostrou como conseguia contribuir com as necessidades dos locais, de forma educativa:

Usei meu salário para ajudar as pessoas. Era uma reserva pessoal. Se alguém pedia um dinheiro emprestado, eu emprestava, mas se outra pessoa pedia também, eu dizia para pegar com aquele que havia pedido antes. Dessa forma, eles repassavam o mesmo valor uns para os outros. Além disso, se alguém morresse em uma família, eu dava 40 dólares. É importante ter a família emotivamente envolvida. A minha família também se envolveu com as famílias de lá. Isso faz parte do meu jeito de tratar as pessoas, elas precisam ser valorizadas. A Africa te ensina. O silêncio é seu melhor amigo. Sozinho você escreve coisas que você precisa reler (INFORMANTE INTERNO 1).

\section{Gestão do Projeto: a atuação da $A B C$ e da Embrapa}

Os cooperantes, fossem eles da ABC, da JICA ou da Embrapa, enfatizaram que o planejamento e a comunicação foram um dos quesitos mais negligenciados. Um informante interno assinalou:

A gente tem um pouco de dificuldade, é um ponto para melhorar: comunicar mais as informações. Quando a missão for se encontrar com o moçambicano para entender melhor, deveria ir na mesma época. Cada missão acontece em uma época. ABC tem restrições, dificuldade para trabalhar melhor em conjunto. Fazer um bom planejamento. Brasileiro vai para lá e deixa trabalho aqui. Prioridade aqui e não lá. Tem época da chuva. Difícil combinar. Tem o lado de Moçambique, Japão...para encontrar todo mundo junto é difícil (INFORMANTE EXTERNO 2).

A dificuldade de realizar os encontros presenciais, por cancelamento ou adiamento de missões gerou insatisfação, porque a comunicação não fluía como previsto. Outro informante externo esclareceu:

Não houve preocupação no início do programa com a comunicação. Embora tenha instâncias de comunicação, percebe-se a dificuldade na implementação conjunta. As coisas são vistas como algo que cada um faz sua parte, sem integração. Tem descompasso no nível da relação técnica (INFORMANTE EXTERNO 6).

Um informante externo, em reunião na Embrapa, também apresentou a comunicação como uma falha no processo: 
Dada a dimensão do ProSavana, coincidiu um momento de silêncio do governo moçambicano. O esforço de avanço com a sociedade civil é mais positivo, tem essa interação, mas os movimentos em Maputo criticam. $O$ envolvimento viria em um momento posterior, mas eles não compreendem dessa forma. Os dirigentes dizem que não responderemos de forma isolada, mas iremos tratar, de fato, com quem está lidando com o problema. Uma falha foi não ter preparado a comunicação para diferentes níveis e atores envolvidos. Aqui já tivemos uma sinalização de tratar de forma política a questão do ProSavana. O Brasil não faz só o ProSavana e ele não segue uma linha diferente das demais iniciativas que contam com o apoio de todos. Da mesma forma, o ProSavana busca avançar em seus objetivos. Já estamos trabalhando internamente pra não colocar gasolina na fogueira. Estamos ainda com uma defasagem para apresentação de resultados concretos. O ProSavana virou uma marca muito comentada. A imagem negativa ficou maior que o programa. O lado japonês tem um componente adicional porque tem uma linha de cooperação financeira e ações que não estão circunscritas nas relações técnicas. Tem ações do Ministério da Agricultura, mas como é na região do Corredor, dizem que é o ProSavana. O presidente da República fez apontamentos fora da realidade. Fragilidade do que se coloca. Retomar um mínimo de normalidade (REUNIÃO INTERNA EM 07 DE AGOSTO DE 2014).

Por outro lado, conforme o documento interno "Il Reunião de Coordenação para Início das Atividades Previstas no Primeiro Plano Anual de Trabalho Conjunto $\left(\right.$ Work $\left.\operatorname{Plan}^{29}\right)$," da SRI, é apresentada a intenção de promover um trabalho compartilhado:

Na ocasião foram discutidos e aprovados os seguintes temas:

Plano de Operação Conjunto ( $P O)$ : considerando que os recursos humanos do IIAM são limitados, deverá haver o compartilhamento entre as partes dos planos de envio de especialistas brasileiros e japoneses, para que seja possível a elaboração de um plano único de envio dos especialistas, bem como das capacitações a serem realizadas no Brasil e em Moçambique (EMBRAPA, 2011c, p. 1).

A geração de dados e de informações consolidadas e confiáveis pode reduzir as tensões, responder aos desafios do planejamento e da gestão e até mesmo tornar visível a contribuição não somente do ProSavana, mas da CTPD brasileira. Resultou dos desafios enfrentados a necessidade de maior coordenação para implantar o fluxo de comunicação:

Foi criado um gabinete de coordenação tripartite, que está fisicamente localizado em Maputo. O apelido é ProSavana Headquarter ou ProSavana HQ. A ideia era de ter uma instância capaz de aglutinar os três projetos para questões executivas e técnicas e facilitar o andamento dos projetos, organizar os fluxos de informação e implantar o fluxo de comunicação (INFORMANTE EXTERNO 6).

\footnotetext{
${ }^{29}$ Work Plan: Plano de Trabalho em inglês.
} 
Ainda que tenha sido criado um gabinete de coordenação em Maputo, inclusive pelo desejo dos atores envolvidos em minimizar as frustrações e promover uma boa comunicação, percebe-se que havia uma insatisfação generalizada:

Atuei em um curso de um dos componentes. Sei pouco sobre o Projeto como um todo. Ficamos atendendo demandas. As discussões já tinham ocorrido quando iniciei o trabalho. No ProSavana a distribuição das responsabilidades foi feita na pressão dos prazos. O Chefe tinha a visão do todo, mas eu não recebia (INFORMANTE INTERNO 6).

Ao ser questionado sobre possíveis alternativas, o informante interno 6 desabafou que:

A equipe deveria estar envolvida desde o início para construir o programa
de forma participativa, senão está somente cumprindo uma tarefa. O ponto
fraco é a ausência de uma visão sistêmica. O que acontece no meu nível
deve ter acontecido em todo o processo. Precisa ter começo, meio e fim.
Uma visão holística ajudaria. Isso gera fragilidade do próprio programa. Os
cursos são encomendados sem saber de quem e de onde. A gente não
sabe se é a ABC que está impondo. Você como técnico precisa ter a visão
total. A fragilidade mina todo o programa. Fica à mercê da sorte. Não se
conhece o território, linhas norteadoras, filosofia. É uma conversa de
surdos. É grande a distância entre equipe beneficiária e equipe proponente
(INFORMANTE INTERNO 6).

Embora a $A B C$ tenha sido apontada como vilã no que se refere ao repasse dos recursos, no que tange à comunicação com a $A B C$, um profissional da Embrapa afirmou:

Sempre tinha alguém da $A B C$ acompanhando. Queriam informação. Tivemos apoio total da ABC (INFORMANTE INTERNO 13).

No que se refere à comunicação de pesquisadores e analistas lotados na sede da Empresa com os líderes de projeto em Moçambique, um informante interno ressaltou:

O suporte que tivemos dos brasileiros da Embrapa que estavam lá ajudou bastante. Conheciam muito sobre eles (referindo-se aos moçambicanos). Muitas das interrogações que tínhamos eram respondidas por email. Quando estavam no Brasil faziam a contextualização (INFORMANTE INTERNO 6).

O tema da comunicação foi bastante comentado por vários entrevistados. No entanto, percebe-se que o entendimento do significado de diálogo é diferenciado entre os atores, tendo em vista suas respostas ao longo das entrevistas.

O Informante Externo 5 acrescentou que admira o trabalho e a qualificação dos técnicos da Embrapa, mas lamentou a falta de gestão da cooperação brasileira. 


\begin{abstract}
A Embrapa tem uma massa crítica das melhores do país, com elevado número de doutores e mestres. A proporção da Embrapa de doutores e mestres era das maiores no país. Dentro dessa perspectiva, está fazendo o melhor. Com exceção dessa cartilha, a ABC não sabe gerir o processo. Não existe um sistema equilibrado, correto, estruturado de cooperação no Brasil. Não é porque você tem uma instituição vinculada para atuar nessa área, que você tem uma estrutura. Não é por isso que você sistematizou. Isso não é sistematizar. Para sistematizar, você deve gerar o conhecimento pela apropriação do aprendizado que você em campo está desenvolvendo. Nem tem esse sistema aqui no Brasil. Apropriação para geração de novos conhecimentos, para avaliação dos programas. Não estou falando da Embrapa, mas do sistema de cooperação que não existe e que se existisse deveria ter um papel de produção de conhecimento próprio, sistematização, catalogação de conhecimento próprio que permitisse a avaliação e reavaliação dos programas de cooperação (INFORMANTE EXTERNO 5).
\end{abstract}

Um informante interno, embora tenha percebido os pontos fortes da cooperação, também apontou a necessidade de melhorar a gestão do Projeto, como um todo.

O ponto forte é ter o acordo de cooperação. Isso já é um passo. $O$ conhecimento entre representantes, atores envolvidos vindo da África, indo para lá... De toda forma, falta toda uma sistemática de condução (INFORMANTE INTERNO 6).

Além da preocupação com a comunicação, os cooperantes brasileiros trouxeram a necessidade de aprimorá-la junto aos cooperantes moçambicanos, no sentido de levantar demandas e expectativas e entender o que cada contraparte espera dos atores envolvidos.

O acordo é mais que relações exteriores, envolve cultura, conhecimentos profundos da parte socioeconômica, visão, expectativas. Só essa parte de expectativas, dá uma tese de doutorado (INFORMANTE INTERNO 6).

São 47 unidades e a gente valoriza o trabalho de cada pesquisador. A Embrapa tem uma pluralidade e é importante que seja valorizada a visão de cada um. É preciso considerar também a demanda. Moçambique queria que fosse feito um corredor para produção de soja (INFORMANTE INTERNO 9).

Assim como o informante interno 6 e 9 apontaram a necessidade de levantar as expectativas, para melhor qualificar a demanda, o informante externo 6 ressaltou que entender e estruturar bem a demanda é a própria razão de ser da cooperação:

De modo geral, a razão de ser da cooperação tem um ponto inicial: como entender a necessidade de quem solicita a cooperação. E também articular os recursos e os meios para que essa cooperação seja a mais completa possível. A maneira como a demanda é qualificada e a resposta é estruturada... Tudo isso também passa por um entendimento de um arranjo político do que foi pactuado no princípio. Deve ser permanente atuação de gestão e apoio político para que as condições iniciais do projeto sejam mantidas (INFORMANTE EXTERNO 6). 
Se por um lado, esses informantes concordavam e compreendiam a qualificação de demandas como importante, ainda assim, o informante interno 6 reclamou que essa etapa não era realizada a contento:

Conseguia inferir as necessidades operacionais. Não conheci as pessoas. Nunca estive na África. Como elaborar um curso para uma demanda sem elementos? Precisava de uma scoping mission. Tinha que ter um mínimo de conhecimento do terreno, se você quer estimular um tipo de cooperação participativa com benefício para o beneficiário (INFORMANTE INTERNO 6).

$\mathrm{Na}$ prática, ainda que essa etapa não fosse realizada de forma plenamente satisfatória, segundo o informante interno 11, os resultados foram alcançados:

Fizemos um treinamento grande e foi sucesso absoluto. Muito aplaudido por eles. Começaram 18 e terminaram 22, porque pessoas que estavam de férias ouviram comentários elogiosos e decidiram participar do curso. Não tinha como obrigar as pessoas a irem. Além de tudo, nesses cursos você tem que dar café, comida. A gente não tinha. Ainda assim, todos chegavam antes da hora e ficavam até terminar, mesmo sem água. Cada um levava a garrafinha d'água. Saíram de lá com o projeto de pesquisa elaborado. Pegaram as ideias que eles tinham e apresentaram o projeto elaborado. Foi espetacular vê-los apresentando os projetos. Avançou a carga-horária. A cerimônia de encerramento foi quase às $19 \mathrm{~h}$, tamanho entusiasmo. Depois a $A B C$ cancelou os recursos. Mas até aí a equipe da Embrapa fez trabalho hercúleo. Com o mínimo, fez muita coisa. Mais do que a tecnologia testada, a gente estava querendo compor um time (INFORMANTE INTERNO 11).

Com relação à atuação e a forma de gestão, especificadamente da Embrapa, um informante interno declarou:

A Embrapa tem expertise técnica. É importante, mas não é suficiente. Precisa estar contextualizado e ancorado num programa que envolve questões antropológicas, éticas, socioeconômicas. O próprio estilo de cooperação oscila entre dar o peixe e ensinar a pescar. Gostaria de ter participado das discussões, de ter mais informações, ter visão mais integradora do projeto. É limitada (INFORMANTE INTERNO 6).

O informante interno 13 apresentou seu posicionamento referindo-se à Empresa como um todo.

A Embrapa está sem cliente e sem missão. A missão institucional perdeu o sentido. A Embrapa não faz mais o que está exposto em sua missão. A empresa tem gestores, mas não tem liderança. Um gestor, um chefe de unidade chega e acompanha os projetos dos pesquisadores, mas não tem seu próprio projeto de apoio para a transformação da Empresa. Depois quando é perguntado o que a unidade fez, reúnem-se os trabalhos geridos pelos pesquisadores naquele período e pronto. A Embrapa precisa se transformar. Não pode viver do passado, do discurso da soja no Cerrado, do ILPF, apresentando as mesmas coisas com outras roupagens. Um pesquisador da Embrapa, hoje, não atua nem com $20 \%$ da sua capacidade, porque a música que toca na Empresa é lenta. Se você trocar a música, as pessoas se animam. A questão é que quando você quer mudar a marcha, você não consegue e precisa ficar dirigindo na primeira marcha. Não dá 
para colocar segunda, terceira, quarta, porque esbarra em um sistema que freia. Uma pessoa não pode ser um chefe e dizer que não quer se desgastar na negociação de uma proposta técnica importante. Então é chefe por quê?! Só pelo poder e status?! Foi criado agora o Agropensa e eu acho que é uma boa ferramenta, mas não vai prospectar o futuro da Empresa. É todo um jogo político (INFORMANTE INTERNO 13).

\section{O informante externo 6 levou à questão para uma esfera ampla:}

Percebo que no nível de coordenação não se tem assumido a liderança de forma adequada e isso se replica em instâncias inferiores. Naquilo que foi possível advogar, os principais pontos foram assumidos. Não é uma questão fácil, simples e nem se pode acusar, porque não exerceram as lideranças, de forma plena. Existe dificuldade no entendimento do que é a cooperação em si. O moçambicano sabe se posicionar, sabe se colocar, não abaixam a cabeça para tudo, independentemente do recurso. Isso é importante para que as instâncias não sejam figurativas. Não são manobrados (INFORMANTE EXTERNO 6).

\section{O informante externo 5 considerou:}

A liderança, também, decorre da sua organização. Esse improviso... e a Embrapa, como fica a reboque da $\mathrm{ABC}$, acaba tendo que contar com os japoneses. Aí, vai liderar: quem está pagando ou quem está pedindo ajuda? Suas estratégias vão ficar limitadas. Ass vezes, não é falta de dinheiro é falta de organização. Não digo isso, pela Embrapa, mas pelo lado brasileiro, a falta de um sistema estruturado, por exemplo: com a participação do Congresso Nacional, Comissão de Relações Exteriores do Senado e Câmera, sociedade civil, institutos, fundações, ONGs para a sociedade saber o que está acontecendo. Se fizer uma pesquisa por ano, no Brasil, no mínimo $5 \%$ da população sabe o que é o Prosavana, agora vai lá no Japão... (INFORMANTE EXTERNO 5).

Um informante interno sugeriu:

Entender o espírito, a identidade da Embrapa. Como as pessoas veem a gestão? Como elas veem o macro? Quais são as soluções? É preciso perguntar, enriquecer, refletir sobre o que seria ideal e construir identidades, fortalecer identidades (INFORMANTE INTERNO 1).

Com relação às perspectivas do ProSavana, diante da crise que o assola, um espectro de incertezas o envolve. O informante 11 vê com preocupação a continuidade tanto desse Projeto como de outros que dependem das verbas do Governo:

Quando a Dilma entrou, ela cortou dinheiro do Ministério e cortou os recursos da $A B C$. Isso gerou dificuldade para administrar os poucos recursos em vários países. Acho que a tendência é piorar. No cenário do país com cortes de despesa, não acho que 2015 será melhor que 2014 (INFORMANTE INTERNO 11). 
Tenho baixas perspectivas para 2015 e 2016, em termos de recursos (INFORMANTE EXTERNO 6).

O informante interno 11 lamentou, ao imaginar uma interrupção do Projeto por falta de recursos, e informou que os técnicos em Moçambique apoiavam as iniciativas da Embrapa:

Eles estão ansiosos e com medo que por falta de recurso não se possa manter o Projeto. Eles começaram a fazer boletins e apresentar resultados, mostrar para a sociedade que eles estavam produzindo alguma coisa (INFORMANTE INTERNO 11).

Ao ser questionado em reunião sobre a possibilidade de suspender a atuação da Embrapa no Projeto, um técnico respondeu:

A responsabilidade técnica pesa muito. Apesar das limitações, a gente faz 0 trabalho com muito orgulho. Isso vai do gosto dos profissionais (REUNIÃO INTERNA, EM 06 DE AGOSTO DE 2014).

Um informante externo recomendou:

Não gostaria de fazer considerações políticas, mas acho que se a Embrapa se mantiver fiel a sua agenda de pesquisa desligada de interesses políticos, ideológicos e comerciais, acho que é um bom princípio (INFORMANTE EXTERNO 1).

De modo geral, os entrevistados apresentaram baixas perspectivas quanto às possibilidades reais da continuidade do Projeto. Eles acreditam que a situação de crise no país deve piorar em 2015 e que na ausência dos recursos, o Projeto será finalizado com pouco êxito.

5.2.2 A experiência de cooperação da Embrapa no projeto ProSavana frente às oportunidades apresentadas

Além dos desafios, descritos na subseção anterior, os entrevistados identificaram algumas oportunidades e pontos fortes, que serão apresentados a seguir, a fim de ampliar a visão sobre a problemática vivenciada na CTPD, com particular referência ao Projeto ProSavana-PI. 


\section{Contribuir para o desenvolvimento agrícola}

Independente das motivações políticas, o discurso técnico traz fortemente o componente ideológico, a vontade de contribuir para o desenvolvimento da agricultura em Moçambique. Um informante interno indicou:

A razão do projeto existir foi o objetivo. Esse é o principal ponto forte. Apoiar - IIAM em termos agrícolas. Eles fazem uma agricultura de subsistência. Queriam trabalhar com alta tecnologia, porque a agricultura do país não supria o país. Só em milho são autossuficientes. Fizeram uma revolução e os portugueses foram expulsos. Ficaram somente os nativos. Essa população não detinha conhecimento e produziram como sabiam. A Embrapa se desenvolveu pelas demandas que tinham. Lá (referindo-se à instituição de pesquisa) não tem demanda. Estão em um nível de desenvolvimento baixo. Precisava ter base produtiva. A área tem viabilidade técnica, tem logística, porto, linha férrea, mais próxima da China. Estava todo mundo de acordo. Esse grupo geraria uma demanda para o IIAM: soja, milho, algodão, ou seja, algumas commodities. Moçambique não tem indústria. O país não produz proteína animal. Não tem produtor rural, como no Brasil. Tem quem mora no campo. Não existe comércio. Não existe mercado (INFORMANTE INTERNO 12).

Os relatos dos cooperantes "embrapianos" são cheios de orgulho e paixão por aquilo que conseguiram levar aos colegas do IIAM. Eles queriam homenagear os parceiros da Embrapa, citar seus nomes e sua atuação abnegada:

Essa história do treinamento surpreendeu pelo conteúdo, didática, entusiasmo [...] Não eram acostumados (os moçambicanos) a verem experimentos com sentido lógico, com rigor científico. Viram PhD esparramando calcária, todo sujo. É uma lição que eles nunca vão esquecer. Trabalho abnegado, anônimo, sem ter necessariamente 0 reconhecimento formal. $O$ treinamento e 0 trabalho dos pesquisadores quem fez foi o Cecat, a Embrapa Trigo, com o Denardin ${ }^{30}$. O Henoque Silva ${ }^{31}$ fez um trabalho de abnegação, fazendo tudo na mão. Uma equipe que efetivamente deixou um legado e deu uma envernizada na imagem do Brasil (INFORMANTE INTERNO 11).

Um informante externo com um vasto sorriso elogiou a competência da Embrapa:

Uma instituição com mais de 2000 com doutorado e pós- doutorado. Todo mundo vê a Embrapa como top. São 47 unidades. É um orgulho trabalhar com. Embrapa. O conhecimento dos pesquisadores [...]. Fomos para Guiné Bissau. Eu que sou leigo de agricultura, eles dão segurança pra gente. $O$ Edson conhece vários países. Viu que estava usando semente inadequada para o solo e perguntou: De onde vêm as sementes? Da Europa. Semente inadequada para 0 sol quente, solo seco. Semente inadequada (INFORMANTE EXTERNO 2).

\footnotetext{
${ }^{30}$ José Eloir Denardin: pesquisador da Embrapa Trigo.

${ }^{31}$ Henoque Ribeiro da Silva: pesquisador da Secretaria de Relações Internacionais.
} 


\title{
O aprendizado institucional e individual
}

Não somente os ganhos financeiros foram indicados pelos entrevistados. $\mathrm{Na}$ prática, foram indicados ganhos institucionais e individuais, até mesmo diante da complexidade da iniciativa. $O$ informante externo 6 apontou alguns deles:

A concepção de um programa tão amplo e complexo poderia gerar questões igualmente complexas, mas ter havido um envolvimento entre os países, ligado ao plano e a construção de um mecanismo de coordenação foi muito efetivo. A condição de articular e definir dentro do programa, a busca por instrumentação e metodologias... existem muitas lições aprendidas que já são utilizadas em outras parcerias (INFORMANTE EXTERNO 6).

Um informante interno apontou o ganho individual do líder de projeto:

É preciso pensar como a pessoa que vai coordenar o projeto está se vendo. Há algo mais que o valor do pagamento. Tem um ganho em oportunidade (INFORMANTE INTERNO 1).

Foi apresentada oportunidade para avanços além do ProSavana:

O Brasil tem um leque muito variado e pesquisas claras, e isso está mais do que dito. Vários atores potencialmente são aliados parceiros interessantes para a África (INFORMANTE EXTERNO 1).

Os cooperantes indicaram, a partir das suas vivências, pontos que consideraram importantes e que, segundo eles, deveriam ser repetidos a fim de garantir a efetividade dos projetos de CTPD:

\begin{abstract}
Não carregar uma carga pessoal, estar bem resolvido consigo mesmo e não em busca de uma fuga para questões pessoais. Por exemplo, uma pessoa que se separa e quer sair do país para se afastar da situação. A comunicação é importante. Se tiverem outro idioma, é importante estudar a língua. Conhecer os países e saber como vai se inserir. Para sair, tem que ter lido sobre cultura. Tem três coisas que considero fundamentais: 1) Não vai reinventar a roda; 2) Saber ouvir; 3) Tomar dois copos de humildade por dia. Precisa ser extremamente observador (INFORMANTE INTERNO 1).

Fundamental ir motivado. Notadamente o lado do parceiro. É difícil por causa das condições de trabalho. No patamar mais alto precisa saber motivar a equipe local e entender o projeto como algo importante. Ter equipe motivada. Ter retaguarda institucional que suporte 0 desenvolvimento do projeto tanto do lado da Embrapa como do lado dos parceiros (INFORMANTE INTERNO 11).
\end{abstract}

Outros levantaram questões institucionais e políticas:

A fala publicitária diz que a Embrapa capacitou x produtores rurais, mas ao verificar no detalhe, os presentes são os gestores e que não têm em suas atribuições a multiplicação. É preciso ter foco (INFORMANTE INTERNO 4). 
Os moçambicanos querem ter uma instituição de pesquisa nos moldes da Embrapa. Esperam que a Embrapa vai transferir suas tecnologias para 0 IIAM. O modelo não está pronto. Aí o paradoxo do protagonismo: você chega lá e monta para eles ou você ajuda e eles montam? Isso vai definir o estilo da cooperação. É preciso saber como vamos atuar! (INFORMANTE INTERNO 6).

Ter uma relação mais próxima com a sociedade civil, com os agricultores. Isso funcionou bem no Cotton 4 e falhou no ProSavana (INFORMANTE INTERNO 13).

É possível ter coerência entre discurso e prática (INFORMANTE INTERNO 3)

\section{O informante externo 1 e 6 e o informante interno 11 sugeriram formas de} reconhecimento ao trabalho dos cooperantes pela Embrapa:

Poderiam ampliar os estímulos financeiros. Muitos pesquisadores dizem que perdem financeira e emocionalmente. Noto que o que os motivam é o interesse pessoal em descobrir, em ter uma aventura, em conhecer a África. Motiva a ida por períodos curtos, mas ninguém quer ficar por muito tempo. Lá é visto como um mundo muito hostil. Há curiosidade, mas não há fascínio para ficar lá. Por isso deveria ter um incentivo financeiro ou uma carreira, como dizia Farani ${ }^{32}$, de pesquisadores de desenvolvimento. Acho que há um problema em criar estruturas locais e carreira (sic.). Um dos aspectos positivos é ter o intercâmbio direto e partilhar um pouco do trabalho entre experiência no Brasil e fora. Por outro lado, se tiver uma carreira, perde essa relação. Poderia virar como políticos de profissão. Tem aspectos virtuosos e limitações. Podem virar muito tecnicistas e não considerar os problemas culturais (INFORMANTE EXTERNO 1).

Pode ser positivo o envolvimento com outras instituições, além da Embrapa. Além disso, poderia fazer um processo que uma vez que se alocasse um pesquisador, passasse a gerar uma pontuação em seu desenvolvimento interno, reconhecimento formal do trabalho. Incorporar produtividade em projeto de cooperação internacional (INFORMANTE EXTERNO 6)

Estimular o trabalho e dar nome dos profissionais na publicação. Conta para conseguir bolsa de pesquisa (INFORMANTE INTERNO 11).

\footnotetext{
${ }^{32}$ Ministro Marco Farani - foi diretor da Agência Brasileira de Cooperação (ABC)
} 


\section{ANÁLISES DOS DISCURSOS}

Neste capítulo, é analisado o discurso institucional da Embrapa e o discurso dos cooperantes, sejam eles técnicos da Embrapa, da $A B C$, da JICA ou especialistas acadêmicos. A partir de eventos, documentos públicos e internos, falas e posturas em reuniões, entrevistas e conversas informais - buscou-se mapear conexões entre os atores sociais ou grupos, recompor esse conjunto de discursos, compreender sua atuação no ProSavana e apresentar argumentos para ponderações.

As entrevistas realizadas com atores-chave relacionados ao ProSavana proporcionaram a coleta de informações e percepções dos entrevistados, que serão analisadas, conjuntamente, e em comparação com alguns estudos bibliográficos.

A apresentação dos discursos de forma sistematizada, dividindo por categorias os informantes e por temáticas relativas aos desafios e as oportunidades, objetivou identificar a complexidade da questão central objeto desta análise. As questões são transversais, entrelaçam-se, formam redes. Impossível dar o encadeamento perfeito para vivências e categorizá-las em blocos únicos. Um trecho da narrativa poderia estar em mais de um local. De toda forma, ao rever pontos sendo tratados em diferentes momentos, é fortalecida a percepção sobre as problemáticas comuns apontadas de modo individual, sem que um entrevistado soubesse o que foi indicado por outro.

No tocante aos discursos institucionais, percebe-se um longo distanciamento entre discursos verbais e documentos da Empresa. Os textos oficiais, alguns já defasados, não traduzem de forma fiel o pensamento de seus dirigentes. Nota-se, a partir dos textos escritos e das narrativas institucionais, que a Embrapa ainda caminha em direção a uma abordagem mais moderna de atuação tanto nas relações nacionais como naquelas com Moçambique. Embora o discurso atual indique 0 desejo de se trabalhar com intercâmbio de conhecimentos e construção coletiva do conhecimento, os documentos exprimem uma atuação difusionista.

Segundo o Estatuto da Embrapa existe uma preocupação em transferir as tecnologias da Empresa e incentivar os talentos nacionais. No entanto, o documento não menciona o intercâmbio de conhecimento, a busca de soluções compartilhadas e o apoio ao desenvolvimento das capacidades profissionais de técnicos de nações em desenvolvimento. Do mesmo modo, no V Plano Diretor da Embrapa, embora 
seja abordado o termo parcerias, nada é dito sobre os benefícios para os parceiros e/ou recipiendários da CTPD brasileira, mas somente para a Embrapa.

Sobre a cooperação com a África, por outro lado, os documentos da Embrapa apresentam termos que refletem uma abordagem diferenciada, tais como: "compartilhar de conhecimentos e experiências", "cooperação" e "irmandade". Termos esses alinhados com o discurso institucional do MRE: "cooperação", "solidariedade", "parceria" e "horizontalidade".

Quanto à cooperação, seja ela no âmbito nacional ou internacional, no V Plano Diretor da Embrapa é enfatizada a valorização de "atitudes cooperativas", "construção de alianças institucionais" e a "atuação em redes" para "compartilhar competências". Nesse aspecto, o Prosavana é um exemplo de projeto de cooperação triangular, formado por alianças institucionais, assim como grande parte dos projetos nacionais e internacionais da Embrapa.

Embora o PDE apresente os valores institucionais e deixe claro sua "interação com a sociedade", sabe-se por meio das entrevistas com os cooperantes, sejam eles informantes internos ou externos, que no caso da cooperação internacional não é feito um trabalho adequado de prospecção de demanda e tampouco de avaliação do impacto dos trabalhos. Até mesmo o documento Visão 2014-2034 ressalta a necessidade de "ampliar a sinergia entre as ciências cognitivas, sociais e econômicas para tratar questões da dimensão humana e das relações com a sociedade." Algumas iniciativas já estão sendo encaminhadas pelo DTT, assim como a elaboração do marco lógico que ensaia uma abordagem de trabalho com as comunidades rurais e propõe um repensar do modelo difusionista.

Conseguir gerenciar de forma eficiente e efetiva as relações entre indivíduos, comunidades e instituições de diferentes países tem se tornado um dos maiores desafios enfrentados pela Embrapa para operacionalizar suas iniciativas de CTPD. Embora, os técnicos e pesquisadores da Embrapa "participem pessoalmente nos projetos de cooperação, adaptando os seus conhecimentos e tecnologias desenvolvidos no contexto agropecuário brasileiro para os países beneficiários" (CABRAL, 2005, p. 13), enfrentam inúmeros desafios no projeto ProSavana.

Em relação ao desafio "decisões governamentais: o corte de recursos do ProSavana", o sentimento compartilhado pelos entrevistados confirma a preocupação com a dependência de políticas de governo para dar os encaminhamentos necessários para os projetos de cooperação técnica. No 
planejamento de um projeto de longo prazo, é necessário verificar que o orçamento seja adequado para todas suas fases e, por parte do Governo Federal, na figura da $\mathrm{ABC}$, é preciso manter o comprometimento com o desembolso programado para seus avanços.

Os cooperantes justificaram outras dificuldades enfrentadas junto à $A B C$, diante da transitoriedade de seus colaboradores, da deficiência crônica de instrumentos jurídicos e da insuficiência de recursos próprios (PUENTE, 2010). Enquanto, atualmente, para quase todas as agências de cooperação para o desenvolvimento, principalmente nos países desenvolvidos, o tema da accountability, referente à prestação de contas, responsabilização e transparência tem importância tanto na estrutura como no processo de cooperação (PUENTE, 2010; BARROS, 2007), no Brasil, é, ainda, um processo institucionalmente fragmentado.

Embora um informante externo tenha demonstrado compreensão quanto aos cortes de recursos da $A B C$, entendendo que as crises econômicas podem afetar os investimentos de qualquer país, ele entendeu que o efeito desses cortes gerou a necessidade de ampliar o comprometimento e exigiu até sacrifício do corpo-técnico da Embrapa. Os técnicos, principalmente os líderes de projetos, envolveram-se afetivamente com o Projeto e buscaram alternativas das mais variadas a fim de atender da melhor maneira possível às necessidades do Projeto. Ainda que constrangidos dentro de uma parceria na qual a Embrapa não contava com os recursos apropriados para realizar seu trabalho, os técnicos passaram a utilizar de seus próprios bens materiais a fim de apoiar os projetos de cooperação. De todo modo, não foi apenas por causa de cortes orçamentários que foram suspensas algumas ações no ProSavana. As diferentes demandas e prioridades indicadas por uma ou outra gestão interna na Empresa, e que foram interpretadas e comunicadas principalmente pela SRI, também direcionaram ou reduziram os esforços para um ou outro componente ou até outro projeto de CTPD.

É preciso reconhecer que no primeiro ano do Projeto ProSavana-PI os recursos foram disponibilizados pela $A B C$, porém cabia à Embrapa a gestão dos recursos e do cronograma executivo do projeto. Quando foi preciso desenvolver uma metodologia para o gerenciamento de riscos, algumas incertezas e ameaças externas não foram prospectadas. A ausência de um planejamento financeiro e legal 
aprofundado sobrecarregou a execução, deixando a cargo dos participantes um trabalho exaustivo.

Normalmente, nos projetos de cooperação trilateral realizados com o Brasil, 0 país desenvolvido, no caso o Japão, disponibiliza um aporte e o Brasil oferece sua contrapartida com os conhecimentos tecnológicos e o expertise dos técnicos em agricultura. No caso do ProSavana, rearranjos orçamentários foram discutidos ao longo do Projeto e o Japão assumiu desembolsos não-programados. No entanto, embora o trabalho sacrificante que vem sendo realizado, seja por preocupações com o vírus ebola ou por falta de entrosamento interno de alguns participantes, o malestar entre as contrapartes tem se manifestado com argumentos que vão além dos desgastes causados pelo corte de recursos.

Em relação ao desafio "conflitos internos e jogos de poder", a desconsideração das relações de poder que atravessam a cultura, quando levada às últimas consequências, justificaria a admissão da inferioridade de algumas culturas ante outras. Por outro lado, as tentativas de "assimilação", apontariam para o caráter antropofágico da cultura dominante. Ter atitude "segregacionista", em resposta a um quadro de desestabilização econômica, poderia promover a rearticulação de procedimentos xenófobos (LOMBARDO; VALENTE, no prelo).

Quando são mascaradas as relações de poder e dominação entre os grupos em contato, a percepção de seu caráter contraditório é nula. No plano discursivo, reivindica-se esta análise mais abrangente da questão, sem que isso consiga influenciar as práticas levadas a cabo. Entretanto, tal situação de discordância entre discurso e prática pode ser explicada pela lógica societária em que ambas as instâncias estão mergulhadas: histórica e presentemente informada, em escala global, pelo capitalismo que ganha contornos singulares em cada país, tornando mais exigente a busca de soluções (VALENTE, 2003; LOMBARDO; VALENTE, no prelo).

O camaronense Achille Mbembe, pesquisador em história e política, aponta alguns momentos históricos como a escravidão, a colonização e o apartheid como os maiores causadores dos danos psíquicos dos africanos e, por outro lado do desejo em conquistar sua soberania.

A escravidão, a colonização e o apartheid são considerados não só como tendo aprisionado o sujeito africano na humilhação, no desenraizamento e no sofrimento indizível, mas também em uma zona de não-ser e de morte social caracterizada pela negação da dignidade, pelo profundo dano 
psíquico e pelos tormentos do exílio. Em todos os três casos, supõe-se que os elementos fundamentais da escravidão, da colonização e do apartheid são fatores que servem para unificar o desejo africano de se conhecer a si mesmo, de reconquistar seu destino (soberania) e de pertencer a si mesmo no mundo (autonomia) (MBEMBE, 2001, p. 174).

A CTPD conduz a integração de povos e unifica as forças pela diversidade entre países parceiros. Sua ameaça, porém, pode estar em ignorar a fragilidade nas relações, advindas de um ambiente geográfico e contexto sociocultural distinto. $\mathrm{O}$ contato intercultural entre Brasil, Japão e Moçambique, por meio de acordos e iniciativas de aproximação, pode mascarar as tensões, fraturas, exposições acarretadas por uma relação assimétrica e de dominação. É preciso abarcar a complexidade dos contrastes vividos por cada ator. Ao adquirir as competências necessárias para um relacionamento com diferentes povos, sejam elas comunicativas, de ampliação de percepção de mundo, flexibilidade cognitiva, empatia, humildade e hospitalidade, espera-se tornar possível o diálogo intercultural. Para isso, prescinde o fortalecimento da autonomia não somente de um, mas de todos os participantes (UNESCO, 2009).

Uma empresa do porte e importância da Embrapa não pode nem deve perseguir desenvolvimento e progresso apenas em termos puramente tecnológicos. Seria necessário, periodicamente, contrastar os dados dos projetos com a experiência vivida pelos cooperantes em Moçambique, estendendo-se para os demais países. Por ora, os dados trazidos impõem que outras indagações sejam feitas e exigem estudos sistemáticos de como o discurso bastante linear da cooperação internacional - e da cooperação técnica em particular - é operacionalizado na prática; afinal, a cooperação também é marcada pela contradição, por conflitos de natureza diversa e por vários tipos de impasses.

Ainda que na CTPD existam conflitos, tensões e disputas, motivações políticas e jogos de poder (KEOHANE, 1984; SILVA; 2007; MILANI, 2014), deve-se esperar sua ação preventiva em busca de manter a coerência com seu próprio modelo. Modelo esse que, ao respeitar os contextos sociais, culturais e institucionais vigentes entre os recipiendários e ao levantar e atender suas demandas, busca assegurar a horizontalidade possível na relação (PUENTE, 2010).

A efetividade da cooperação internacional depende da contribuição de seus projetos para o alcance de melhores condições institucionais, humanas $\mathrm{e}$ socioeconômicas dos países recipiendários (PUENTE, 2010). A resposta e o 
respaldo da sociedade legitimam e fortalecem as propostas negociadas na instância intergovernamental. As organizações não governamentais têm sido atores muito importantes nas relações de CTPD. Elas exercem pressão, fazem denúncias, organizam campanhas, levantam suas bandeiras de luta política, defendem os métodos participativos de atuação e buscam sua inclusão nas decisões políticas. Ainda que os projetos de cooperação técnica em agricultura no continente africano possam ter atingido bons resultados sem a aplicação de uma abordagem participativa junto à sociedade local, desconsiderar a importância da inclusão de novos atores poderia comprometer o alcance dos resultados desejados.

Fica claro que a cooperação brasileira, embora suas aparentes boas intenções, não soube antecipar as potenciais divergências que poderiam ocorrer com 0 envolvimento de diferentes atores, além dos governos. Desse modo, várias ações foram definidas ao improviso. Portanto, torna-se cada vez mais necessário ter uma atuação proativa, capaz de antecipar os desafios.

No tocante ao "desconhecimento sobre a cultura dos países parceiros", ficou claro por meio da análise das entrevistas que houve uma preocupação em conhecer as demandas do governo de Moçambique, do IIAM e até mesmo das ONGs locais que atuam com desenvolvimento rural. Por outro lado, os próprios cooperantes explicitaram a fragilidade da sua atuação. Seja por falta de tempo ou conhecimento apropriado sobre cultura, a expectativa inicial era de fácil replicação do modelo brasileiro de transferência de tecnologia. No entanto, foi percebido pelos entrevistados que as questões socioculturais eram fundamentais para o sucesso do Projeto.

A preocupação com as diferenças culturais em estudos acadêmicos, desde 0 século passado, é expressão diversificada da tentativa de compreender os mecanismos explícitos e implícitos que conformam a tendência à globalização inerente ao capitalismo. Em momentos de crise têm se desencadeado manifestações reativamente heterogêneas no campo político-cultural. Assim como nas experiências consolidadas de construção dos blocos econômicos no mundo, a cooperação internacional também pressupõe o desenvolvimento de certo nível de homogeneidade a ser construída entre países parceiros. Entretanto, esse movimento pode desencadear a reivindicação da diferença ou de identidades específicas que se contrapõe e que reage à homogeneização (LOMBARDO; VALENTE, no prelo). 
A forma como instituições lidam umas com as outras pode indicar vantagem competitiva e elevar a efetividade de suas parcerias. Assim como uma interação insensível à cultura de cada parceiro pode gerar desgastes. A base das boas relações seria compreender as premissas e as expectativas sobre como as pessoas pensam e agem (TROMPENAARS, 1996).

$\mathrm{Na}$ perspectiva intercultural, não são propriamente os traços biológicos ou características naturais; as tradições culturais ou os hábitos internalizados e cristalizados que estão em jogo; mas os significados construídos sobre as diferenças. Desta forma, torna-se possível criar interstícios epistemológicos através dos quais podemos entrar num processo de negociação cultural, sem impor explícita ou implicitamente os nossos códigos culturais aos outros, característica básica da racionalidade colonizadora. Maneiras simplistas, racionalistas ou anti-relativistas de definir a identidade moçambicana, desconsideram o contexto histórico global no qual as particularidades estão mergulhadas; ao invés de compreender suas singularidades e compará-las com outras particularidades existentes, inviabilizam sua própria compreensão (VALENTE, 2006).

A diversidade cultural tornou-se uma questão social importante. Vinculada à maior diversidade dos códigos sociais e perspectivas que operam no interior das sociedades e entre estas, os estados nem sempre encontram as respostas apropriadas, nem logram colocar a diversidade cultural ao serviço do bem comum (UNESCO, 2009).

Ainda que a Embrapa, em seu discurso formal e institucional em suas publicações, afirme interagir permanentemente com a sociedade, suas práticas parecem não contemplar, em profundidade, as questões socioculturais próprias dos países beneficiários da cooperação. Ainda não existem, institucionalmente, metodologias e dinâmicas específicas para gerenciar as relações interculturais associadas com a transferência e a adaptação de tais conhecimentos e tecnologias. Nota-se o empenho e a busca por uma transformação, mas a própria cultura organizacional impede que sejam efetivas as relações interculturais. Conforme apontam os resultados das entrevistas, o sucesso dos projetos acaba por depender das características pessoais de cada líder e da equipe técnica envolvida.

No entanto, verifica-se que a Embrapa reflete uma fragilidade da própria cooperação técnica brasileira. Até mesmo a Escola Nacional de Administração Pública (ENAP) encontra dificuldade em recrutar professores que entendam de 
cooperação internacional e de cultura. Nesse sentido, para melhor atuar com cooperação técnica internacional, será necessário ampliar a sensibilização para que se contratem para a Embrapa mais profissionais com conhecimentos e vivências em antropologia, sociologia e outras áreas afins. Dessa maneira, a equipe que atua com cooperação técnica internacional poderá se familiarizar com abordagens e metodologias específicas que apoiem o diálogo intercultural. Será necessário que o Departamento de Gestão de Pessoas (DGP), junto às áreas que atuam em projetos de CTPD, busquem cursos, oficinas coletivas e estimulem estudos individuais com esses temas. A SRI, em parceria com o DGP, poderia mapear competências nessas áreas que estejam nas unidades centrais e descentralizadas da Empresa, a fim de criar uma rede para intercâmbio de experiências exitosas tanto nacionais como internacionais, especialmente no que tange ao trabalho com as ONGs e comunidades rurais. A Embrapa, como parte do governo brasileiro, o Itamaraty e a $A B C$ podem, ainda que momentaneamente, incluir nos projetos, consultores que possam apoiar as instituições que representam o Brasil no exterior, por meio de diferentes projetos de CTPD.

As diferenças culturais podem afetar as relações e fazer com que as pessoas não percebam suas afinidades como seres humanos, ampliando as possibilidades de conflito. O desafio consiste em clarificar que, se bem trabalhada, a diversidade pode ser benéfica para a ação da comunidade internacional (UNESCO, 2009). Sob essa perspectiva, prever, planejar e antecipar as características culturais de outro país, antes de se estabelecer uma relação concreta, diminui a probabilidade de geração de conflitos e minimiza insucessos (LOMBARDO, 2012).

As respostas dos entrevistados diretamente envolvidos com a implementação do projeto, sejam informantes internos ou externos, indicam que eles enfrentaram dificuldades de ordem cultural ou humana na solução de problemas. Essas dificuldades estavam relacionadas com estilos, valores, crenças, que refletiam no comportamento entre brasileiros, moçambicanos e japoneses. Nota-se, ainda, que os informantes, ao relatar suas experiências, permitiram que viessem à tona novas reflexões. O informante externo 6, por exemplo, depois de ter comentado sobre as dificuldades da cultura organizacional moçambicana pareceu ter se dado conta que a hierarquização, a verticalização do trabalho e o serviço prestado a mais de um superior hierárquico também ocorrem no Brasil. As instituições parceiras no Projeto têm a hierarquização como um traço comum em suas culturas organizacionais. 
Obviamente que uma preocupação com as relações interpessoais é algo já esperado nas relações entre governos e instituições. Certamente para que as pessoas vivam e trabalhem em um mesmo espaço é necessário que compartilhem valores e regras comuns. No entanto, assim como as especificidades culturais podem ocorrer dentro uma esfera organizacional, até mesmo interdepartamental, seu impacto é ainda mais amplo nas relações internacionais. O informante externo 6 percebeu as diferenças entre culturas organizacionais, mas cabe destacar que as culturas nacionais também se diferenciam entre elas e exigem de quem busca essas interações globais uma postura que reflita essa preocupação.

O informante externo 5 trouxe elementos que apontam para essa diversidade. Ainda que o Brasil e Moçambique tenham vivenciado a colonização portuguesa, o contexto histórico foi diverso. Moçambique obteve sua independência somente em 1975. Sofreu e perdeu milhões de habitantes em uma guerra civil que durou aproximadamente 20 anos, entre as décadas de 1970 e 1990. O Índice de Desenvolvimento Humano (IDH) é um dos mais baixos do mundo e o analfabetismo atinge mais da metade da população. Não há proximidade com a história do Japão.

No ProSavana, as negociações aconteciam em português brasileiro, português moçambicano, japonês e inglês. Os costumes também se diferenciavam. Os moçambicanos, principalmente os islâmicos, faziam pausas do trabalho para suas orações. Os japoneses foram reconhecidos por sua disciplina, capacidade de inovação, foco em alta performance profissional. São visões de mundo distintas que se expressam em comportamentos. Tais características incomodavam, muitas vezes, o cooperante brasileiro, conforme foi explanado em diversos trechos das entrevistas realizadas.

As "negociações", especificamente no ProSavana, podem cessar a qualquer momento ou podem terminar dentro do tempo previsto. No entanto, os diálogos na cooperação sul-sul continuam e há perspectiva que ainda caminharão por alguns anos. Será necessário buscar conhecer melhor Moçambique, compreender sua história, reduzir a dicotomia superior-inferior e apresentar novos paradigmas que incluam o cuidado com a dimensão sociocultural. Será preciso construir unidade na diversidade, enriquecimento mútuo a partir das diferenças, que não são somente humanas, mas culturais.

Enquanto os desafios orçamentários impactaram fortemente na atuação da equipe técnica, a vivência em Moçambique não frustrou suas expectativas. Ao 
analisar suas narrativas, ficou aparente o interesse dos técnicos em conhecer as histórias locais, traduzir sua própria cultura e reinterpretar aquilo que ouviram sobre o país para poder adaptar-se àquela sua nova moradia. Foi um processo difícil, mas satisfatório. Nesse ambiente de significados e traduções, os cooperantes vivenciaram suas emoções, seu isolamento da pátria, da família, atravessando um universo de ausências. Suas motivações internas, em algum momento, tornaram-se maiores que as financeiras. A transmissão do conhecimento ocorreu, enquanto cada um aprendia, não tanto sobre tecnologia e ciência, quanto sobre as culturas locais.

As histórias orais devolvem as vivências às pessoas em suas próprias palavras, que ao revê-las ajudam a construir seus futuros (THOMPSON, 1992).

Cada entrevistado expôs em sua narrativa aquilo que lhe chamou atenção. 0 tempo e o espaço já não eram mais os mesmos. Ainda que suas visões e percepções sejam destoantes, cada um apresentou seu próprio modo de ver aquela realidade. A questão feita pela autora não era orientadora. Os entrevistados foram estimulados a narrar algo que se recordavam e que consideraram importante na sua experiência no ProSavana. De modo geral, a imagem que thes veio à tona ressaltava o componente cultural, no qual está centrado o argumento dessa dissertação.

Em relação ao desafio "gestão do Projeto: a atuação da ABC e da Embrapa", conforme demonstra a revisão de documentos internos e as entrevistas dos informantes, cabe destacar que ainda existe uma grande lacuna entre as estratégias definidas no papel e sua implementação na prática. O sucesso de todos esses projetos, e não apenas do Prosavana, depende muito da gestão, do modelo de liderança adotado e do comprometimento pessoal de cada ator envolvido no intercâmbio de conhecimento e experiências.

A gestão em diferentes esferas, desde a política até a coordenação dos projetos demonstrou-se frágil ou deficitária. Diferentes entrevistados criticaram as falhas de comunicação nos processos de cooperação, demonstrando que a carência de informação não era uma crítica isolada dos camponeses moçambicanos. Foi ressaltada a necessidade de melhor comunicação e troca de informações entre os parceiros. Essa fragilidade tomava um contorno ainda maior, porque conforme os entrevistados, a comunicação era ineficiente ou inexistente em vários níveis, ampliando a complexidade na gestão do Projeto. Ficou claro que ao longo da implementação do Projeto houve um esforço para solucionar os problemas 
relacionados a essa questão. Foi, inclusive, criado o gabinete ProSavana Headquarter ou ProSavana HQ. No entanto, um maior debate entre cooperantes e a definição de boas práticas, levando em consideração às especificidades de cada país, poderia evitar uma gestão de reparos e possibilitar a prospecção e um planejamento mais acertado.

Levantar demandas e expectativas faz parte do modelo difundido pelo Brasil na CTPD, e é fundamental para estabelecer um verdadeiro intercâmbio de conhecimentos. Os entrevistados apontaram algumas alternativas: " $A$ equipe deveria estar envolvida desde o início para construir o programa de forma participativa, senão está somente cumprindo uma tarefa"; "gerar o conhecimento pela apropriação do aprendizado que você em campo está desenvolvendo"; "desenvolver um sistema estruturado de cooperação com papel de produção de conhecimento próprio, sistematização, catalogação de conhecimento que permitisse a avaliação e reavaliação dos programas de cooperação". Nota-se que, embora os princípios de CTPD estejam embasados em uma atuação sob demanda, na prática o diálogo ainda não é efetivo. Fica o silêncio no ar, deixando os profissionais de diferentes níveis alheios seja às determinações políticas ou institucionais.

Fica claro, principalmente nas vozes dos informantes internos e, principalmente naquela do informante interno 13, que a Embrapa, não somente no âmbito internacional, mas de modo geral, atravessa uma crise de gestão. A Empresa é composta por uma maioria de engenheiros agrônomos, e não requer para as funções de chefia nenhuma formação em administração de empresas, desenvolvimento organizacional e gestão de projetos. Muitas das vezes, em decorrência disso, ocorrem equívocos na interpretação de quais competências são necessárias para ser um gestor de projetos que atue com CTPD. Muitas vezes, a Empresa perde um talento na pesquisa quando acredita que o competente pesquisador será também um bom gestor ou líder. É papel da gestão empreender ações com foco em atingir os resultados desejados, estabelecer as melhores práticas e condições de trabalho possíveis, administrar os recursos, as ferramentas disponíveis, bem como a diversidade das equipes de trabalho sob sua responsabilidade. É papel do líder, construir elos entre as pessoas, independente da posição hierárquica e articular relações de trabalho com profissionais de todos os níveis (LOMBARDO, 2013). 
A Embrapa foi elogiada pela formação técnica de seus profissionais. No entanto, como foi indicado por várias fontes no decorrer da pesquisa, a fim de atingir elevados resultados na área de cooperação internacional, a instituição precisará investir na qualificação das suas próprias lideranças. Além disso, deverá buscar oportunidades de debates entre os parceiros externos e os próprios cooperantes embrapianos, a fim de gerar resultados significativos para todos os envolvidos.

Ainda que a ausência de uma estratégia sólida e de longo prazo faça parte de várias instâncias políticas, a Empresa deve consolidar sua forma de atuação. $\mathrm{O}$ contrário disso é manter-se reativo e atuar de forma periférica. Atualmente, conforme identificado nas entrevistas, e comparando documentos e discursos institucionais, o diálogo interno-externo permanece distante de suas normas e práxis.

A Embrapa, recentemente, atualizou seu site e tem criado maior interação nas redes sociais, porém seus canais de diálogo ainda são restritos até mesmo internamente. Enquanto se apregoa a busca por soluções compartilhadas e o princípio da horizontalidade na cooperação internacional, internamente as relações ainda são muito verticais.

Ao construir um planejamento estratégico participativo, pautado em mudanças essenciais na sua cultura organizacional, a Empresa ampliará suas oportunidades de atuar com um real intercâmbio de conhecimento e soluções compartilhadas. Os reflexos virão em modelos de gestão integrados, que incorporem o componente cultural; no aprendizado de escutar ativamente às reais demandas de seus interlocutores, e buscar soluções para garantir sua competitividade.

Foram apresentados pelos cooperantes alguns dos principais desafios percebidos no ProSavana-PI. Em função da conjuntura do Projeto, alguns deles foram bastante explorados e debatidos. Embora o momento político, caracterizado por incertezas, e a preocupação com a continuidade do Projeto, os entrevistados destacaram algumas oportunidades. Em particular, os cooperantes da Embrapa, $A B C$ e JICA destacaram a importância de "contribuir para o desenvolvimento agrícola" e o "aprendizado institucional e individual" como determinantes para consolidar novas iniciativas, além do ProSavana.

A Embrapa tem em sua experiência projetos de CTPD considerados bem sucedidos, assim como tem lições aprendidas, derivadas de alguns insucessos. Tais experiências podem gerar insumos para a sistematização de boas práticas necessárias para estruturar estratégias e práticas de cooperação técnica 
internacional que sejam e se mantenham coerentes com sua missão, visão, valores e diretrizes institucionais. Da mesma forma, seus documentos institucionais podem ser adaptados a fim de gerar coerência com os discursos de sua Diretoria Executiva.

Para além da Embrapa, é fundamental elucidar conceitos e valores de cooperação para diferentes países, trazendo à tona o que diferentes grupos entendem como "boas práticas" em cooperação internacional. Em Moçambique ou em qualquer outro país no qual se busque desenvolver uma aliança duradoura, é essencial a promoção de um diálogo coerente, reflexivo e maduro, sem as ilusões de uma relação perfeita, mas com a motivação para buscar as melhores alternativas para o crescimento e o respeito mútuo. Algumas recomendações foram indicadas pelos próprios cooperantes. Esse trabalho poderia ser ampliado e por meio da construção coletiva, agregar novas recomendações. 


\section{CONSIDERAÇÕES FINAIS}

Embora esse espaço seja destinando às conclusões, houve ao final de cada capítulo, a apresentação de comentários e considerações referentes à temática apresentada. Ao longo da dissertação, buscou-se a interação entre dados teóricos, empíricos e um delineamento lógico que foi construído durante a pesquisa, e, principalmente, a partir da interlocução com os cooperantes brasileiros.

De modo geral, a Cooperação Sul-Sul é percebida como uma oportunidade para que os diferentes atores envolvidos possam reconsiderar suas abordagens de atuação (PERCH; BRADLEY 2012). Sabe-se que várias instituições ao redor do mundo têm investido esforços na cooperação técnica internacional. Várias delas almejam atuar de forma comprometida e engajada, co-criando alternativas e soluções com os atores envolvidos. A grande dificuldade percebida, a partir da pesquisa documental, bibliográfica, entrevistas e análises realizadas, no que tange a CTPD, é que, embora haja boas intenções, aparenta-se por parte dos envolvidos um longo distanciamento entre "o que fazer" e "qual estratégia e abordagem adotar" para o alcance das metas planejadas.

Os dados institucionais apresentados são incontestáveis quanto à importância que a Embrapa assumiu no Brasil e nos países com os quais estabelece cooperação técnica, especialmente no âmbito das relações sul-sul. Sua trajetória evidencia a sua capacidade de moldar-se às novas situações políticas e necessidades econômicas. Por outro lado, a abordagem difusionista tem sido cada vez mais questionada. Atualmente, destaca-se nos discursos institucionais o desejo de mudar do modelo tradicional de transferência de tecnologia para abordagens mais modernas, que privilegiam o intercâmbio de conhecimento, a construção coletiva e maior diálogo com as comunidades envolvidas. Ter sensibilidade para respeitar e valorizar os saberes das comunidades tradicionais é dever da ciência. Para que se possa customizar o conjunto de oportunidades do intercâmbio de conhecimento é preciso entender a interação entre o ser humano e o ambiente à sua volta, bem como as relações interculturais entre os diversos atores envolvidos nas atividades de cooperação técnica internacional e suas diferentes concepções com relação ao escopo do seu trabalho. Também é preciso entender como as comunidades locais percebem o papel da Embrapa e a abordagem adotada em sua cooperação. 
Um elemento fundamental para determinar o modelo de cooperação para o desenvolvimento de um país é a clara compreensão de quais são as prioridades e limitações de seu povo. Um país como Moçambique pode não ter o mesmo modo de absorver as ideias progressistas do Brasil. Sua população pode ser favorável à cooperação e à modernização, por entender que proporcionam alguns avanços concretos, mas não necessariamente busca a mesma bagagem ideológica, ou adota os mesmos valores, padrões ou costumes do Brasil.

A percepção sobre modernidade e progresso pode ser diferente até dentro de uma mesma nação. Nas relações transnacionais, ganha novas dimensões. "A modernidade se tornou um projeto polêmico e suspeito - com essa mescla de memória heterogênea e inovações truncadas" (CANCLINI, 1997, p. 20). Sobrepor ao outro uma forma de pensar que implica outras linguagens, estruturas e abordagens desperta suas defesas ante aquele que ameaça romper aquilo que já é conhecido (FREIRE, 1977). "Os modernizadores conceberam [...] um saber pelo saber, sem fronteiras territoriais, e confiaram à experimentação e à inovação autônomas suas fantasias de progresso" (CANCLINI, 1997, p. 21). É preciso ampliar as reflexões sobre a relação ciência e sociedade e admitir que a atividade científica não é neutra, pois sofre a pressão de instrumentos institucionais e ideológicos criados e acionados para reproduzir o esquema da dominação dos segmentos hegemônicos da sociedade (AGUIAR, 1986). Deve-se buscar, portanto, a interpretação dos impactos da tecnologia moderna na interação com as tradições que persistem.

Os documentos técnicos da Embrapa que regulam a implementação do ProSavana indicam preocupações de ordem socioeconômica. Segundo os discursos, existe empenho das instituições envolvidas com a CTPD em agricultura, de modo geral, e da Embrapa, em particular, de promover maior diálogo com a sociedade. Não obstante, no caso específico do ProSavana, as críticas tanto internas quanto externas apontam para respostas comuns, direcionando para uma implementação inadequada. Um estudo acadêmico recente indica que "sem uma relação de horizontalidade e reciprocidade, o ProSAVANA enfrenta desafios internos e externos, sendo o embate com a sociedade civil um ponto de atenção sobre a sua continuidade" (FINGERMAN, 2014, p. 25). Desse modo, um diálogo mais crítico e inclusivo sobre como maximizar os recursos naturais, sociais e culturais pode ser a fonte para a cooperação em amplas dimensões. 
O governo moçambicano precisa desenvolver o setor agrícola, de forma integrada, ou seja, com a inserção da sociedade civil em suas políticas e na priorização dos planos. De certo modo, o Brasil não percebeu claramente essa necessidade, ao desenvolver sua cooperação com Moçambique sem promover a plena participação da sociedade local. Acreditou-se que, ao proceder de acordo com os planos construídos de forma coletiva pela Minag, seriam contempladas as demandas e necessidades da sociedade civil de Moçambique. Com esta convicção, o grupo coordenado pelo Brasil, Japão e Moçambique apostou em construir um Plano de Comunicação e em envolver profissionais moçambicanos para sua execução local. Houve uma tentativa de vencer os desafios, extrair lições e buscar as melhorias ao longo do projeto.

A Cooperação Sul-Sul brasileira, atualmente, não envolve participação expressiva da sociedade civil. Uma abordagem mais inclusiva que gere propostas e decisões compartilhadas fortaleceria a interação dos vários atores envolvidos, conferindo ao Estado maior legitimidade em sua atuação. Sabe-se que tanto o Brasil quanto seus parceiros ainda podem e devem fazer mais para promover maior participação da sociedade civil nas iniciativas de cooperação técnica internacional. É premente desenvolver uma estratégia que possibilite maior integração e interação social entre as diferentes nações, gerando diálogos sinergéticos.

$\mathrm{Na}$ realidade, muitos dos problemas enfrentados no que se refere às tensões com as organizações não governamentais poderiam ter sido antecipados e trabalhados, se desde o princípio a abordagem de atuação fosse amplamente participativa. Nesse sentido, a maioria dos informantes internos ou externos apontou falta de transparência e comunicação nos mais diferentes níveis. Conforme colocado pelos entrevistados, é extremamente importante entender a demanda, e levantar as expectativas. No entanto, assim como eles próprios constataram, o que diz o governo moçambicano, não necessariamente é o que se ouve em diferentes grupos da sociedade local. Há um conflito entre diferentes forças e um jogo de poder que ameaça, ao mesmo tempo em que oportuniza um crescimento no modelo de cooperação brasileiro, pois amplia sua visão da realidade.

A ampliação do diálogo, considerando as culturas dos diferentes atores, possibilita perceber a visão do todo e reduz os juízos de valor, os dogmatismos ingênuos, as interpretações equivocadas. A visão de cada parte não pode ser unidirecional, visto que é preciso compreender seu significado cultural para os 
beneficiários, recipiendários e parceiros. No ProSavana, segundo os próprios cooperantes, a percepção da necessidade de aumentar a comunicação ocorreu ao longo do Programa, diante das reações contrárias ao posicionamento estabelecido.

$O$ estudo ainda enfatiza que a contraparte brasileira foi afetada pelos cortes orçamentários sofridos pela ABC durante o governo da Presidente Dilma Roussef, que, de certo modo, afetaram o desenvolvimento da cooperação entre Brasil, Moçambique e Japão. Fica claro pelas vozes dos cooperantes que esse corte trouxe consequências drásticas ao projeto e frustrou as partes envolvidas. Apesar dessas circunstâncias, os técnicos da Embrapa envolvidos na implementação local do projeto demonstraram solidariedade e profissionalismo ao manter continuidade em seus trabalhos junto aos técnicos do IIAM. Mas, de modo mais amplo, as limitações orçamentárias geraram desconfiança em diferentes instâncias. Além disso, o trabalho que se espera da Embrapa é um trabalho técnico, profissional e não assistencialista, embasado no sacrifício de seus técnicos.

A participação de empresas brasileiras em várias obras e investimentos no Corredor de Nacala deixa pouco claro o que, realmente, se espera da CTPD brasileira. O ProSavana visa promover a segurança alimentar através de uma melhoria da produtividade agrícola, mas ao mesmo tempo, envolve importantes investimentos privados. Empresas de consultoria que costumam trabalhar para grandes investidores do setor privado participaram da concepção do ProSavana e empresas privadas de vários setores de negócios estão envolvidas em sua implementação. A Fundação Getúlio Vargas (FGV), projetou o plano-mestre de empresa e criou um fundo privado para atrair investidores e as empresas brasileiras: Vale, Petrobrás e Odebrecht, entre outras, têm grandes investimentos em Moçambique. Obviamente, essa composição de fatores implica uma forte relação com a atual abordagem brasileira no ProSavana (STEINER, 2014). Ao mesmo tempo, enquanto busca implantar um corredor de produção de commodities com agricultura de alta tecnologia, desconsidera as dificuldades educacionais dos técnicos. São posicionamentos contraditórios. Uma visão mais ampla permitiria observar que todas essas relações se entrelaçam umas com as outras e se potencializam, gerando interferências.

Diante do exposto, cabe ressaltar que para atuar com um novo modelo de transferência de tecnologia voltado para o intercâmbio de ideias, é preciso construir um diálogo intercultural. Nesse sentido, é determinante investigar a cultura dos 
países com os quais a Embrapa se relaciona em cooperação técnica internacional e pesquisar a partir de suas próprias vozes como esse diálogo deve ser construído. Essa colocação ficou bem fundamentada pelos entrevistados quando defenderam a necessidade de levantar demandas e expectativas.

As instituições que atuam com CTPD tendem a manter uma abordagem difusionista e de transferência de tecnologia verticalizada, sem considerar aspectos e dinâmicas determinantes de ordem cultural. De acordo com os depoimentos dos informantes, não se atentar para as referências das comunidades locais, seus valores, crenças e modos de vida, dificulta o intercâmbio de conhecimentos e experiências entre países. Seria superficial uma metodologia, um modelo, uma abordagem que se satisfizesse com a primeira impressão ou, simplesmente, com o mensurável. Busca-se uma atuação crítica e autocrítica, como requer a dinâmica da realidade social (DEMO, 1985).

Ao longo dos anos, o modelo de cooperação triangular tem se ampliado, inclusive em razão do estabelecimento de redes e de parcerias institucionais entre os países envolvidos. Ao mesmo tempo, o aprofundamento do diálogo com os países "beneficiários" tem demandado mecanismos cada vez mais eficientes de coordenação e comunicação entre os parceiros do Brasil. Portanto, recomenda-se analisar, de forma mais aprofundada, como tais dinâmicas interculturais e territoriais, são impactadas pela implementação de projetos de cooperação técnica da Embrapa. Afinal, elas podem ser determinantes para promover novos modos de vida das populações envolvidas e novas relações entre sociedade e estados, mercados e meio ambiente nos países onde a Embrapa executa projetos de cooperação técnica internacional. Novas investigações poderão contribuir para a modificação e construção de novos contextos socioeconômicos e políticos, que apoiem a inserção de agricultores e comunidades tradicionais nos mercados locais, regionais e globais, aprimorando a organização da sua produção agrícola de forma sustentável.

Como apontado por um informante, nem todo problema dos projetos de cooperação diz respeito a questões de relacionamento intercultural: alguns problemas são apenas de ordem interpessoal entre as lideranças envolvidas nos processos de gestão e implementação dos projetos. Na verdade, percebe-se que existe uma teia complexa de interações, na qual as mutáveis dinâmicas políticas alteram o encaminhamento de um projeto. 
As negociações são constantes, e os cooperantes ainda que enfrentem desafios e sacrifícios não parecem arrependidos de suas experiências. A equipe técnica (principalmente os líderes de projeto da Embrapa) reconheceu problemas e forças externas ao projeto, mas não foi afetada significativamente por elas. Os técnicos focam-se no trabalho, envolvem-se com suas rotinas, relacionam-se naquele ambiente institucional e tentam dar sua contribuição. Suas preocupações maiores são se a semente chegou a tempo ou se o corte de recursos vai afetar a construção de um laboratório. Acaba sendo menos importante saber se empresas brasileiras estão lucrando com seus negócios de forma ética no Corredor de Nacala. Soma-se a isso que um cooperante brasileiro, de modo geral, entende o progresso de forma diferente do moçambicano comum. A valorização da agricultura familiar, no Brasil, é defendida em pequenos nichos. Prevalece a preocupação com uma agricultura de larga escala.

O que se percebe é que independente do modelo de cooperação adotado e das políticas governamentais, as relações entre Brasil e Moçambique, potencialmente, continuarão ocorrendo. Pode ser que a Embrapa continue sendo protagonista no que tange a pesquisa e a transferência de tecnologia. Da mesma forma, a presença de novos atores pode reduzir sua atuação. De toda forma, o papel da Embrapa na cooperação internacional deve ser bem construído para permanecer relevante. Não pode depender da abordagem de cada líder de projeto, mas ter identidade institucional, baseada no seu histórico de trabalho em agricultura com o Japão, com países africanos e outros com os quais se relaciona. Ainda que os projetos da Embrapa busquem atuar de forma a dialogar com as comunidades, seu desempenho pode ficar ameaçado pela ausência de horizonte estratégico e da consolidação entre as melhores práticas de interação com as comunidades moçambicanas. Cabe à Empresa manter uma trajetória de inovação em agricultura, ser integradora de pessoas, políticas e instituições e catalisadora de mudanças estruturais. Nesse sentido, é essencial que todos os atores envolvidos em projetos de cooperação técnica internacional, principalmente aqueles do Governo Brasileiro, busquem uma atuação mais estratégica, integrada e sinergética junto aos governos dos países parceiros. 


\section{REFERÊNCIAS}

A EMBRAPA e o mundo: parcerias no Brasil e no exterior em 2007: mais resultados para ciência e benefícios para a população. GeneBio:Informativo da Embrapa Recursos GenétBicos e Biotecnologia, Brasília, ano V, n. 14, p. 6-7, out. 2007.

ABC. Agência Brasileira de Cooperação. 2012. Disponível em: <http://www.abc.gov.br/imprensa/mostrarnoticia/105>. Acesso em: 13 maio 2014.

Agência Brasileira de Cooperação: Diálogo Brasil-África em Segurança Alimentar, Combate à Fome e Desenvolvimento Rural. Brasília, 2011.

. Programa de Treinamento para Terceiros Países - TCTP. S.d. Disponível em: <http://www.abc.gov.br/treinamentos/informacoes/oqueetctp.aspx>. Acesso em: 22 maio 2014.

A cooperação técnica brasileira: agricultura, segurança alimentar e políticas sociais. Brasília, 2011.

ABRAMOVAY, R. Agriculttura familiar e serviço público. Cadernos de Ciência e Tecnologia, v. 15, n. 1, 137-157, jan./abr. de 1998.

. Desenvolvimento sustentável: qual é a estratégia para o Brasil? Novos Estudos, v. 87, p. 97-113, 2010.

AGUIAR, R. C. Abrindo o pacote tecnológico: Estado e pesquisa agropecuária no Brasil. São Paulo: Pólis, 1986.

ALMEIDA, C.; CAMPOS, R. P. A concepção brasileira de "cooperação Sul-Sul estruturante. RECIIS - R. Eletr. de Com. Inf. Inov. Saúde, v. 4, n. 1, p. 25-35, 2010.

ALVES, E.; et al. Fatos marcantes da agricultura brasileira. In: ALVES, E.; SOUZA, G; GOMES, E. (Ed.). Contribuição da Embrapa para o desenvolvimento da agricultura no Brasil. Brasília: Embrapa, 2013.p. 13-45.

ANGROSINO, M. Etnografia e observação participante. São Paulo: Artmed, 2008.

BADI, M. Integración regional en África: obstáculos y alternativas. Nova Africa, v. 25, 91-112, 2009.

BID; OCDE. Banco Africano de Desenvolvimento, Organização para a Cooperação e Desenvolvimento. Perspectivas Econômicas em África 2013: transformação estrutural e recursos naturais, 2013. Disponível em: <http://www.oecdilibrary.org/perspectivas-economicas-em-africa-2013-versaocondensada 5k49hlsamg0w.pdf;jsessionid $=18 \mathrm{hfe} 6 \mathrm{fjuataa} . \mathrm{x}$-oecd-live02?contentType =\%2fns\%2fOECDBook\%2c\%2fns\%2fBook\&itemld=\%2fcontent\%2fb ook\%2f9789264200562-

pt\&mimeType=application\%2fpdf\&containerltemld=\%2fcontent\%2fbook\%2f9789264 200562-pt\&accessltemlds=>. Acesso: 10 mar 2015 
BARROS, F. L. Accountability de agências financeiras de cooperação multilateral: os casos do BM e do BID e seus desdobramentos no Brasil. In: SILVA, K.; SIMIÃO, D. Timor Leste por trás do palco: cooperação internacional e a dialética da formação do Estado. Belo Horizonte: UFMG, 2007. p. 300-320.

BHABHA, H. K. O local da cultura. Belo Horizonte, MG, Brasil: UFMG, 1998.

BONI, V.; QUARESMA, S. Aprendendo a entrevistar: como fazer entrevistas em Ciências Sociais. Em Tese: Revista Eletrônica dos Pós-Graduandos, v. 2, p. 6880, 2005.

BRASIL. Decreto no 7.766, de 25 de junho de 2012. Aprova o Estatuto da Empresa Brasileira de Pesquisa Agropecuária - EMBRAPA. Diário Oficial da União, Brasília, DF, 26 jun. 2012. Seção 1, p. 10.

CABRAL, J. Sol da manhã: memória da Embrapa. Brasília: UNESCO, 2005.

CABRAL, L. Cooperação Brasil-África para o desenvolvimento: Caracterização, tendências e desafios. Textos Cindes, n. 26, 26 dez. 2011.

- Multipolaridade hegemônica?: cenários para a cooperação para o desenvolvimento internacional e implicações para o Brasil. Breves Cindes, n. 79, dez. 2013.

CABRAL, L. et al. Brazil-Africa: Agricultural Cooperation Encounters: Drivers, Narratives and Imaginaries os Africa and Development. IDS Bulletin, 44, jul. 2013.

CABRAL, L.; et al. J. Mozambique's Agriculture and Brazil's Cerrado'model': Miracle or Mirage? GREAT Insights, v. 1, n. 10, 2012. p. 17-18.

CAMPOS, R.P. A cooperação técnica brasileira entre países em desenvolvimento: limites e perspectivas da política externa nacional. In: SILVA, K.; SIMIÃO, D. TimorLeste por trás do palco: cooperação internacional e a dialética da formação do Estado. Belo Horizonte: UFMG, 2007.p. 343-364.

CANCLINI, N. A globalização imaginada. São Paulo: Iluminuras, 2003.

CESARINO, L. Antropologia multissituada e a questão da escala: reflexões com base no estudo da cooperação sul-sul brasileira. Horizontes Antropológicos, p. 1950, jan./jun. 2014.

CHANG, H. J. 23 coisas que não nos contaram sobre o capitalismo. São Paulo: Cultrix, 2013.

CLASSEN, S. Análise do discurso e dos antecedentes do Programa ProSAVANA em Moçambique: enfoque no papel do Japão. Tokyo University of Foreign Studies: Tóquio, 2013. No prelo. Disponível em: < http://www.open.ac.uk/technology/mozambique/sites/www.open.ac.uk.technology.mo zambique/files/files/An\%C3\%A1lise\%20do\%20Discurso\%20do\%20ProSAVANA\%20 \%28Funada\%29.pdf>. Acesso: 10 abr. 2015. 
CONTINI, E.; MARTHA JÚNIOR, G. Desenvolvimento da agricultura na África: Brasil, um bom parceiro? Brasília, 2013.No prelo.

CÔRREA, M. A prática comentada da cooperação internacional: entre a hegemonia e a busca da autonomia. Brasília: [s.n.], 2010.

CORREA, P.; SCHMIDT, C. Public Research Organizations and Agricultural Development in Brazil: How did Embrapa get it right? Economic Premise, v. 145, June $2014 . \quad$ p.1-10. Disponível em: http://siteresources.worldbank.org/EXTPREMNET/Resources/EP145.pdf. Acesso: 10 Mai 2015.

COZBY, P. Métodos de pesquisa em ciências do comportamento. São Paulo: Atlas, 2003.

DA MATA, R. O ofício do etnólogo, ou como Ter "Anthropological Blues". In: NUNES, Edson (org.). A aventura sociológica. Rio de Janeiro: Zahar, 1978.

DE RENZIO, P.; et al. A. O Brasil e a Cooperação Sul-Sul: Como Responder aos Desafios Correntes. Policy Brief, maio de 2013. Disponível em: < bricspolicycenter.org/homolog/uploads/trabalhos/5992/doc/1619030609.pdf >. Acesso em 10 Mai 2015.

DEMO, P. Introdução à metodologia da ciência. São Paulo: Atlas, 1985.

DENZIN, N.; LINCOLN, Y. O planejamento da pesquisa qualitativa: teorias e abordagens. Porto Alegre: Artmed, 2006.

EMBRAPA. Departamento de Transferência de Tecnologia (DTT). Anais dos Encontros Regionais sobre Difusão de Tecnologia. Brasília: Embrapa, 1990.

Departamento de Transferência de Tecnologia (DTT). Relatório interno: fundamentos sobre a interação entre a Embrapa e a sociedade: transferência de tecnologia, intercâmbio e construção de conhecimento. Brasília, 2015.

. Plataforma África-Brasil de Inovação Agropecuária: resenha da primeira fase. Brasília: EMBRAPA, 2011.

Projeto de melhoria da capacidade de pesquisa e de transferência de tecnologia para o desenvolvimento da agricultura no Corredor de Nacala em Moçambique. Brasília: Embrapa SRI, 2011.

. Informações SRI relatórios de atividades - 2012: ações da Embrapa no exterior. Brasília, 2013. Relatório de Atividades.

Cooperação Técnica. 2014g. Disponível em Embrapa <https://www.embrapa.br/cooperacao-tecnicas. Acesso em: 8 out. 2014.

Embrapa Marketplace. 2014e. Disponível em <https://www.embrapa.br/marketplace >. Acesso em: 15 maio 2014. 
. Informações para a elaboração do Relatório Anual 2013: atuação internacional. Brasília, 2014c. (Relatório de Atividades).

. Portal Embrapa: ProSavana. 2014b. Disponível em:

<https://www.embrapa.br/prosavana>. Acesso em: 05 abr. 2014.

. Projetos estruturantes. 2014d. Disponível em:

<https://www.embrapa.br/projetos-estruturantes>. Acesso em: 05 abr. 2014.

. Segurança alimentar. 2014f. Disponível em:

<https://www.embrapa.br/seguranca-alimentar-em-mocambique>. Acesso em: 05 abr. 2014.

EMBRAPA. Visão 2014-2034: o futuro do desenvolvimento tecnológico da agricultura brasileira. Brasília, 2014a.

EMBRAPA. Secretaria de Gestão Estratégica. V Plano Diretor da EMBRAPA (2008-2011-2023). Brasília: Embrapa, 2008.

EMBRAPA. Secretaria de Relações Internacionais (SRI). II Reunião de Coordenação para início das atividades previstas no Plano Anual de Trabalho Conjunto (Work Plan I)". Brasília, 2011c.

EMBRAPA ESTUDOS E CAPACITAÇÃO. (Cecat). Embrapa estudos e capacitação. Disponível em: <http://cecat.embrapa.br>. Acesso em: 21 maio 2014.

EMBRAPA INFORMAÇÃO TECNOLÓGICA. Sugestões para formulação de um Sistema Nacional de Pesquisa Agropecuária. Brasília, DF, 2006.

EMBRAPA MONITORAMENTO POR SATÉLITE. Paralelos: Corredor de Nacala. Campinas, 2010.

ESTARQUE, M. Projeto brasileiro que inspirou o ProSavana teve impactos ambientais graves. DW, 30 ago. 2013. Disponível em: <www.dw.de/projetobrasileiro-que-inspirou-o-prosavana>. Acesso em: 24 ago. 2014.

FELLET, J. Embrapa está revendo presença na África, diz presidente. BBC Brasil. Disponível <http://www.bbc.co.uk/portuguese/noticias/2013/02/130122_embrapa_entrevista_2_j f_cc.shtml>. Acesso em: 04 jun. 2014.

FINGERMANN, N. N. Os mitos por trás do ProSavana. IESE, Maputo, 29 de maio de 2013.

A Cooperação trilateral Brasileira em Moçambique: um estudo de caso comparado: o ProALIMENTOS e o ProSAVANA. São Paulo, SP, 2014.

FREIRE, P. Extensão ou comunicação? Rio de Janeiro: Paz e Terra, 1977.

GALPER, J. Política social e trabalho social. São Paulo: Cortez, 1986. 
GASTAL, M. L. Pesquisa com e para os agricultores familiares e as comunidades tradicionais. In: EMBRAPA. Transferência de tecnologia e construção do conhecimento . Brasília: Embrapa, 2013. p. 33-55.

HALBWACHS, M. A memória coletiva. São Paulo: Edições Vértice. Editora Revista dos Tribunais, 1950

HALL, S. Da diáspora: identidades e mediações culturais. Belo Horizonte: Ed. UFMG, 2003.

IPEA; ABC. Cooperação brasileira para o desenvolvimento internacional: 2010. Brasília: Ipea, 2013.

IPEA; BANCO MUNDIAL. Ponte sobre o Atlântico Brasil e África Subsaariana: parceria Sul-Sul para o crescimento. Brasília: Ed. Ipea e Banco Mundial, 2011.

IZIQUE, C. O PAC da Embrapa: inovação. Pesquisa Fapesp, v. 144, 2008.

KEOHANE, R. After hegemony: cooperation and discord in the world political economy. Princetown: Princetown University, 1984.

LABACHE, L.; SAINT MARTIN, M. Fronteiras, trajetórias e experiências de rupturas . Educ. Soc., Campinas, v. 29, n. 103, p. 333-354, maio/ago. 2008.

LEITE, I. Cooperação Sul-Sul: conceito, história e marcos interpretativos. Observador On-line, Rio de Janeiro, v. 7, 2012.

LISITA, F.O. Considerações sobre a extensão rural no Brasil: a extensão rural no Brasil nasceu sob o comando do capital, com forte influência norte-americana e visava superar o atraso na agricultura. Ambiente Brasil. S.d. Disponível em: $<$ http://ambientes.ambientebrasil.com.br/agropecuario/artigo agropecuario/considera coes sobre a extensao rural no brasil.html>. Acesso: 10 mar 2015.

LOMBARDO, A. Coaching Transcultural: uma nova metodologia para antecipar e gerenciar mudanças individuais e organizacionais. In: PÉRCIA, A.; et al.. Master Coaches; técnicas e relatos de mestres do coaching. São Paulo, Ed. Ser Mais, 2012, p. 11-18.

Coaching para retenção de talentos: uma estratégia essencial de vantagem competitiva para organizações globais. In: PÉRCIA, A.; SITTA, M. Coaching: grandes mestres ensinam como estabelecer $e$ alcançar resultados extraordinários na sua vida pessoal e profissional. São Paulo: Ed. Ser Mais, 2012, p. 17-24.

LOMBARDO, A.; VALENTE, A.L.E.F. Hibridismo cultural: ameaças e oportunidades para o desenvolvimento da África do Sul. Revista USP. No prelo.

LOPES, J. D. O Senhor das Moscas: os labirintos do poder e da violência numa antropologia da cultura. In: TEIXEIRA, I. A.; LOPES, J. D. A diversidade cultural vai ao cinema. Belo Horizonte: Autêntica, 2006. p. 65-88. 
MALINOWSKI, B. Os Argonautas do Pacífico Ocidental. In: Ethnologia, n.s, n. 6-8, p. 17-37, 1997.

MBEMBE, A. As formas africanas de auto-inscrição. Estudos Afro-Asiáticos, v. 1, p. 171-209, 2001.

MILANI, C. R. Evolução histórica da cooperação norte-sul. In: IPEA. Repensando a cooperação internacional para o desenvolvimento. Brasília: Ipea, 2014. p. 33-56.

MILANI, C. R.; CARVALHO, T. Cooperação Sul-Sul e política externa: Brasil e China no continente africano. Estudos Internacionais, v. 1, n. 1, p. 11-35, jan. jun. 2013.

MINAYO, M. O desafio do conhecimento: pesquisa qualitativa em saúde. Rio de Janeiro: Abrasco, 2007.

MOYO, DAMBISA. Dead Aid: why aid is not working and how there is another way for Africa. England: Allen Lane, 2009

BRASIL. Ministério das Relações Exteriores. Cooperação técnica. S.d. Disponível em: <http://www.itamaraty.gov.br/temas/cooperacao-tecnica>. Acesso em: 08 de out. 2014.

MORAIS, I. ProSAVANA e os riscos omitidos da produção sob contrato. Lisboa: Escolar Ed., 2014.

MUNDIMBE, V. The invention of Africa: gnosis, philosophy, and the order of knowledge. Indiana University, 1998.

MUSSOI, E. Integración entre investigación y extensión agraria en un contexto de descentralización del Tese: Estado y sustentabilización de políticas de desarrollo: el caso de Santa Catarina, Brasil. 1998. 420 f.Tese (Doutorado) Universidad de. Córdoba, Espanha, 1998.

NOGUEIRA, I. ProSAVANA e os riscos omitidos da produção sob contrato. Observador Rural, 15, 2014.

NOGUEIRA, I.; OLINAHO, O. From Rhetoric to Practice in South-South Development Cooperation: A case study of Brazilian interventions in the Nacala corridor development program. Geneva: Institute of Socioeconomics University of Geneva, 2013.

ONU. Charter of United Nations. Disponível em: <http://www.un.org/en/documents/charter/chapter1.shtml>. Acesso em: $1^{\circ}$ jan. 2015

OSMAN, A. M.; SAÚTE, N. Moçambique no mundo: a competição subtil. In: L. d. BRITO, C. N. CASTEL- BRANCO; S. CHICHAVA; A. FRANCISCO, Desafios para Moçambique 2010. Maputo: IESE, 2010.

PAIVA, F. ProSavana: críticas e esclarecimentos. Agroanalysis, abr. 2013. Disponível em: <http://www.agroanalysis.com.br/edicao indice.php?idEdicao=83 >. Acesso: 10 mar 2015. 
PEIXOTO, M. Extensão rural no Brasil: uma abordagem histórica da legislação.

Textos para Discussão, v. 48, 2008. Disponível em: < http://www12.senado.gov.br/publicacoes/estudos-legislativos/tipos-de-

estudos/textos-para-discussao/td-48-extensao-rural-no-brasil-uma-abordagem-

historica-da-legislacao >. Acesso: 10 mar. 2015.

PERCH, L.; BRADLEY, D. Overview: Agricultural Futures and the Role of SouthSouth Cooperation. Poverty in Focus, v. 24, n. 43, 2012, p.3-5.

PINO, B. A.; LEITE, I. C. O Brasil e a Cooperação Sul-Sul: contribuições. Meridiano, 47, n. 113, p. 17-18, dez. 2009.

PNUD. Cooperação Sul-Sul. 2012. Disponível em: <http://www.pnud.org.br/CooperacaoSulSul.aspx>. Acesso: 24 mai. 2014.

Relatório do desenvolvimento 2013: a ascensão do Sul - progresso humano num mundo diversificado. New York: Programa das Nações Unidas para o Desenvolvimento, 2013.

Relatório do desenvolvimento humano 2014: Sustentando o Progresso Humano: Redução da Vulnerabilidade e Construção da Resiliência. Disponível em: <http://www.pnud.org.br/atlas/ranking/Ranking-IDH-Global-2013.asp>. Acesso: 24 jan. 2015.

PUENTE, C. A cooperação técnica horizontal brasileira como instrumento da política externa: a evolução da cooperação técnica com países em desenvolvimento. Brasília: FUNAG, 2010.

RICHARDSON, R. J. et al. Pesquisa social: métodos e técnicas. São Paulo: Atlas, 1999.

RIGAMONTI, M.; SANTOS, J.; SOUZA, H. R. Alternância: uma educação para o desenvolvimento rural sustentável. In: BALSADI, O. et al. (Ed.). Transferência de tecnologia e construção do conhecimento. Brasília: Embrapa, 2013. p. 305-314.

RODRIGUES, W.; VASCONCELOS, S. J.; BARBIERO. A. Análise da efetividade socioeconômica do Prodecer III no município de Pedro Afonso, Tocantins. Pesquisa Agropecuária Tropical, v. 39, n. 4, p. 301-306, out./dez. de 2009.

SALLES-FILHO, S.; BIN, A. Reflexões sobre os rumos da pesquisa agrícola. In: BUAINAIN, A.M; ALVES,et al. (Ed.). Reflexões sobre os rumos da pesquisa agrícola: a formação de um novo padrão agrário e agrícola. Brasília: Embrapa, 2014. p. 423-454.

SAMPIERE, R.; COLLADO, C.; LUCIO, P. Metodologia de pesquisa. São Paulo: MCGraw-Hill Interamericana do Brasil, 2006.

SCHLESINGER, S. Cooperação e investimentos do Brasil na África: o caso do ProSavana em Moçambique. Maputo: FASE, 2013.

SEVERINO, A. Metodologia do trabalho científico. São Paulo: Cortez, 2007. 
SILVA, J. da. Agricultura familiar e inovação paradigmática na pesquisa agropecuária: contexto, interação e ética para a pesquisa social. In: SOUSA, I. S.; CABRAL, J. R. Ciência como instrumento de inclusão social. Brasília: Embrapa Informação Tecnológica, 2009. p. 329-386.

SILVA, K. C.; SIMIÃO, D. S. Timor Leste por trás do palco, um prólogo. In: SILVA, K. da; SIMIÃO, D. S. Timor-Leste por trás do palco: cooperação internacional e a dialética da formação do Estado. Belo Horizonte: Ed. UFMG, 2007. p. 11-24.

SIMIONE, A. A modernização da gestão e a governança no setor público em Moçambique. Revista de Administração Pública - RAP, Rio de Janeiro, v. 48, n. 3, 2014.

SOTILLO, J. Á. El sistema de cooperación para el desarrollo: actores, formas y processos. Madrid: Catarata, 2011.

SOUSA, I. S.; CABRAL, J. R. Ciência e inclusão social na agricultura. In: SOUSA, I. S.; CABRAL, J. R. Ciência como instrumento de inclusão social. Brasília: Embrapa Informação Tecnológica, 2009. p. 21-69.

SOUZA, A. M. Repensando a cooperação internacional para o desenvolvimento. In: IPEA. Repensando a cooperação internacional para o desenvolvimento. Brasília: Ipea, 2014. p. 11-29.

THOMPSON, P. A voz do passado: história oral. Rio de Janeiro: Paz e Terra, 1992.

TROMPENAARS, F. Resolving international conflict: culture and business strategy. London Business School, v. 7, n. 3, p. 51-88, 1996.

UCHOA, P. Aposta do Brasil na África esbarra em concorrentes e críticas. BBC Brasil. <http://www.bbc.co.uk/portuguese/noticias/2010/09/100831_eleicoes_africabre_ji.sht ml>. Acesso : 24 mai. 2014.

UNESCO. Relatório Mundial da UNESCO: investir na diversidade cultural e no diálogo intercultural. Brasília: 2009.

VALENTE, A. L. E. F. Como a cultura do "outro" pode ser arma na guerra. In: TEIXEIRA, I. A.; LOPES, J. D.(Org.) A diversidade cultural vai ao cinema. Belo Horizonte: Autêntica Ed., 2006. p. 89-104.

Diversidade, cultura e educação: conhecimentos antropológicos nos parâmetros curriculares nacionais: para uma discussão sobre a pluralidade cultural. In: GUSMÃO, N.M.M. (Org.) Diversidade, cultura e educação, São Paulo: Biruta, 2003.

Política e relações raciais: os negros e as eleições paulistas de 1982. São Paulo: FFLCH/USP, 1986.

VALENTE, A. L. E. F. et al. O papel da Embrapa na Cooperação Técnica Internacional para o Desenvolvimento Sustentável da África Subsaariana. In 
OTERO, M. R; et al.., Agricultura e desenvolvimento rural sustentável: desafios da cooperação técnica internacional. Brasília, IICA, 2015, p. $345-379$.

VIEIRA FILHO, J.E.R.Transformação histórica e padrões tecnológicos da agricultura brasileira. In: BUAINAIN, A.M. et al. (Ed.). O mundo rural no Brasil do século 21: A formação de um novo padrão agrário e agrícola Brasília: Brasília: EMBRAPA, 2014. p. 395-422.

YIN, R. K. Estudo de caso: planejamento e métodos. São Paulo: Bookman, 2001. 